VIVIEN THOMSON

\title{
CERTIFICATION AND REGULATION OF TRADE IN BIOFUELS
}

\author{
LLM DISSERTATION \\ LAWS 592: LLM BY DISSERTATION
}

FACULTY OF LAW

TE WHARE WĀNANGa O TE ŨPOKO O TE IKA A MĀUI

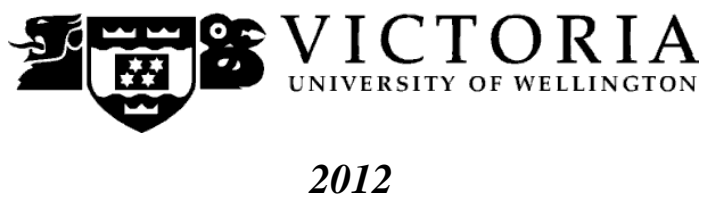




\section{Table of Contents}

I INTRODUCTION

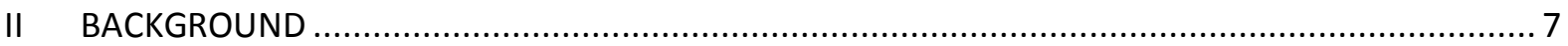

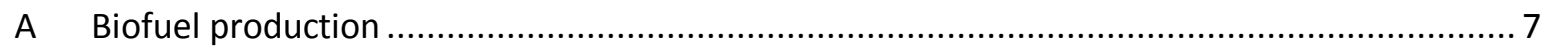

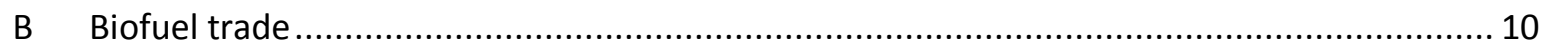

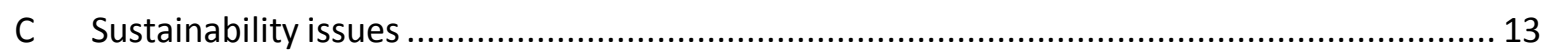

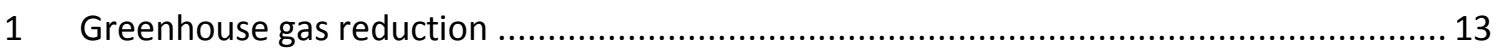

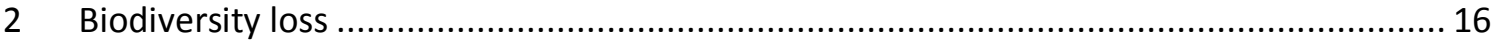

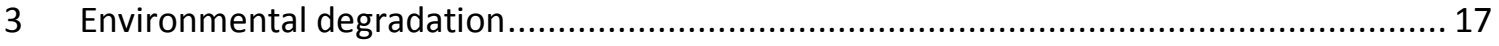

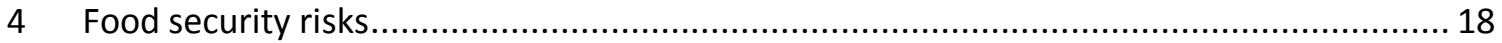

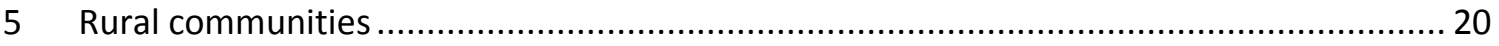

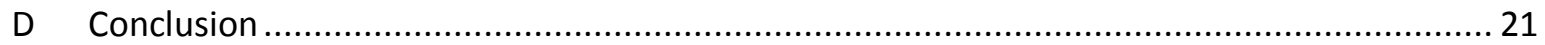

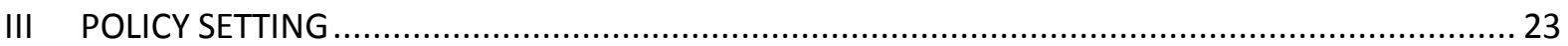

A Government support for research and production of environmentally sustainable biofuels. 24

1 Current policies relating to production of second generation biofuels .............................. 25

2 Current policies relating to tariffs and subsidies for biofuels............................................ 26

B Certification schemes for the sustainable production of biofuels...................................... 28

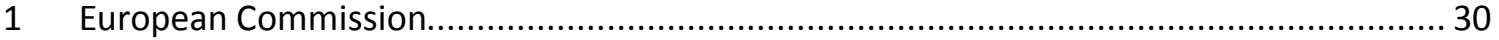

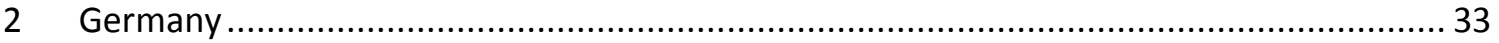

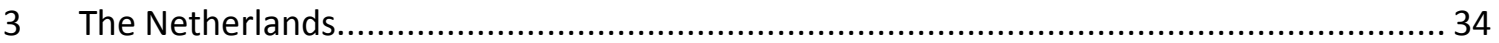

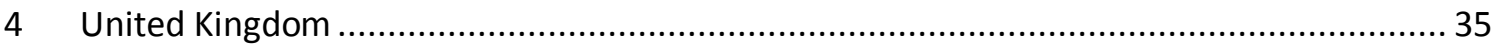

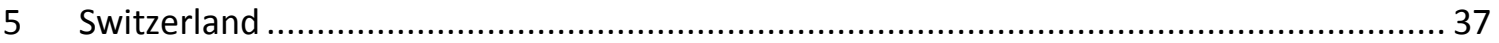

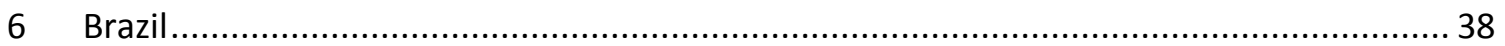

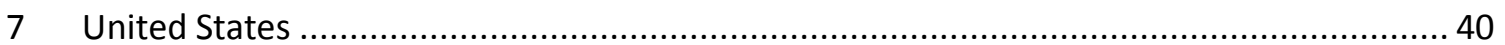

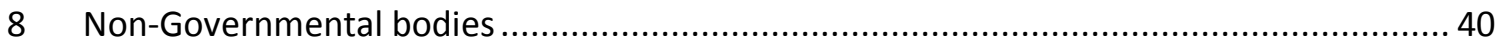

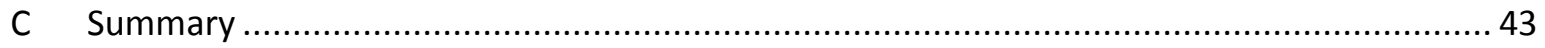

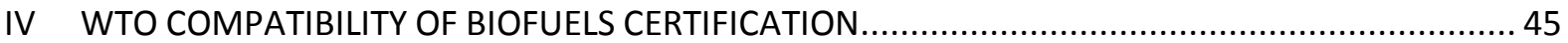

A Scope of WTO Agreements in governing biofuel certification schemes............................... 47

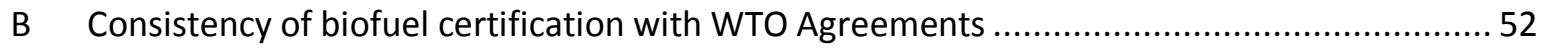

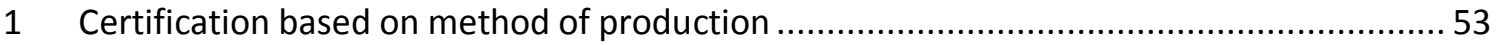

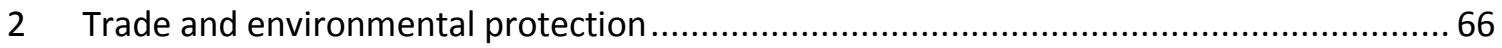




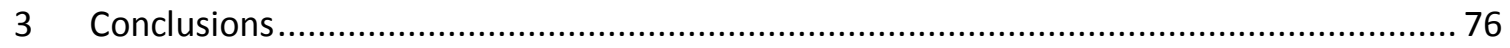

$\checkmark \quad$ THE USE OF INTERNATIONAL STANDARDS IN BIOFUEL CERTIFICATION.................................. 79

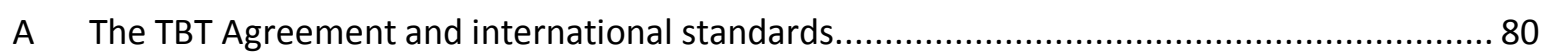

1 Recognition of a standard as an "international standard" ............................................... 81

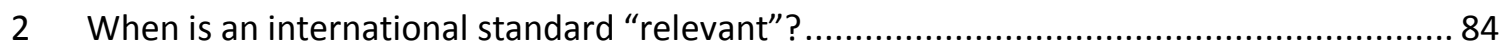

3 Determination of when an international standard is used "as a basis for" a measure ....... 85

4 Circumstances where a relevant international standard need not be used - burden of

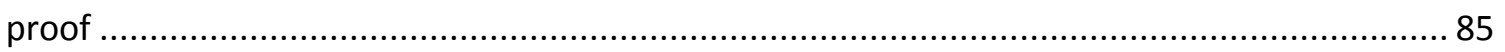

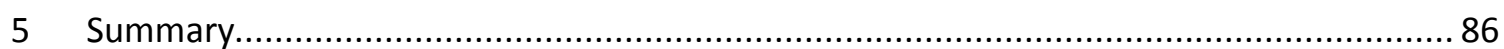

B Analysis of certification schemes and relevant international agreements............................ 87

1 Relevant international agreements relating to greenhouse gas emissions ....................... 87

2 International agreements relating to conservation of biodiversity .................................. 93

3 International agreements relating to other environmental concerns ............................... 98

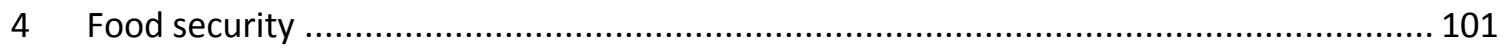

5 International agreements relating to labour and social conditions................................ 102

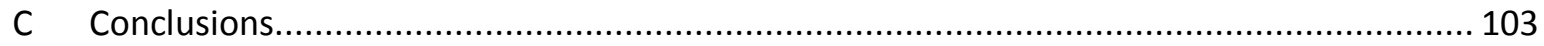

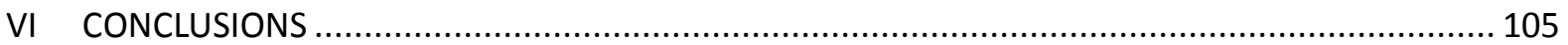




\begin{abstract}
The recent increase in biofuel production and trade has raised concerns about environmental and other impacts, and has prompted some governments to initiate measures to ensure biofuels are produced sustainably. Certification schemes are the most common measure used, and apply to both imported biofuels, and those produced in the country that has initiated the certification scheme. This dissertation argues that biofuels certification schemes, as currently drafted, are inconsistent with WTO trade agreements. Biofuel policies and certification schemes need to be better coordinated internationally to ensure that policy goals are met in a way that complies with trade agreements. The dissertation recommends that international standards need to be further developed to promote consistency between certification schemes and to support WTO consistency.
\end{abstract}

\title{
Word length
}

The text of this paper (excluding abstract, table of contents, footnotes, appendix and bibliography) comprises approximately 35,000 words. 


\section{INTRODUCTION}

Recent concerns about the impact of fossil fuels on climate change and the security of energy supply have resulted in biofuels being promoted as an alternative to oil. The use of biofuels as a renewable energy source is a promising tool for combating climate change, as it could result in a significant reduction of greenhouse gas emissions. This is reflected in the increasing number of national and regional governments that are introducing policies aiming to increase the proportion of biofuel use in their energy sector. Biofuel production in Europe, Brazil and the United States in particular is encouraged by policy measures such as tax exemptions, subsidies and obligatory levels of blending of biofuels with mineral fuels. ${ }^{1}$ Research and development is supported by several national governments, including research into new technologies for biofuel production and support for pilot or demonstration plants.

Although the increase in production of biofuels offers new opportunities, it also carries risks. Over the last five years, scepticism about the positive impact of biofuels has escalated, along with concerns about the environmental impact of increased biofuel production. Critics have voiced concerns about the true ability of biofuels to mitigate climate change. Although some experts estimate that the best biofuels can offer greenhouse gas savings $^{2}$ of up to 80 per cent, others have estimated that certain types of biofuels offer no greenhouse gas savings at all. ${ }^{3}$ Furthermore, biofuel production can have damaging effects to the environment, particularly if natural forested land of high biodiversity value is cleared for crop production. Some methods of cultivation can also cause environmental problems such as soil degradation or water pollution. ${ }^{4}$ As the feedstock used to produce biofuels (such as corn, sugar, cereals and oilseeds) are also food crops, the expansion of biofuels could result in a rise in food prices globally.

There is increasing pressure on governments to maximise the benefits of biofuel use, while minimising the possible negative impacts of their production. In response to this pressure, some governments are initiating measures to ensure that biofuel production will result in the anticipated reduction in greenhouse gas emissions, without causing

\footnotetext{
${ }^{1}$ Martin Banse, Hans van Meijl, Andrezej Tabeau and Geert Woltjer, "Will EU biofuel policies affect global agricultural markets?” (2008) 35(2) European Review of Agricultural Economics 118.

${ }^{2}$ Greenhouse gas savings is defined as the level of reduction of greenhouse gas emissions achieved through the production and use of biofuel in place of fossil fuel, calculated on a life-cycle basis. This is further described in Chapter II.

${ }^{3}$ Government of the United Kingdom, “The Government's response to the house of commons Environmental Audit Committee's report 'Are biofuels sustainable?’” (2008) 1 J. P. L. 1268.

${ }^{4}$ Noushin Ketabi, "The blood of going green: using environmental initiatives to account for the human rights violations of the green movement” (2009) 32 Fordham Int'l L.J. 1917.
} 
environmental damage in ecologically sensitive areas. Such policy initiatives include the development of certification schemes for the sustainable production of biofuels, and support measures to encourage the development and production of biofuels that are more likely to confer environmental benefits.

This dissertation argues that biofuels certification schemes, as currently drafted, are inconsistent with WTO trade agreements. Biofuel policies and certification schemes need to be better coordinated internationally to ensure that policy goals are met in a way that complies with trade agreements. The dissertation recommends that international standards need to be further developed to promote consistency between certification schemes and to support WTO consistency.

Chapter II of the dissertation describes biofuel production and trade and expands on the environmental and other risks associated with expanded biofuel production. Chapter III describes the types of policies that are developed by governments in attempts to ensure that biofuel production has minimal environmental and social impacts, including commentary on where inconsistencies exist. Some certification schemes are well developed and are being implemented or are close to implementation. These certification schemes are described, with a focus on those developed by governments, as these are most likely to affect trade and be subject to WTO trade agreements.

Chapter IV outlines the concerns regarding the consistency of biofuel certification schemes with WTO Agreement on Technical Barriers to Trade (TBT Agreement) ${ }^{5}$. This chapter finds two areas in which certification could be seen as inconsistent, and highlights that biofuel certification schemes need further international coordination and consistency. There is currently no international agreement specifically addressing biofuel production and trade. Chapter IV concludes that, if one were to exist, it would support an argument that biofuel certification measures are consistent with WTO rules, provided that there is a relationship between the measure and the policy goal, and it is applied in a way that is not arbitrary or discriminatory.

The examination of how greater international consistency could be achieved is the subject of Chapter V. It examines existing relevant international agreements that could be used as the basis for international standards promoting the sustainable production of biofuels.

\footnotetext{
${ }^{5}$ Agreement on Technical Barriers to Trade (15 April 1994).
} 
For some common criteria used in certification schemes, such as those relating to the protection of biodiversity, there are international agreements and standards that could be referenced or used as a basis for the measures. For other certification criteria, no such standard currently exists, and international dialogue needs to be initiated to develop a consistent approach. For example, as an initial step an internationally agreed methodology, developed under existing agreements, for measuring greenhouse gas savings associated with different types of biofuels could ensure that both certification schemes and other policy measures are effective in encouraging production of the most environmentally beneficial biofuels. A longer-term step would be the development of a new international standard covering other biofuels certification criteria. Chapter VI presents the conclusions of the dissertation. 


\section{BACKGROUND}

Biofuels are fuels that are produced, through a process of distillation, from plant products such as grains, sugar or oil seeds, rather than fossil fuels. Most types of agricultural or forestry plant matter (referred to as “feedstock") can be used to produce biofuel, given the appropriate technology. There are two main types of biofuels that are produced - bioethanol and biodiesel - and these are referred to as “first generation” biofuels. These are both liquid fuels and can be directly substituted for petroleum-based fossil fuels; together they account for almost all of global biofuel usage. ${ }^{6}$ Current research is focusing on techniques to produce what are called "second generation" biofuels. These are fuels that are produced from cellulosic biomass material such as wood, straw, grass, organic wastes and algae.

This chapter describes the potential of the different types of biofuels to replace conventional fuels and to reduce greenhouse gas emissions. It also explores the potential adverse affects of increased biofuel production and trade, which have promoted the development of certification schemes and other policy initiatives. The effectiveness of these policies is discussed in Chapter III.

\section{A Biofuel production}

Bioethanol is the most commonly produced type of biofuel, accounting for about 84 per cent of global production in 2009. ${ }^{7}$ Ethanol is produced from feedstock that contains a high level of sugar, such as sugarcane, corn, sugar beet and starchy cereal crops. The sugar from these crops is fermented and distilled into ethanol using either biologic or chemical processes. Producing ethanol from sugarcane is the most efficient method; the use of other feedstock such as corn is less efficient, but in most cases the amount of energy produced is greater than the amount of energy required for the production process. ${ }^{8}$ The production of ethanol from corn in particular has been criticised as relatively inefficient because it uses only a small portion of the plant, leaving a high level of waste. ${ }^{9}$

\footnotetext{
${ }^{6}$ Annie Dufey, Biofuels Production, Trade and Sustainable Development: Emerging Issues. International Institute for Environment and Development, Sustainable Markets Discussion Paper Number 2. London, $2006,3$. ${ }^{7}$ OECD-FAO Agricultural Outlook 2011-2020 - Database. http://www.agrioutlook.org/document/15/0,3746,en_36774715_36775671_48172367_1_1_1_1,00.html. Data extracted 26 November 2011.

${ }^{8}$ Natalie Jean Kurz, "Corn ethanol: setting straight a misguided attempt to free the United States from foreign oil” (2009) 31 Hous. J. Int'l L. 381.

9 Evan Turgeon, "Federal forests, biomass, and ethanol: energy security sabotaged" (2009) 39 Envtl. L. Rep. News \& Analysis 10143-4.
} 
Ethanol has advantages as a substitute for petroleum in transport fuel. Compared with gasoline, ethanol is a clean fuel, emitting less carbon monoxide, sulphur dioxide and paniculate matter. ${ }^{10}$ Ethanol can be used as a transport fuel in pure form, but only in specially adapted vehicles. It can alternatively be blended with gasoline with up to 10 per cent content without the need for engine modification. ${ }^{11}$ The main disadvantage of ethanol is that it tends to absorb water and impurities which can make it unusable as fuel. For this reason, it can’t be transported in existing pipelines; either dedicated pipelines are needed, or it must be transported by truck or rail, lowering its energy efficiency. ${ }^{12}$

Biodiesel is the other main type of biofuel produced, with a global production about 17 billion litres in 2009 - a small amount compared to global bioethanol production. ${ }^{13}$ Biodiesel is produced from oilseed crops, including sunflower seed, rape seeds, soy, palm and jatropha. Production involves extracting the oil from the feedstock. The oils are then converted into fatty-acid methyl ester (biodiesel) using a chemical transesterification process.

Biodiesel can be used as a transport fuel either in pure form, or blended with conventional diesel; the most common blend is 5 per cent biodiesel. ${ }^{14}$ Biodiesel doesn't have the limitations of ethanol in absorbing water and impurities.

Current research is focusing on techniques to produce second generation biofuels from cellulosic biomass material such as wood, straw, grass, organic wastes and algae. Cellulosic material is more difficult to break down than starch, sugar and oils. The process uses an enzyme or acid treatment to break down plant cellulose into sugar, which would then be fermented to produce ethanol. Another method of creating biofuel is biomass gasification. This method would break down the cellulose using a thermo-chemical process, to produce a gas which is then converted into ethanol or biodiesel using a catalyst. ${ }^{15}$

\footnotetext{
${ }^{10}$ Frank Seminerio, “A tale of two subsidies: How federal support programs for ethanol and biodiesel can be created in order to circumvent fair trade challenges under World Trade Organization rulings” (2008) 26 Penn St. Int'l L. Rev. 982.

${ }^{11}$ Dufey, above n 6, 3.

${ }^{12}$ Kurz, above n 8, 382.

13 OECD-FAO, above $\mathrm{n} 7$.

${ }^{14}$ Dufey, above n 6, 3.

${ }^{15}$ A full explanation of the processes used to produce second generation biofuels is provided by Euractiv online article "Biofuels: The Next Generation" 13 July 2009 http://www.euractiv.com/en/energy/biofuelsgeneration/article-165951). For detailed analysis of the status of second generation technologies, see International Energy Agency (IEA) "From $1^{\text {st }}$ to $2^{\text {nd }}$ Generation Biofuel Technologies: An Overview of Current Industry and R\&D Activities” OECD/IEA, Paris, 2008.
} 
Biofuel produced from algae is sometimes referred to as "third generation" biofuel. Under appropriate growing conditions, some strains of algae can store large amounts of oil within cells. This oil can be extracted in a similar manner to oil from vegetable matter (such as oil seeds), and used to produce biodiesel. Although the potential of biofuel production from algae is well recognised, the production costs are considered to be prohibitive. ${ }^{16}$

Second generation biofuels would bring significant advantages over those currently produced. Firstly, there is potential to use a much wider range of feedstock including forestry and waste products. Such feedstocks are generally preferable in terms of environmental sustainability, and they could be grown on land that is marginal, degraded or otherwise unproductive for growing food crops. This would avoid claims that biofuel production is competing for land mass with food production (a debate explored later in this chapter). Recent research has modelled the effects of both conventional and second generation biofuels, and has found that the production of second generation biofuels would have a lesser impact on staple food prices, and has highlighted the importance of the investment in research and technology that is needed by national governments to address the environmental impacts arising from intensive agriculture. ${ }^{17} \mathrm{~A}$ second advantage is that second generation methods would use the entire above-ground portion of a plant, rather than just the plant parts that are high in sugar or oil, resulting in a higher yield of fuel per unit area of land. As a result, second generation methods would yield more biofuel per ton of biomass than current methods, potentially resulting in fewer greenhouse gas emissions. ${ }^{18}$

The challenges of second generation biofuels are two-fold; firstly, developing the technology to produce them cost-effectively; and secondly, the challenge of using residue material on a large and commercial scale. It should also be noted that the environmental benefits of second generation biofuels is largely dependent on the land used for feedstock production; if this diverts land from crop production or involves clearing of forest, the benefits will not be as evident. A study by the International Panel for Sustainable Resource Management (IPSRM) recommends that investments into research and development should be accompanied by monitoring of land use and associated environmental impacts. ${ }^{19}$

\footnotetext{
${ }^{16}$ OECD/IEA, above n 15, 83.

17 Siwa Msangi and Mark Rosegrant “Agriculture and the environment: Linkages, trade-offs and opportunities” (2007) 19 Geo. Int'l Envtl L. Rev. 709.

${ }^{18}$ Turgeon above n 9, 10140.

19 International Panel for Sustainable Resource Management, Towards Sustainable Production and Use of Resources: Accessing Biofuels. United Nations Environment Programme, Paris, 2009, 92.
} 


\section{B Biofuel trade}

The production of biofuels is growing rapidly worldwide. Ethanol production globally tripled between 2000 and 2007 and biodiesel production increased more than four-fold over the same period. ${ }^{20}$ The global demand for biofuels is expected to continue to grow strongly. A recent OECD-FAO report predicts that bioethanol production will increase by 47 per cent between 2011 and 2020, and biodiesel production will increase by 79 per cent over the same period. ${ }^{21}$ The global demand for energy may double by 2050 (compared with demand in 2000), and some experts estimate that biofuels could supply up to 50 per cent of this demand depending on land availability and technology development. ${ }^{22}$ Other experts state that this market share is unlikely to be realised due to sustainability concerns; a more realistic estimate is a 13 per cent market share in $2050 .{ }^{23}$ Brazil was the first country to initiate large-scale production of biofuel, and from the early 1970s to the mid 1990s it remained the only country with significant commercial production. However, at the current time many countries are engaged in biofuel production, or have plans to become so.

Bioethanol production is concentrated in the United States (about 48 per cent in 2009, mostly from corn) and Brazil (about 27 per cent in 2009, mostly from sugarcane). China, the European Union, India and Canada also produce bioethanol, to a smaller extent. ${ }^{24}$ Brazil is the most efficient bioethanol-producing country due to the ideal sugarcane growing conditions and low production costs, and it is also considered the most successful. The biofuel produced is mainly for the domestic market, where it used as fuel for over 70 per cent of vehicles as either a ethanol-gasoline blend or as pure hydrated ethanol. Brazil's exports of biofuels are also increasing, and it has commenced a biodiesel program. ${ }^{25}$ In the United States, bioethanol from corn has been produced since the 1970s, but only recently at commercial levels. ${ }^{26}$ Ethanol production in the United States is encouraged by quotas set in

\footnotetext{
${ }^{20}$ Banse, above n 8, 117. References Licht Interactive Data 2007.

${ }^{21}$ OECD-FAO, above n 7.

${ }^{22}$ M. Hoogwijk, A. Faaij, R. van den Broek, G. Berndes, D. Gielen, and W. Turkenburg, "Exploration of the ranges of the global potential of biomass for energy” (2003) 25 Biomass and Bioenergy 119; J. Goldemberg and T. Johansson, World Energy Assessment- Overview 2004 Update. United Nations Development Programme, New York, 2004.

${ }^{23}$ Richard Doornbosch and Ronald Steenblick, Biofuels: Is the Cure Worse than the Disease? Organisation for Economic Co-operation and Development SG/SD/RT(2007)3/REV1, Paris, 2007, 5-6. References data from the International Energy Agency.

${ }^{24}$ OECD-FEO, above $n 7$.

${ }^{25}$ Dufey, above n 6, 5; Robert Howse, Petrus van Bork and Charlotte Hebebrand, WTO Disciplines and Biofuels: Opportunities and Constraints in the Creation of a Global Marketplace. IPC Discussion Paper, International Food and Trade Policy Council, Washington USA, 2006, 7.

${ }^{26}$ Dufey, above n 6, 5-6.
} 
the Energy Policy Act 2005, as well as subsidies to the corn industry (discussed further in chapter III).

Biodiesel is produced mostly in the European Union from oilseeds, including rape seed, sunflower seed and soybean. The European Union produced about 55 per cent of biodiesel globally in 2009, with production dominated by Germany, France and Italy. The United States produced almost 10 per cent of global biodiesel in 2009. ${ }^{27}$ Biodiesel production is part of the European promotion of renewable energy as an alternative to fossil fuels. In several countries including Germany, biodiesel production is stimulated by tax exemptions. There are also large-scale projects underway in France and Germany to develop second generation biodiesel technology. ${ }^{28}$

Although at present Brazil, the United States and the European Union are the leaders in biofuel production, many developing countries in South America, Africa and Asia are initiating biodiesel programmes. For example, Malaysia, Thailand, Indonesia, the Philippines and India are all establishing significant plantations of biodiesel feedstock such as palm oil. ${ }^{29}$ Tropical and sub-tropical climates are the most ideal for growing feedstock such as sugarcane and oil palm trees, which would give many developing countries a competitive edge in biofuel production. If successful industries are established in tropical regions, this would create a disparity between the locations of biofuel production (tropical areas), and the location of highest demand for their use (OECD countries which are predominantly located in temperate areas). To date, this disparity has not been important; however as production and demand increase, this could result in an increased level of trade in biofuels.

Although biofuels have traditionally been produced for domestic use, the trade in feedstock for biofuel production has been increasing, and over eight per cent of global production was traded internationally in $2008 .^{30}$ The level of trade is expected to increase as biofuel use becomes more common. Trading patterns are likely to be complicated, particularly due to the links with other markets, such the food, fodder and energy markets. ${ }^{31}$

\footnotetext{
${ }^{27}$ OECD-FAO, above n 7.

${ }^{28}$ Dufey, above n 6, 9.

${ }^{29}$ Howse, above $n$ 24, 5.

${ }^{30}$ OECD-FAO, above $n 7$.

${ }^{31}$ M. Verdonk, C. Dieperink and A.P.C. Faaij “Governance of the emerging bio-energy markets” (2007) 35 Energy Policy, 3910.
} 
Brazil is the largest exporter of biofuel, with an estimated share of about 60 per cent in 2005. ${ }^{32}$ In 2008 Brazil exported 5.16 billion litres of bioethanol; the major markets supplied are India and the United States. ${ }^{33}$ The United States, France, the United Kingdom and South Africa also all export bioethanol, to a much smaller degree. ${ }^{34}$

The largest bioethanol importing country is the United States, which accounts for about 31 per cent of global imports with over half originating from Brazil. Other significant importing countries are Mexico, Korea and Germany. ${ }^{35}$ Trade in biodiesel is less well developed, but increasing. For example, the European Union imports about 3.5 million tonnes of palm oil per year from Malaysia and Indonesia, and this is predicted to rise due to new palm oil refineries being established; eventually imported palm oil is expected to supply up to 20 per cent of the biodiesel market in the European Union. The United States also imports some palm oil biodiesel from Ecuador. ${ }^{36}$

Trade in biofuels is encouraged by the need to meet biofuel blending targets put into place by national governments, especially where domestic production is unlikely to meet the demand. In particular, the mandatory targets of biofuel use in the European Union are driving the production and trade of biofuel stock in developing countries. ${ }^{37}$ However, trade in biofuels is also constrained by import tariffs and production subsidies that protect domestic industries and artificially inflate prices. ${ }^{38}$ As the volume of trade grows, the biofuel policies of importing countries will come under increasing scrutiny, both for their potential environmental and social consequences, and for their consistency with WTO trade agreements. The potential problems arising from this are the subject of Chapter IV.

\footnotetext{
${ }^{32}$ Edward Smeets, Martin Junginger, Andre Faaij, Arnaldo Walter, Paulo Dolzan and Wim Turkenburg, “The sustainability of Brazilian ethanol - An assessment of the possibilities of certified production” (2008) 23 Biomass and Bioenergy 782.

${ }^{33}$ Stefan Bringezu, Helmut Schutz, Meghan O’Brien, Lea Kauppi, Robert Howart, Jeff McNealy Towards sustainable production and use of resources: assessing biofuels. United Nations Environment Programme, 2009; Jinke van Dam, Martin Junginger, Andre' Faaij, Ingmar Jurgens, Gustavo Best, Uwe Fritsche, “Overview of recent developments in sustainable biomass certification” (2008) 32 Biomass and Bioenergy, 750.

${ }^{34}$ Martin Junginger, Torjus Borkesjo, Douglas Bradley, Paulo Dolzan, Andre Faaij, Jussi Heinimo, Bo Hektor, Oyvind Leistad, Erik Ling, Miles Perry, Erik Piacente, Frank Rosillo-Calle, Yves Ryckmans, Peter-Paul Schouwenberg, Birger Solberg, Erik Tromborg, Arnaldo da Silva Walter and Marc de Wit, "Developments in international bioenergy trade” (2008) 32 Biomass and Bioenergy 726.

${ }^{35}$ Dufey, above n 6, 13.

36 Ibid., 14.

${ }^{37}$ Banse, above n 1, 299; Howse, above n 24, 4-5

${ }^{38}$ Doornbosch, above n 23, 8.
} 


\section{Sustainability issues}

A global market for biofuels appears to be emerging, and is strongly linked to both the energy and agricultural markets. If biofuels are to make a significant contribution to energy supply and climate change mitigation, further globalisation in production and trade will be needed. ${ }^{39}$ Yet the consequences of the increased production and trade are unknown with respect to environmental sustainability ${ }^{40}$, competition with food crops, and other environmental, social and economic impacts. It is essential that the emerging biofuels sector develops on a "level trade policy playing field" to ensure its long term efficiency and environmental sustainability, and to ensure that developing countries are able to access the benefits of the market. ${ }^{41}$

International trade in biofuels and related feedstock may provide both benefits and negative impacts. On the positive side, trade in biofuels could provide a win-win situation for both importing and exporting countries. For exporting countries, it is an opportunity to initiate or grow a profitable industry; for importing countries, biofuels will help to meet renewable energy targets, increase energy security, and reduce greenhouse gas emissions. However there are potential negative aspects associated with biofuel production. These include biodiversity loss, other environmental degradation, an influence on global food prices, and negative social impacts.

\section{Greenhouse gas reduction}

The use of energy from renewable sources such as biofuels is consistent with measures needed to reduce greenhouse gas emissions and comply with the Kyoto Protocol to the United Nations Framework Convention on Climate Change. Many developed nations have made commitments towards mitigating climate change. For example, the European Union has made a commitment to reduce greenhouse gas emissions by 8 per cent from 1990 levels by $2012{ }^{42}$ It is acknowledged that the use of fossil fuels for energy is one of the

\footnotetext{
${ }^{39}$ Arthur Mol "Environmental authorities and biofuel controversies” (2010) 19(1) Envt’l Pol., 62.

${ }^{40}$ In this paper, the term 'sustainability' is defined according to the Brundtland Commission of the United Nations (March 20, 1987) "sustainable development is development that meets the needs of the present without compromising the ability of future generations to meet their own needs". Sustainability encompasses environmental, social and economic spheres.

${ }^{41}$ Doaa Abdel Motaal, “The Biofuels Landscape: Is There a Role for the WTO?” (2008) 42(1) Journal of World Trade, 61.

${ }^{42}$ Karolien Verhaegen, Leonardo Meeus and Ronnie Belmans, "Towards an international tradable green certificate system - The challenging example of Belgium” (2009) 13 Renewable and Sustainable Energy Reviews 209.
} 
factors contributing to climate change; as such attention has turned to alternative energy sources.

Biofuels are a form of energy that could play a useful role in mitigating climate change. ${ }^{43}$ The growing of feedstocks absorbs $\mathrm{CO}_{2}$ from the atmosphere; when the biofuel is used, the $\mathrm{CO}_{2}$ is released but does not count as new carbon emissions since it part of the fixed carbon cycle. ${ }^{44}$ The International Energy Agency has estimated that, if biofuels (from sugarcane and second generation methods) can meet 13 per cent of transport fuel demand in 2050, this will result in a 3 per cent reduction in $\mathrm{CO}_{2}$ emissions. ${ }^{45}$

Estimating the greenhouse gas savings from biofuel production is complex, as the calculation needs to account for the entire fuel cycle, from production of the feedstock to the time the fuel is used. This is called life cycle analysis, and compares the emissions of greenhouse gas throughout the fuel cycle with the emissions that would have resulted from using fossil fuels. The life cycle analysis can also account for changes in land use due to production, for example the clearing of native forest. ${ }^{46}$

Estimates of greenhouse gas savings from biofuels vary depending on the type of feedstock, method of cultivation, conversion technology, and methodology used for the life cycle analysis. Estimates can be negative, showing that certain biofuels may emit more greenhouse gas than if an alternative fossil fuel were used. ${ }^{47}$ For ethanol produced from corn, the estimates range from 59 to 93 per cent reduction in greenhouse gas emissions, and for biodiesel the estimates range from 41 to 95 per cent reduction in greenhouse gas emissions. Production of ethanol from cellulosic material has an even wider range of estimates, from a 113 per cent reduction to a 93 per cent increase in greenhouse gas emissions (reflecting the developing state of this production method). ${ }^{48}$ According to the Brazilian President, the use of ethanol in place of petroleum has reduced emissions of carbon dioxide in Brazil by 800 million tons. ${ }^{49}$ A modelling study has shown that the liberalization of trade in biofuels should

\footnotetext{
${ }^{43}$ Verdonk, above n 31, 3909.

${ }^{44}$ Dufey, above n 6, 41.

${ }^{45}$ Doornbosch, above n 23, 23. References data from the International Energy Agency.

46 Bruce McCarl and Fred Boadu, "Bioenergy and U.S. renewable fuels standards: law, economic, policy/climate change and implementation concerns.” (2009) 14 Drake J. Agric. L., 54.

${ }^{47}$ Dufey, above n 6, 40.

${ }^{48}$ All statistics in above paragraph from Perrihan Al-Riffai, Betina Dimaranan and David Laborde Global Trade and Environmental Impact Study of the EU Biofuels Mandate. International Food Policy Research Institute, Washington, 2010, 12.

49 Yuri de Lima Mantilla, "The survival of the United States ethanol subsidies and tariff: Are there further reasons to keep them on the books?” (2008) 15 ILSA J. Int'l \& Comp. L., 207. References online article “Lula
} 
be beneficial in reducing greenhouse gas emissions. Although increased trade is likely to result in more land being cleared, there will also be a shift towards producing the most emission-efficient biofuels, such as sugar cane ethanol. ${ }^{50}$ Biofuels also have the potential to reduce emissions of other toxic substances usually associated with standard fuels. For example, engines running on biofuels or on blended fuels tend to have lower particulate and CO emissions and lower sulphate emissions. ${ }^{51}$

The wide range of estimates, different methods of calculation, and different feedstocks make it difficult to predict the impact that biofuels are likely to have on reducing greenhouse gas emissions. Countries that are setting greenhouse gas reduction targets, through the use of biofuels, are now moving towards identifying which biofuels are the most efficient to produce, and creating policy incentives for their production. This is not an easy task, as there is considerable uncertainty about the degree to which biofuel production and use would reduce greenhouse gas emissions, if at all. There are a number of factors which amount to "leakage" of energy which are not always taken into consideration when calculating potential greenhouse gas reductions; these factors raise doubts about the benefits of biofuels. ${ }^{52}$

For example, calculations do not always account for the long distance transportation of biofuels, either after production, or of transporting the feedstock to the refinery. This is particularly an issue for ethanol transport which, due to its nature, cannot be transported in existing pipelines. ${ }^{53}$ The energy used for transportation could significantly reduce the benefits of biofuel use, in terms of greenhouse gas emissions. Another factor often not taken into account is the energy that is embedded in fertiliser, which is used to grow the feedstock. Kurz (2009) states that when all elements of the industrial process are taken into account, including the use of fertilizers, more energy is required to produce corn-based ethanol than is gained from the end product itself. ${ }^{54}$

One of the most common criticisms is that the calculation of greenhouse gas emissions from biofuel production does not adequately take into account the changes in land

Proposes a "Global Pact" Over Biofuels and Says that Kyoto has Failed” 27 May 2008 http://ethanolbrasil.blogspot.com/2008/06/lula-culpa-lobbyde-petrleo-por.html. English translation not available.

${ }^{50}$ Al Riffai, above n 48, 12.

${ }^{51}$ Dufey, above n 6, 43.

52 There can also be positive leakage, for example increased grain prices resulting in a decline in livestock, which account for significant greenhouse gas emissions. See McCarl, above n 46, 58.

53 Smeets, above n 32, 793.

${ }^{54}$ Kurz, above n 8, 411. 
use that biofuel production often requires. The impact of land use changes is complex. Direct land use changes occur when native vegetation is cleared for biofuel production, which may result in a large release of carbon into the atmosphere. The Brazilian government, for example, has been criticised for expanding sugar-cane production into Amazon areas. ${ }^{55}$ There are also indirect land use changes - if existing farmland is used for biofuel feedstock production, further land clearing for food crop production may be needed. Land use changes create "carbon debts" which need to be repaid through the use of biofuel, and could take decades or even centuries to repay. Another land use issue is the greenhouse gas emissions from below-ground biomass, leaf litter, dead wood and soil organic matter. When all land use changes are taken into account, some models suggest that greenhouse gas emissions may increase as a result of the land clearing needed to meet the demand for biofuels. ${ }^{56}$ One way to mitigate this risk would be to use idle land or waste land for biofuel production where possible - some energy crops can be grown on degraded land and even used to restore the land. For example, jatropha can store moisture, stabilise soil and slow down desertification. ${ }^{57}$

\section{Biodiversity loss}

In addition to the concerns about greenhouse gas emissions, the clearing of land from forest and agricultural systems for the purpose of biofuel production can also result in negative ecological and social impacts. For example, clearing land, particularly tropical rainforest land, can reduce biodiversity and impact on soil and water quality.

Biofuel feedstocks are most efficiently produced in tropical regions (which are typically areas of high biodiversity) providing incentive for the replacement of natural tropical ecosystems - including forests, wetlands and grasslands - with biofuel crops. ${ }^{58}$ There can also be indirect biodiversity loss, if displaced food crop land moves into native forest. Land clearing results in loss of habitat for endangered species, and as a consequence, a reduction in biodiversity. This has follow on effects of soil and water degradation, obstruction of migration patterns and loss of opportunities for exploiting species that become extinct. $^{59}$

\footnotetext{
55 de Lima Mantilla, above n 49, 208-10.

${ }^{56}$ Emma Frow, David Ingram, Wayne Powell, Deryck Steer, Johannes Vogel and Steven Yearly, "The politics of plants.” (2009) 1 Food Sec., 20.

${ }^{57}$ Dufey, above n 6, 44.

58 Doornbosch, above n 23, 4.

${ }^{59}$ McCarl, above n 46, 64.
} 
The Convention on Biological Diversity states that efforts should be made to protect ecosystems and habitats containing high diversity, large numbers of endemic or threatened species, and wildernesses needed by migratory species. ${ }^{60}$ Even so, there is already evidence of biodiversity loss in some areas due to biofuel production. For example, rainforest and savannah in Brazil - both biodiversity rich areas - have been cleared due to the expansion of sugarcane. Similarly, conservation areas in the United States are threatened by ethanol production. ${ }^{61}$ The increased use of oilseed in Germany and France has displaced habitat for a variety of bird species. ${ }^{62}$

\section{Environmental degradation}

Although there are significant potential environmental advantages associated with biofuel production, there are also concerns that production could have negative environmental impacts. These are generally associated with intensive feedstock cultivation, and include:

- Soil degradation. The replacement of native biomass with cropping systems can have negative consequences on the soil, including nutrient loss, higher soil temperatures, decreased carbon sequestration rates and lower microbial activity. ${ }^{63}$ Soil erosion is common in agricultural systems, including sugar cane production, and prevention technologies such as contour ploughing and bench terracing are recommended in these situations. ${ }^{64}$

- Water degradation. Many biofuel feedstocks are water intensive crops; their production can reduce natural water flow, and decrease water quality due to the use of agrochemicals. An increase in irrigated land in arid or semi-arid areas could lead to water scarcity, a lowering of water tables and increased salinity. ${ }^{65}$

- Chemical and pesticide toxicity. Feedstocks such as corn require pesticides and nitrogen fertiliser. Chemical runoffs can promote excessive plant growth and decay in watersheds and reduce water quality. ${ }^{66}$

\footnotetext{
${ }^{60}$ Convention on Biological Diversity (5 June 1992) 1760 UNTS 79.

${ }^{61}$ Kurz, above n 8, 411.

${ }^{62}$ Erik Bluemel, "Biomass energy: ensuring sustainability through conditioned economic incentives" (2007) 19 Geo. Int'l Envtl. L. Rev. 683.

63 Turgeon, above n 9, 10148.

${ }^{64}$ Smeets, above n 32, 788.

65 Uwe Fritsche, Katja Hunecke, Andreas Hermann, Falk Schulze and Kirsten Wiegmann, Sustainability Standards for Bioenergy. WWF, Frankfurt, 2006, 19.

66 Turgeon, above n 9, 10149.
} 
- Increased risk of invasion, both from the feedstock plants themselves and from the spread of pests and diseases associated with them. ${ }^{67}$

- Spread of genetically modified feedstocks. ${ }^{68}$

It should be noted that the negative environmental effects of biofuel production should be assessed in comparison to alternative land uses. The environmental issues listed above are common to many agricultural systems, and the environmental problems associated with biofuels could be less than those associated with traditional agricultural practices. However, compared to a natural ecosystem, there are clearly adverse environmental effects associated with biofuel production.

\section{$4 \quad$ Food security risks}

The rapid growth in demand for biofuel could result in crop land - currently being used to produce food crops - being diverted to produce biofuel feedstocks. It is likely that land use constraints will limit the amount of new land that can be used for crop production. As food and biofuel are competing for the same inputs, this has led to a highly controversial “food versus fuel” debate. ${ }^{69}$

A large scale change of food-producing land to biofuel-producing land would have significant impacts on the wider global economy. In addition to the competition between food and fuel for land and inputs, the production of fuel from plant products becomes more competitive as the price of oil rises, increasing the demand for plant products. This results in a scarcity on the food market, which can cause the price of the agricultural commodities to rise. If oil prices are high, food and energy markets will be more interlinked, and economists predict that oil prices would provide both a floor and ceiling effect on prices of food commodities. $^{70}$ It is predicted that the long term trend of declining prices for agricultural commodities will slow down or reverse for the feedstock used for biofuel, if there is an enhanced demand for biofuel crops. ${ }^{71}$

\footnotetext{
${ }^{67}$ Geoffery Howard "Risks of invasion from biofuel feedstocks: terrestrial, freshwater and marine” Workshop on biofuel production and invasive species, Nairobi, 20-22 March 2009.

${ }^{68}$ Smeets, above n 32, 790.

${ }^{69}$ Doornbosch, above n 23, 4.

${ }^{70}$ Josef Schmidhubner, Biofuels: an emerging threat to Europe's food security? Impact of an increased biomass use on agricultural markets, prices and food security: a longer-term perspective. Notre Europe, Paris, 2007.

${ }^{71}$ Banse, above n 1, 135.
} 
High prices are particularly a problem as food becomes inaccessible for poor consumers. A study by the International Food Policy Research Institute has predicted that, for every percentage increase in the price of staple foods, due to the demand for biofuels, the number of people lacking food security will rise by 16 million. ${ }^{72}$ For developing countries, food insecurity could offset the positive impacts of biofuel production, such as increased employment.

There are some examples where policies to encourage biofuel production have had a direct negative effect on food availability in vulnerable areas. For example, the United States has promoted bioethanol production through target-oriented incentives, resulting in record amounts of corn being planted in the United States, of which more than one quarter has been used to make bioethanol. ${ }^{73}$ This has been named as one of the key factors in the rise in price of tortillas in Mexico in 2007. ${ }^{74}$ Recent studies estimate that, if oil prices remain high, increased biofuel production would cause the global corn prices to rise by up to 41 per cent by $2020 .^{75}$ The increase in sugar cane production in Brazil has caused a reduction in production of other crops such as tomato, peanuts, oranges and coffee and has caused land prices to double in some regions. It is expected that this will lead to an impact on food prices. $^{76}$

The rise in production of biofuel has been cited as one of the possible causes of the dramatic food price rises during 2007 and 2008. During this time, nearly all agricultural commodities were affected, and some food prices rose by nearly 40 per cent. ${ }^{77}$ The role of biofuels in the food price increase is much debated; several studies have sought to quantify the impact, and there are a wide variety of conclusions. The most commonly cited study is by Rosegrant (2008) who estimated that the biofuel demand accounted for 30 per cent of the increase in grain prices, and 39 per cent of the increase in corn prices. However, there is broad agreement that there were a number of contributing factors, in addition to biofuels, including weather conditions and oil prices. ${ }^{78}$

\footnotetext{
${ }^{72}$ Ketabi, above n 4, 414-415.

${ }^{73}$ McCarl, above n 46, 49.

${ }^{74}$ Frow, above n 56, 19.

${ }^{75}$ Ketabi, above n 4, 414.

${ }^{76}$ Smeets, above n 32, 794.

77 Mark Rosegrant, Biofuels and Grain Prices: Impacts and Policy Responses International Food Policy Research Institute, Washington, 2008, 1.

${ }^{78}$ Ibid., 1-2. For further discussion, see Perrihan Al Riffai, above n 48, 17.
} 
Conversely, there are others who argue that the production of biofuels does not have an impact on food security, and that no causality has been established between biofuel production and the 2007/08 food price rises. The supporting arguments are that there is sufficient land available for biofuel production, without impacting on food production, that biofuel production will not displace oil use, and that lack of food security is more a result of distribution and access to food, rather than a production problem. ${ }^{79}$

\section{$5 \quad$ Rural communities}

The production of biofuels can provide opportunities for employment and stimulate development particularly in rural areas in countries that are net agricultural producers. In these regions, increased agricultural production can revitalise rural economies and help reduce poverty in rural areas.

Even in some developed counties, rural areas have suffered from low prices of agricultural products and overproduction. As such some governments, including the United States and European Union, heavily subsidise farmers and businesses for their involvement in biofuel production as a way to revitalise the economy in rural areas. ${ }^{80}$ There has also been significant private investment in biofuels and related technology. For example in the United States oil companies have set up research partnerships with universities, and their capital investment in biofuels was over US\$740 million in $2006 .{ }^{81}$

In developing countries, biofuel production can create opportunities for workers in rural areas. For example, bioethanol production in Brazil employed about one million workers in 2006, with the number expected to grow. In Colombia, a farming family producing bioethanol feedstock is estimated to earn 2-3 times the minimum salary. ${ }^{82}$ Biofuels would not only provide opportunities for developing countries to produce a product for the industrialised world, but would also help them to use biomass for their own energy needs, reducing expenditure on imported fossil fuels. Developing countries would also benefit from industry established to convert feedstock into fuel and the subsequent export of the biofuel. ${ }^{83}$

\footnotetext{
${ }^{79}$ For example, see McCarl, above n 46, 68-69; Dufey, above n 6, 48-49.

${ }^{80}$ Arthur Mol, "Boundless Biofuels? Between Environmental Sustainability and Vulnerability" (2007) 47(4) UK Sociologia Ruralis, 300.

${ }^{81}$ Frow, above n 56, 20.

${ }^{82}$ Dufey, above n 6, 46.

${ }^{83}$ However, the current tariff system may discourage the export of final product, rather than feedstock. For discussion see Dufey, above n 6, 46.
} 
Tropical regions in particular have an advantage in growing biofuel feedstocks, due to the favourable conditions, availability of land and low labour costs. ${ }^{84}$

There is a risk that foreign investors, rather than rural communities would gain the economic benefits. The cultivation of biofuel feedstock is usually associated with large scale production methods, which farmers in developing countries may have difficulty in implementing. They may additionally not have the expertise to diversify from traditional crops and farming practices. ${ }^{85}$ If biofuel production is initiated by foreign companies, there may be little improvement in local welfare, and additionally land tenure conflicts could arise if local communities are pushed from their land. There is evidence that land tenure conflicts arose in Brazil during the 1970s and 1980s due to the expansion of sugar cane production, with farmers being forced off their land. ${ }^{86}$ Large plantations of palm oil in Indonesia have also been linked to conflicts over land rights with local communities. ${ }^{87}$

The social and economic well-being of workers on biofuel feedstock plantations in developing countries is attracting increasing scrutiny, particularly in countries where labour standards are weak. For example, sugar cane cutting has been associated with cancer, caused by the soot produced during burning and the use of chemicals. There are also notable health and safety risks associated with the repetitive movements of cane cutting. ${ }^{88}$ In oil palm plantations, the use of fire to clear fields and the high use of agrochemicals expose local communities to air pollution. ${ }^{89}$ There are increasing concerns about poor labour practices, including the occurrence of child labour. For example it is estimated that over 5 per cent of the workers in Brazilian sugar cane plantations are between the ages of 10 and 17 years. ${ }^{90}$

\section{Conclusion}

It is clear that, while biofuels present many opportunities, their production also involves threats to the environment, economy and human health and wellbeing. With these potential benefits and concerns, it is becoming increasingly important to regulate biofuel production and trade to ensure that biofuels are produced sustainably and not causing unnecessary damage to the environment or community. The regulation of biofuels trade

\footnotetext{
${ }^{84} \mathrm{Mol}$, above n 39, 66.

${ }^{85}$ Charlotta Jull, Patricia Carmona Redondo, Victor Mosoti and Jessica Vapnek. Recent Trends in the Law and Policy of Bioenergy Production, Promotion and Use. FAO Legal Papers Online \#68, 2007, 18.

${ }^{86}$ Smeets, above n 32, 794.

${ }^{87}$ Dufey, above n 6, 48.

${ }^{88}$ Smeets, above n 32, 797.

89 Dufey, above n 6, 44; Ketabi, above n 4, 1936.

${ }^{90}$ Smeets, above n 32, 797
} 
should take care not to encourage biofuel production from inefficient feedstock, inefficient technology or on land that is in direct competition with food. ${ }^{91}$

There are various policy initiatives that can encourage the sustainable production of biofuels. One possible strategy is to set standards and establish certification schemes. Several such certification schemes have been initiated, and are at various stages of developing criteria to ensure environmental, social and economic sustainability. ${ }^{92}$ The policies being considered and implemented by governments and the main players in setting certification schemes for biofuel production are described in the following chapter.

\footnotetext{
${ }^{91}$ Motaal, above n 41, 86.

92 Simonetta Zarrilli and Jennifer Burnett, Making Certification Work for Sustainable Development: The Case of Biofuels. United Nations, New York and Geneva, 2008, 6, v.
} 
The use of biofuels as a renewable energy source is a promising tool for combating climate change, as it could result in a significant reduction of greenhouse gas emissions. Biofuels have the potential to be used to service the major energy sectors of heat, electricity and transport fuels, and therefore are a good way to diversify energy supply and reduce the traditional reliance on oil for energy. Biofuels have also been championed as a way to increase income for farmers and promote sustainable development in rural areas. ${ }^{93}$

The increased emphasis on protecting the environment, together with price rises of fossil fuels has stimulated many countries to promote the use of biofuels as alternative fuels. Biofuel production in the European Union and United States in particular is encouraged by policy measures, and since the 1970's, Brazil has supported successful large-scale programmes of biofuel production and use in the transport sector. ${ }^{94}$ Private parties such as fuel companies and non-government organisations (NGOs) are also becoming interested in the use of biofuels as an alternative energy source. As a result, production and trade volumes are growing rapidly, and the biofuel market may evolve into a global market with close links to other commodity markets. ${ }^{95}$

Government policies are put into place in many countries to make the production, trade and use of biofuels financially attractive. These policies come in a variety of types, including subsidies and support at various points of the supply chain, tax breaks, mandatory blending or quotas, and tariff or non-tariff trade barriers to protect domestic industries.

The importance of producing biofuels in a sustainable way is becoming increasingly obvious. For example, the European Union Environment Commissioner has admitted that it is preferable to miss the biofuel quota than to achieve it by harming the poor or damaging the environment. ${ }^{96}$ In most cases, government support of biofuels is not linked to sustainable production. However, in response to public pressure, some governments are initiating measures to ensure that biofuel production will result in the anticipated reduction in greenhouse gas emissions, without causing environmental damage in ecologically sensitive areas. Such policy initiatives include the development of certification schemes for the

\footnotetext{
${ }_{93}^{93}$ Jody M. Endres "Clearing the air: The meta-standard approach to ensuring biofuels environmental and social sustainability” (2010) 28 Va Envtl.L. J. 74.

94 Ibid., 74.

95 Verdonk, above n 31, 3909.

${ }^{96}$ Roger Harrabin "EU rethinks biofuels guidelines" BBC News 14 January 2008. This article quotes EU Environment Commissioner Stavros Dimas.
} 
sustainable production of biofuels, and support measures to encourage the development and production of biofuels that are more likely to confer environmental benefits. The most common initiative employed to date is the development of certification schemes, and the following chapters examine the concerns raised regarding the consistency of certification schemes with the WTO Agreements. This chapter describes some such certification schemes, and also other policy initiatives, in recognition that a comprehensive policy setting is likely to be needed to address the concerns regarding the sustainability of biofuels.

\section{A Government support for research and production of environmentally sustainable biofuels}

Subsidies and support can be applied at various points in the supply chain, with each having a certain impact on the market. Biofuel support mechanisms vary greatly between countries; examples include investments in infrastructure and transport of biofuels, research and development of new technologies, the promotion of vehicles able to be run on a highethanol fuel blend, tariffs on imported biofuel and feedstock, and tax incentives for domestically produced biofuel. Such support mechanisms can have implications for international trade, and for the geographical patterns of biofuel production. ${ }^{97}$

As biofuel is generally more expensive to produce than fossil fuel, the commercial viability of production may depend on government support. In addition to tax concessions and blending targets, production subsidies can also support the development and commercialisation of biofuels. The impact of biofuels on greenhouse gas emissions differs according to the feedstock used, agricultural practices and method of converting the feedstock to fuel. There is therefore potential to address the environmental concerns regarding biofuel production through support for the biofuels that have the most potential for greenhouse gas reduction and long term environmental sustainability. Support for second generation biofuels is the most promising way to achieve this, as these biofuels have the potential to yield more fuel per ton of biomass than first generation biofuels, which would potentially result in much greater greenhouse gas savings. ${ }^{98}$ It should also be noted that some first generation biofuels, such as ethanol from sugarcane, are as efficient to produce, and their value should not be overlooked. The following sections provide some examples of policies relating to support for biofuel through research and development for second generation

\footnotetext{
${ }^{97}$ Food and Agriculture Organization of the United Nations, The State of Food and Agriculture. FAO, Rome, 2008, 27.

98 Turgeon, above n 9, 10145
} 
biofuels, and support through favourable tariffs and subsidies. Policies relating to tax exemptions and blending mandates are described in a subsequent section on biofuels certification, due to the linkages between these policies and certification schemes.

\section{$1 \quad$ Current policies relating to production of second generation biofuels}

Some initiatives have been taken to support research and development of second generation biofuels. Such research is generally aimed at developing technology to improve the methods of converting feedstock into fuel. ${ }^{99}$

Although the feedstock needed to produce second generation biofuels is abundant and cheap, the cost of processing cellulosic material is currently higher than for biofuels produced from starch or oil seed crops due to the conversion technology needed to break down the material. A 2004 study by the International Energy Agency found that further research could reduce production costs to levels below those for grain-based ethanol. ${ }^{100}$

Several pilot plants have been established in the last five years to produce ethanol from cellulosic material. A Japanese plant uses wood to produce ethanol, and a commercial operation in the United States converts wood waste material into ethanol. A plant has been established in the Netherlands to produce ethanol from wheat chaff and other wastes, and another in Germany to produce ethanol from wood waste. ${ }^{101}$ Several pilot plants have been established in the United States, mostly by Abengoa Bioenergy, a company that already owns existing (first generation) ethanol processing plants. ${ }^{102}$

In August 2009, the Australian Government announced funding of \$15 million for a research and development program for second generation biofuels. Seven projects are funded, including the production of biofuel from algae, wood, bagasse and sustainable sugarcane. ${ }^{103}$ In early 2011, the United States Government offered \$650 million in loan guarantees (i.e. the Government commits to paying a portion of a private loan in the event that a company defaults on that loan) for second generation biofuel production. Four companies will receive the loan guarantees to establish refineries capable of producing biofuel from waste products.

\footnotetext{
${ }^{99}$ FAO, above n 97, 30.

100 International Energy Agency, Biofuels for Transport: An International Perspective. International Energy Agency, Paris, 2004, 79.

${ }^{101}$ International Panel for Sustainable Resource Management, above n 19, 53.

102 International Energy Agency (IEA), From $1^{\text {st }}$ to $2^{\text {nd }}$ Generation Biofuel Technologies: An Overview of Current Industry and R\&D Activities. OECD/IEA, Paris, 2008, 67. Provides a complete description of second generation biofuel pilot plants and other demonstration projects.

${ }^{103}$ Martin Ferguson "Second Generation Biofuels Funding Announced" Australian Government Media Release 5 August 2009.
} 
This investment follows a $\$ 1.2$ billion aid package, announced in 2007 and to be delivered in partnership between the US Government and industry, to increase the cost-effectiveness of cellulosic ethanol production. ${ }^{104}$

Despite the initiatives described above, most current policies are still aimed at supporting first generation biofuels, and few support policies specifically relate to second generation biofuel or other types of biofuel that will provide the greatest environmental benefit. The relatively high cost of support for first generation biofuels may hinder the development of second generation biofuels. Although the investment into biofuels research and development in general is promising, it will have little effect in achieving environmental goals if the support policies are inconsistent with other policies, such as biofuel certification.

\section{$2 \quad$ Current policies relating to tariffs and subsidies for biofuels}

Governments can directly support their domestic biofuel production through two main mechanisms: by providing subsidies to domestic producers or by applying import tax to protect the domestic industry from foreign competition. Each type of support can affect the pattern of biofuel production and trade, and is usually justified on the grounds that support is needed for the establishment and growth of a new industry. In Brazil, for example, government subsidization - in the form of investment in infrastructure, loans to producers and subsidies at the fuel pump - was crucial to the establishment of an economically viable bioethanol industry. ${ }^{105}$

In most cases - and with the exception of the support for second generation biofuels described in the previous section - government support for biofuels is not linked to the sustainable production of biofuels, or to their potential to reduce greenhouse gas emissions. In some cases, government support promotes the production of less efficient or environmentally damaging biofuels; some examples are given below. There is potential for governments to use support mechanisms such as subsidies to encourage the sustainable production of biofuels, and care must be taken to ensure that support mechanisms do not favour inefficient technologies, feedstocks or methods of production, or obstruct international trade.

\footnotetext{
${ }^{104}$ BusinessGreen. “Us Offers \$650m in Loan Guarantees For Second-Generation Biofuel” BusinessGreen 24 January 2011. Article can be found at: http://www.businessgreen.com/bg/news/1938913/offers-usd650m-loanguarantees-generation-biofuel (Accessed 20 October 2011).

${ }^{105}$ Howse, above n 24, 15.
} 
Several countries provide direct subsidies to the production of biofuels. For example, the United States provides tax credits to blenders according to the amount of ethanol or biodiesel they blend with gasoline or petroleum diesel. As the tax credit is awarded without limit, the level of biofuel subsidies is growing rapidly, and is expected to reach a total of up to US\$11 billion per year. ${ }^{106}$

Subsidies can also be applied to biofuel feedstocks. Corn is the main feedstock used for ethanol production in the United States, and benefits from subsidies amounting to \$US8.3 billion in 2004 through grants, loans and loan guarantees. ${ }^{107}$ The subsidisation of corn-based ethanol production in the United States has been criticized for several reasons. First, there is concern that incentives to divert corn crops to ethanol production could drive up the cost of food commodities. The production of ethanol from corn is not cost-effective, compared to ethanol from other feedstocks, and additionally the energy yield and potential for greenhouse gas savings is lower for corn-based ethanol than for other types, particularly ethanol produced from sugar cane or cellulosic ethanol. ${ }^{108}$ For example, the cost of producing ethanol from corn in the United States is estimated to be US $\$ 1.03$ per gallon, compared to the cost of Brazilian sugar cane ethanol, which is estimated to be US\$0.81 per gallon and uses less energy in the conversion process. ${ }^{109}$

Tariffs on imported products can be a form of government support to domestic industry when the tariff inflates the price of the imported commodity, making the domestically produced product more attractive. The European Union protects the domestic biofuel market mainly by applying tariffs. Imported ethanol falls under the customs classification of "non-denatured alcohol", with a tariff of $€ 0.192 /$ litre. ${ }^{110}$ However, preferential treatment is accorded to some countries as a result of trade agreements. For example, ethanol produced in African, Caribbean, Pacific and some Central and South American countries can be imported into Europe duty free. Some countries that are leading sugar cane ethanol producers (including Brazil), or have the potential to become so (such as Thailand, Mexico and South Africa), do not have preferential tariff rates for ethanol. ${ }^{111}$ The

\footnotetext{
${ }^{106}$ Doornbosch, above n 23, 26.

107 Marcos Jank, Geraldine Kutas, Luiz Fernando do Amaral and Andre Nassar, EU and U.S. Policies on Biofuels: Potential Impacts on Developing Countries. The German Marshall Fund of the United States, Washington, 2007, 24.

${ }^{108}$ Kurz, above n 8, 391.

109 de Lima Mantilla, above n 49, 210.

110 Jank, above n 107, 21.

111 Ibid., 21.
} 
United States applies a tariff of US\$0.143 per litre on ethanol imported for use as fuel which effectively curbs the import of Brazilian ethanol - and this tariff has recently been criticised for unjustifiably protecting the domestic industry. ${ }^{112}$

Biofuels vary widely - according to feedstock, method of production, and geographical area of production - in their impact on greenhouse gas emissions, energy efficiency, environmental affects and cost of production. The existence of tariffs that protect a domestic industry or give preferential rates to some countries could have the effect of favouring the production of biofuels from crops that are not the most efficient or environmentally sustainable. It has been estimated that the elimination of import tariffs for biofuels could have a significant impact on the greenhouse gas savings, as a result of a reduction in production of grain based ethanol in favour of sugar cane based ethanol. ${ }^{113}$

Additionally, there is little international consistency in supporting environmentally sustainable biofuels. Although some countries may implement domestic policies to support second generation biofuels, if these biofuels are then exported, the differing import tariffs between types of biofuels may not encourage the production of biofuel from feedstock and production locations that result in the greatest greenhouse gas reductions. ${ }^{114}$ It has been suggested that policy support packages should take an integrated - and where possible an internationally consistent - approach. Support mechanisms for second generation biofuels should be part of a comprehensive strategy. ${ }^{115}$

\section{B Certification schemes for the sustainable production of biofuels}

Setting standards and establishing certification schemes are possible strategies that can help ensure that biofuels are produced in a sustainable manner. Recently, scientists, policy makers and other interested individuals and organisations have recognised the benefits of certification schemes and standards for biofuel production, and have been pushing for their development. ${ }^{116}$ Most proponents of such schemes agree that a set of environmental, social and economic criteria should be included in a biofuels certification system. Currently, some governments, biofuel producers and organisations are preparing such criteria, and have started to bring them into practice. It has been suggested that such criteria would include

\footnotetext{
112 Kurz, above n 8, 406.

${ }^{113}$ International Panel for Sustainable Resource Management, above n 19, 88.

${ }^{114}$ FAO, above n 97, 93.

${ }_{115}$ International Energy Agency, above n 102, 97.

${ }^{116}$ van Dam, above n 33, 750.
} 
levels of greenhouse gas saving, the preservation of biodiversity and the use of efficient feedstocks, and a failure to meet the criteria would result in penalties such as exclusion from tax breaks and use in biofuel blending obligations or national targets. Although there seems to be a general agreement that it is important to include economic, social and environmental criteria in the development of a biofuels certification system, differences are also visible in the criteria that have been developed by various parties. Several critics have stated that better international coordination is needed to avoid the proliferation of standards and to provide a clearer direction in the approach to be taken. ${ }^{117}$

The International Organization for Standardization (ISO) defines standards as “documented agreements containing technical specifications or other precise criteria to be used consistently as rules, guidelines or definitions, to ensure that materials, products, processes and services are fit for their purpose". ${ }^{118}$ The WTO defines "standards" as rules, guidelines or characteristics for products with which compliance is not mandatory. This is in contrast to "technical regulations", with which compliance is mandatory. ${ }^{119}$

Certification includes an independent assessment of the quality of a product, using a set of predetermined requirements, regulations or standards. A third-party assessor provides a written declaration that the product conforms to certain criteria, providing assurance to the consumer that it has certain qualities (for example, the product is safe, healthy, high quality, environmentally friendly, etc.). In this way, certification schemes - although they can involve significant costs - can be used by manufacturers and retailers as a method of marketing a product. $^{120}$ A government can require goods to be certified in order to meet a policy goal, such as ensuring that goods are safe for consumer use. Criteria must be measurable, and often indicators or verifiers are needed to describe how the criteria are to be measured. Supporting documentation is part of the certification scheme. For example, applicants may need to submit documents to demonstrate conformity with the criteria.

The major players in biofuels certification schemes include national and regional governments, international organisations including NGOs, and private companies. Each category of stakeholder will have differing interests and aims in developing a certification scheme. For example, national governments may view certification as a way to promote

\footnotetext{
${ }^{117}$ For example see van Dam, above n 33, 749; Mol, above n 39, 52.

${ }^{118}$ ISO Guide 2: 2004. International Standards Organization, Geneva, 2004.

${ }^{119}$ TBT Agreement, above n 5, Annex 1.

${ }^{120}$ Iris Lewandowski and Andre Faaij, Steps Towards the Development of a Certification System for Sustainable Bio-energy Trade. Copernicus Institute of Sustainable Development and Innovation, The Netherlands, $2004,6$.
} 
sustainable production and consumption of biofuels, and as a way to meet their obligations under international environmental agreements. NGOs may also be interested in biofuels as a development opportunity for developing countries, and ensuring consumer awareness of environmental issues. Private companies are likely to view certification as a marketing tool and a way to ensure continued market access.

Government-established certification schemes or sustainability requirements for the production and use of biofuel are linked in a conditional manner to financial incentives to promote sustainably produced biofuels. These initiatives are described in detail in the section below.

A number of organisations and private companies have also initiated certification schemes for the sustainable production of biofuels. Some of the major schemes, particularly those linked to government policies, are described in the following section, although most of the private biofuels certification initiatives are not covered comprehensively in this dissertation.

\section{$1 \quad$ European Commission}

The European Commission (EC) has been active in encouraging renewable energy consumption in European countries, including setting mandatory targets for biofuels. Initially, the focus was on stimulating the use of biofuels with the purpose of reducing greenhouse gas emissions. Only recently, following pressure from NGOs, scientists and some member states, has the EC considered the broader sustainability issues associated with biofuels. The European biofuel policy is complex; it involves regulations directly related to biofuels, and also regulations and directives related more broadly to energy and fuel quality.

Directive 2003/30 - the "Biofuels Directive" set a non-binding target of 5.75 per cent biofuels in transportation fuels by 2010 in each member state, with the purpose of achieving climate change commitments and promoting renewable sources of energy. ${ }^{121}$ The Directive did not include any sustainability criteria, but mandated that the EC report every two years on the environmental impact of biofuel use and the effectiveness in meeting climate change commitments. ${ }^{122}$ To encourage member states to implement the Directive and achieve the

\footnotetext{
${ }^{121}$ Directive 2003/30/EC of the European Parliament and of the Council on the promotion of the use of biofuels or other renewable fuels for transport, 8 May 2003, Article 1.

${ }^{122}$ Ibid, Article 4.2.
} 
target, the Energy Tax Directive authorises European countries to introduce tax reductions and exemptions for biofuels. ${ }^{123}$

The Biofuels Directive has elicited concern about the negative environmental effects of biofuel production. ${ }^{124}$ This led to the 2003 Directive being updated and the development of a more mature European biofuels policy. This approach was confirmed with the publication in January 2007 of an "Energy Policy for Europe". ${ }^{125}$ This included a binding 20 per cent target for consumption of renewable energy by 2020, and a binding 10 per cent target for biofuels energy share in transport by 2020. The biofuel mandate was subject to production being sustainable, the availability of second generation biofuels and the amendment of the Fuel Quality Directive (see below).

The 1998 Fuel Quality Directive sets standards for fuels, and links in with biofuel policy through a 2007 proposal to include a the measurement of greenhouse gas emissions for fuels supplied in Europe. The proposal also includes incentives for biofuel blending, such as a requirement to reduce greenhouse gas emissions by one per cent per year from 2011, and increasing the ethanol blending requirement. ${ }^{126}$ The revised Fuel Quality Directive was adopted in 2009 at the same time as the Renewable Energy Directive (described below), and contains the same sustainability criteria. ${ }^{127}$

In April 2009, the EC released the Renewable Energy Directive (RED). The RED states that member countries should achieve a target of 10 per cent renewable energy use in transport fuels by 2020. This will be achieved primarily through the use of biofuels, and is subject to sustainable biofuels becoming available. The RED quotes the need to comply with the Kyoto Protocol and UN Framework Convention on Climate Change in reducing

${ }^{123}$ Directive 2003/96/EC of the European Parliament and of the Council restructuring the Community framework for the taxation of energy products and electricity, 27 October 2003.

${ }^{124}$ Stephanie Switzer and Joseph McMahon, "EU biofuels policy - raising the question of WTO compatibility" (2010) 26 UCD Working Papers in Law, Criminology and Socio-legal Studies, 3.

${ }^{125}$ Commission of the European Communities, Communication from the Commission: An Energy Policy for Europe. Brussels, 10.1.2007 COM(2007) 1.

${ }^{126}$ Commission of the European Communities, Proposal for a Directive of the European Parliament and of the Council amending Directive 98/70/EC as regards the specification of petrol, diesel and gas-oil and introducing a mechanism to monitor and the introduction of a mechanism to monitor and reduce greenhouse gas emissions from the use of road transport fuels and amending Council Directive 1999/32/EC, as regards the specification of fuel used by inland waterway vessels and repealing Directive 93/12/EEC. Brussels, 31.1.2007 COM(2007) 18.

127 Directive 2009/30/EC of the European Parliament and of the Council amending Directive 98/ 70/ EC as regards the specification of petrol, diesel and gas-oil and introducing a mechanism to monitor and reduce greenhouse gas emissions and amending Council Directive 1999/32/EC as regards the specification of fuel used by inland waterway vessels and repealing Directive 93/12/EEC, 23 A pril 2009. 
greenhouse gas emissions, and also the need for security of energy supply, technological development and regional development. ${ }^{128}$ The RED also states that "it is essential to develop and fulfil effective sustainability criteria for biofuels and ensure the commercial availability of second-generation biofuels.” 129

To this effect, the RED itself contains criteria to assess the sustainability of biofuels and other bioliquids. The criteria relate to greenhouse gas emissions, biodiversity and carbon stock. In particular:

- The use of biofuels should lead to greenhouse gas savings of at least 35 per cent (increasing to 60 per cent by 2018), calculated over the lifecycle of the product. The RED sets down the methodology for calculating greenhouse gas savings. ${ }^{130}$

- Land of high biodiversity value, of high carbon stock, or peatland, should not be used to produce biofuels. ${ }^{131}$

The RED underlines the need to assess the possible impacts of biofuel production on agricultural food products and further assessment should be made of the environmental and social consequences of the production and consumption of biofuels. However, the RED does not contain specific criteria relating to these possible impacts, but only requires monitoring and reporting. If the monitoring shows that biofuel production is having social impact or an impact on food security, there is no guidance in the RED on what is considered significant, or what actions should be taken in response. The exclusion of criteria to address these broader issues has already resulted in tensions with some member countries and other organisations. $^{132}$

Biofuels that do not meet the sustainability requirements will not count toward national biofuels targets under the RED or revised Fuel Quality Directive, nor will they qualify for financial incentives. This applies to biofuels both produced within the EU and biofuels imported from outside the EU. The RED encourages European countries to develop national schemes to certify against the sustainability criteria, as well as to develop bilateral or

\footnotetext{
${ }^{128}$ Directive 2009/28/EC of the European Parliament and of the Council on the promotion of the use of energy from renewable sources and amending and subsequently repealing Directives 2001/77/EC and 2003/30/EC, 23 April 2009 (Hereafter Renewable Energy Directive), paragraph 1.

${ }^{129}$ Ibid, Article 17 paragraph 7.

${ }^{130}$ Ibid, Article 17 paragraph 2.

${ }^{131}$ Ibid, Article 17, paragraphs 3,4,5.

${ }^{132}$ Zarrilli, above n 92, 4.
} 
multilateral agreements with third countries. ${ }^{133}$ A number of countries, including Germany, the UK and Switzerland have taken the initiative to develop certification schemes. The RED should ensure a certain degree of consistency between European certification schemes, particularly as is states that sustainability criteria not contained in the RED cannot be used to deny the eligibility of biofuels for national targets and financial support. ${ }^{134}$

The RED attempts to cover the major sustainability concerns raised by stakeholders, and some of the criteria contain clear and measurable requirements, for example the criteria relating to greenhouse gas emissions provides minimum requirements, clear definitions and a methodology for measuring life-cycle greenhouse gas emissions from biofuels. Other criteria contained in the RED are less clear and measurable, for example the reporting requirements for the impact of biofuels on food production. This may require revision at a later date as the link between biofuels and international food security becomes better described.

\section{Germany}

Germany, a world leader in biodiesel production, encourages the use of biofuels through the Biofuels Quota Act 2007 which introduces a quota for the blending of biofuels into petrol and diesel. The Act aims to increase the share of biofuels to eight per cent from 2015. ${ }^{135}$ The Act also allows the Government to establish sustainability criteria for biofuels which are to be met for biofuels to be eligible for the quota and to benefit from tax reductions. Tax relief for eligible biofuels is provided for under The Energy Tax Act. ${ }^{136}$ Germany has also released an Ordinance for the sustainable production of bioliquids for electricity production, which sets the same sustainability criteria for bioliquid production, and which must be met for the payment framework outlined in the Renewable Energy Sources Act to apply. ${ }^{137}$

The German Government has implemented the European RED into national law, by means of a sustainability Ordinance for biofuels. ${ }^{138}$ The Ordinance sets down sustainability criteria for biofuel production. The definitions and methodology for measuring and reporting

\footnotetext{
${ }^{133}$ Renewable Energy Directive, above n 128, paragraph 74.

${ }^{134}$ Ibid, Article 15.

${ }^{135}$ An English translation of the Biofuels Quota Act is not available, therefore information in this section is drawn from the description in Zarrili, above n 92, 8.

136 Germany - Notification to the Committee on Technical Barriers to Trade (30 October 2009) G/TBT/N/DEU/10, 6 .

137 Ordinance on requirements pertaining to sustainable production of bioliquids for electricity productions (Biomassestrom-Nachhaltigkeitsverordnung (BioSt-NachV)), 15 December 2008.

${ }^{138}$ Biokraftstoff-Nachhaltigkeitsverordnung - BiokraftNachV, December 2009
} 
against the criteria follow those of the RED, and therefore have the same strengths and weaknesses. The key requirements relate to:

- greenhouse gas savings on a life-cycle basis, which must be 30 per cent, increasing to 40 per cent from 2011;

- protection of natural habitats;

- $\quad$ sustainable cultivation of agricultural land and sustainable land use. ${ }^{139}$

Consistent with the RED, the Ordinance does not include criteria for the impact of biofuels on food production, indirect land use changes, or social impacts.

The criteria apply to both domestically produced and imported biofuels. The German Government notified the WTO Committee on Technical Barriers to Trade of both the biofuels sustainability Ordinance (in October 2009) and the Ordinance for the sustainable production of bioliquids for electricity (in July 2009). ${ }^{140}$ The notifications outline the purpose and aim of the sustainability requirements, and invite comments from members.

The implementation of the sustainability Ordinances is supported by research projects undertaken by governmental and industry organisations. For example, the German farmer's association, the agricultural traders association, oilseed growers, German bioethanol producers and the UFOP (Union zur Förderung von Oel und Proteinpflanzen) are developing a certification body for domestic producers. ${ }^{141}$ Additionally, a project supported by the German Federal Agriculture Ministry has developed a sustainability certificate. The system developed has been approved by German authorities as the first certification system for sustainable biofuel following the sustainability ordinance for biofuels. ${ }^{142}$

\section{The Netherlands}

The Dutch Government has set a mandatory quota for the share of fuel sales in the Netherlands which must come from biofuels, under the Transport Biofuels Act 2007. Initially, the quota was set to conform to the European Biofuel Directive 2003, at 5.75 per cent from 2010. However, due to the public concerns with sustainable production of biofuels,

\footnotetext{
${ }^{139}$ Zarrilli, above n 92, 8.

${ }^{140}$ TBT Notification, above n 161; Germany - Notification to the Committee on Technical Barriers to Trade (15 July 2009) G/TBT/N/DEU/9.

${ }^{141}$ UFOP-Information. Germany's Biodiesel Sector Has Now to Document Its Sustainability. Union zur Förderung von Oel- und Proteinpflanzen e. V., Berlin, 2010, 2.

${ }^{142}$ Ibid, 3.
} 
this was reduced to 2 per cent in 2007, rising to 4 per cent from 2010. The Transport Biofuels Act also allows the Dutch Government to set additional criteria concerning sustainability. ${ }^{143}$

The Dutch Government sought advice on biofuels sustainability criteria from an independent project group for Sustainable Biomass Production (the Cramer Commission). The Cramer Commission produced a report in July 2006 outlining criteria in a framework of six sustainability themes: greenhouse gas emissions, competition with food, biodiversity, environment, prosperity and social well being. Following on from the six themes, criteria, indicators and reporting obligations on the company level and national level were formulated. ${ }^{144}$ The outcomes of the Cramer Commission have been highly influential in the development of other certification schemes and sustainability criteria, including the European RED. The Commission proposed that the sustainability criteria should be incorporated into the national policies on biofuels, including incentives for compliance with the criteria. ${ }^{145}$ The Dutch Government intends to implement a biofuels sustainability policy, focusing on sustainable production, development of second generation biofuels and strengthening international cooperation. ${ }^{146}$ The consistency or otherwise of the Dutch policy with other European biofuels policies remains to be seen, but if it is based on the RED and Cramer Commission themes, then it should be comparable.

\section{$4 \quad$ United Kingdom (UK)}

The United Kingdom has introduced a policy to ensure that biofuels are included in UK transport fuels. The Renewable Transport Fuel Obligation (RTFO) Order 2007 requires transport fuel suppliers to ensure that a percentage of fuel is from a renewable source. ${ }^{147}$ The percentage was initially set at 5 per cent, but reduced in 2009 (to 3.63 per cent from April 2010, and rising to 5.26 per cent from 2013; RTFO Amendment Order 2009) in response to uncertainties about the environmental impact of biofuel production. The RTFO aims to reduce greenhouse gas emissions from transportation fuels by about 2.6 - 3.0 million tons of $\mathrm{CO}_{2}$ per year. ${ }^{148}$ This is to be achieved by issuing tradable certificates to fuel suppliers after

\footnotetext{
143 SenterNovem http://www.senternovem.nl/english/ (accessed 7 November 2010).

144 Project Group Sustainable Production of Biomass, Criteria for Sustainable Biomass Production. Energy Transition Taskforce, The Netherlands, 2006, ii.

145 Ibid, iii.

146 SenterNovem, above n 143 (accessed 7 November).

147 The Renewable Transport Fuels Obligations Order 2007. Transport Energy Sustainable and Renewable Fuels 2007, paragraph 4.

${ }^{148}$ Explanatory Memorandum to the Renewable Transport Fuel Obligations Order 2007, paragraph 7.1.
} 
reporting volumes of fuels from a renewable source. If a supplier has insufficient certificates to meet the obligation, it may pay a buyout price. ${ }^{149}$

The RTFO also contains a requirement for suppliers to report on the greenhouse gas savings and sustainability of biofuels purchased. ${ }^{150}$ Sustainability standards have been developed in cooperation with the Dutch Government; it is not yet mandatory for suppliers to meet a standard, but only to report against it and failure to report makes the supplier ineligible for RTFO certificates. In the longer term, there is scope for certificates to be directly linked to suppliers meeting sustainability criteria or greenhouse gas savings.

The UK sustainability requirements, against which fuel suppliers report, take a "metastandard” approach. This approach sets basic requirements, and then builds on existing standards and certification schemes for biofuels and other biomass, and assesses if a particular scheme meets the basic requirements set by the RTFO. This approach minimises the cost and administration of certification of biofuels. Existing schemes can either meet the full RTFO requirements, or qualify for some of the sustainability criteria of the RTFO, with additional audits of the criteria that are not met. So far, no certification scheme has met the full RTFO meta-standard for both environmental and social requirements. ${ }^{151}$

The UK and Dutch Governments are cooperating on the development of sustainability criteria in an effort to harmonise certification scheme design across the EU. ${ }^{152}$ Therefore, the sustainability principles in the RTFO parallel those that were adopted by the Cramer Commission, and relate to greenhouse gas savings, biodiversity, soil quality, water quality and quantity and air pollution. There are also social criteria which relate to child labour, freedom of association, discrimination, health and safety, forced labour, wages and working hours, contracts and subcontractors and land rights. The RTFO sets "default factors" for greenhouse gas savings for types of feedstocks, countries and processes. The default factors are used when insufficient information is supplied to determine greenhouse gas savings for a particular supplier, and they are deliberately conservative to provide an incentive for suppliers to find detailed information about the production of their biofuels. ${ }^{153}$

\footnotetext{
${ }^{149}$ Ibid, paragraph 2.1

150 The Renewable Transport Fuels Obligations Order 2007, above n 147, 13(4).

${ }^{151}$ Endres, above n 93, 85.

152 van Dam, above n 33, 754.

${ }^{153}$ Renewable Fuels Agency http://www.renewablefuelsagency.gov.uk (Accessed 9 November 2011).
} 
The Renewable Fuels Agency (RFA), which is responsible for governing the RTFO, is also required to monitor commodity markets to determine if growing biofuel demand is having an effect on food security. The RFA also assesses other indirect impacts of biofuels, such as land use change. These assessments form an annual report from the RFA to Parliament.

The strength of the RTFO is in its meta-standard approach, which allows flexibility and greater consideration of differences between local environments and production systems. It also improves harmonisation, if the RFA accepts certification schemes from other importing countries as qualifying. It also places most of the regulatory burden on the RFA, rather than the producer, which would be of particular benefit to producers in developing countries which may find the regulations associated with biofuels to be overly burdensome. The disadvantage of the RTFO approach is that it results in lack of clarity for some criteria. For example, the method for setting default factors for greenhouse gas savings is unclear, and may disadvantage the producers who are not able to supply information to prove that greenhouse gas savings are greater than the default value.

\section{$5 \quad$ Switzerland}

In Switzerland, transportation fuels including biofuel are taxed according to the Mineral Oil Taxation Law 1996. ${ }^{154}$ With the aim of meeting requirements (under the Kyoto protocol) to reduce CO2 emissions, the Mineral Oil Taxation Law was amended in 2008 to give tax benefits to biofuels, both imported and domestically produced. The tax exemption however, only applies to biofuels which meet certain environmental and social criteria. Unlike other countries that are promoting biofuel use, Switzerland has not introduced any requirements for a percentage of transportation fuel to be from biofuels, or any blending requirements. Importers of biofuels must prove that the biofuel has a positive global ecological effect, and that it has been produced under socially acceptable conditions. Specifically, the amended Law states that biofuels must generate 40 per cent less greenhouse gas than gasoline, calculated on a life-cycle basis, they must not damage the environment in ways that are greater than the environmental damage caused by gasoline, they must not

\footnotetext{
${ }^{154}$ Mineral Oil Taxation Law, 21 June 1996. An English translation of the Law is not available, therefore information is taken from secondary sources as cited.
} 
damage tropical forest or endanger biodiversity, and they must be produced under socially acceptable conditions, according to the International Labour Organization. ${ }^{155}$

The Mineral Oil Taxation Ordinance was also amended in 2008, to reflect the changes to the new Mineral Oil Taxation Law. The new Ordinance specifies the list of acceptable fuels from renewable raw materials, and the terms regarding proof of positive ecological effect and socially acceptable production conditions. Controversially, it is considered that biofuels from palm oil, soybeans and cereals do not comply with the minimum requirements. A new Ordinance was also approved in 2008 on the adjustment of the tax rates of gasoline (Gasoline Tax Rate Adjustment Ordinance 2008). This Ordinance introduces higher taxation rates for gasoline, to offset the loss of revenue caused by the tax-exemption of biofuels. The tax rate is to be periodically adjusted in response to changing quantities of gasoline and biofuels. $^{156}$

The Swiss Department of Environment, Transport, Energy and Communications (DETEC) has released regulations to set down how importers of biofuels are to meet the criteria to qualify for the tax exemption. Manufacturers or importers must submit documentation to describe the entire process of fuel production to DETEC, which then conducts a life-cycle assessment to evaluate greenhouse gas emissions and ecological impact. ${ }^{157}$ In many ways, this method of assessment is considered to be less costly and onerous to importers and producers than other proposed certification schemes, as the information is relatively easy to provide, and the assessment is the responsibility of the Government. ${ }^{158}$

\section{$6 \quad$ Brazil}

The Brazilian ethanol program, initiated in 1975, is now well established. The Brazilian National Alcohol Programme, or Proalcool, was created in 1975 by Decree No. 76.953, and included incentives for ethanol production such as subsidies and tax breaks, mandatory ethanol blending with gasoline, and the adaptation of vehicles to run on pure ethanol. The mandatory percentage of ethanol to be blended with gasoline is now set at 25

\footnotetext{
${ }^{155}$ Ronald Steenblick, Christopher Beaton and Juan Simon, Biofuels - At What Cost? Government Support for Ethanol and Biodiesel in Switzerland: 2008 Update. International Institute for Sustainable Development, Geneva, 2008, 35-36.

${ }^{156}$ Biofuels Platform http://www.biofuels-platform.ch/en/infos/ch-limpmin.php. (Accessed 12 November 2010).

${ }^{157}$ Ibid, accessed 12 November 2010.

158 Steenblick, above n 155, 37.
} 
per cent. ${ }^{159}$ In 2004 Brazil initiated a biodiesel program along similar lines. Law No. 11.097 included a 2 per cent addition of biodiesel to petrol and diesel, which was initially voluntary but became mandatory in 2008. The required addition of biodiesel will rise to 5 per cent by 2013. ${ }^{160}$

Brazil has initiated activities to ensure the sustainability of biofuels produced domestically. The activities have been brought about partly in response to concerns about the environmental effects of the rapidly expanding sugarcane production, but also to ensure continued access to European markets that are introducing sustainability criteria for biofuels. ${ }^{161}$

The Brazilian Government has tasked the National Institute of Meteorology, Standardization and Industrial Quality (Inmetro) with developing a voluntary certification scheme. It has so far developed principles and indicators relating to compliance with environmental and labour laws, working conditions, sustainable use of natural resources, biodiversity protection, water, soil and air protection, and socioeconomic development. ${ }^{162}$ Given the Brazilian President's statement that biofuels produced in Brazil will conform to environmental and social standards through a certification scheme, it is possible that the voluntary scheme developed by Inmetro could become mandatory in the future. ${ }^{163}$ If the certification scheme is developed specifically to meet European requirements, problems could arise if other countries importing Brazilian ethanol develop certification schemes that contain different requirements.

Another government initiative is the Social Fuel Seal, part of the biodiesel program. In an effort to address regional social inequalities, the Social Fuel Seal allows (Brazilian) producers to obtain tax benefits if biofuel feedstock is obtained from family farmers under a legally binding agreement. ${ }^{164}$

\footnotetext{
159 World Resources Institute http://projects.wri.org/sd-pams-database/brazil/national-alcohol-programproalcool (accessed 12 November 2010).

${ }^{160}$ Zarrilli, above n 92, 14.

161 Jonathan Stearns EU Warns Brazil on Environmental Impact of Biofuels (Update 3). Bloomberg, 5 July 2007.

${ }_{162}$ Zarrilli, above n 92, 9.

${ }^{163}$ Stearns, above n 161.

${ }^{164}$ van Dam, above n 33, 755.
} 
The use of renewable fuels in the United States is governed by the Energy Independence and Security Act 2007 (EISA). The EISA modifies the Renewable Fuel Standard to require a minimum annual level of renewable fuels use in transportation fuel of 9 billion gallons in 2008, and rising to 36 billion gallons in 2022. ${ }^{165}$ The United States also provides tax exemptions and subsidies for the blending of ethanol in gasoline, introduced through the Energy Tax Act 1978, and for biodiesel, introduced through the Conservation Reauthorisation Act 1998. ${ }^{166}$

The EISA was created with the purpose of increasing energy efficiency and independence, but it also addresses greenhouse gas emissions and sustainability issues. The definition of "renewable fuel" in the EISA includes factors on reduction of greenhouse gas emissions and land use. For example, renewable fuel feedstock cannot be harvested from land that is newly cleared or cultivated. ${ }^{167}$ Different types of biofuels are also defined, including conventional biofuels which reduce greenhouse gas emissions by at least 20 per cent, advanced biofuels and biodiesel which reduce greenhouse gas emissions by at least 50 per cent, and cellulosic biofuels which reduce greenhouse gas emissions by at least 60 per cent (percentage calculated from baseline life cycle). The different types of biofuel are specified in the required volume of renewable fuels; by 2022, 21 billion of the renewable fuel requirement is to come from advanced or cellulosic biofuel. This law effectively puts a cap on the use of corn-based ethanol, which is considered to be less efficient than other types of biofuel, to fulfil the renewable fuel requirement.

The Environmental Protection Agency (EPA) is responsible for developing regulations for the sustainable production of renewable fuels. Draft regulations relate to greenhouse gas emissions, and the impact of production on water, air and soil, and propose several alternatives for ensuring compliance with the land-use provisions in the EISA. ${ }^{168}$

\section{$8 \quad$ Non-Governmental bodies}

Although certification schemes established by non-governmental organisations are not the focus of this dissertation, it is useful to outline the ones being developed by prominent international organisations. The certification schemes developed by these organisations

165 Fred Sissine, Energy Independence and Security Act of 2007: A Summary of Major Provisions. Congressional Research Service, 2007, 1.

${ }^{166}$ Al-Riffai, above n 48, 111.

${ }^{167}$ Sissine, above n $165,5$.

${ }^{168}$ Endres, above n 93, 76. 
could, at some stage, be adopted or used as a basis for national policies. These organisations could also potentially play an important role in international coordination and provide mechanisms for harmonisation. Some have already taken steps in this direction, and have established links between different stakeholders.

\section{(a) United Nations (UN)}

Biofuels are of interest to the UN due to their possibilities to stimulate development, and they bring both risks and possibilities in achieving the Millennium Development Goals. Several UN bodies have initiated biofuel-related activities, and these are co-ordinated through the UN Biofuels Initiative (UNBI). The various UN bodies working on biofuels include:

- The United Nations Conference on Trade and Development (UNCTAD) Biofuels Initiative which provides support to developing countries which are considering developing a biofuels program, in partnership with other UN bodies. The issue of sustainability and certification of biofuels has been raised in UNCTAD meetings and reports. ${ }^{169}$

- The Food and Agriculture Organization (FAO) has established the International Bioenergy Platform (IBEP), which provides advice on developing bioenergy policies, with a particular focus on the impacts of bioenergy on food security and sustainable development. The IBEP is working towards an international scheme for developing certification principles, methodologies, criteria and indicators. ${ }^{170}$

- The United Nations Environment Programme (UNEP) is involved in multistakeholder approaches on the sustainable production of biofuels, including the Roundtable on Sustainable Biofuels and the Global Bioenergy Partnership (both described below).

\section{(b) Global Bioenergy Partnership}

The Global Bioenergy Partnership (GBEP) was established by the G8 with the purpose of identifying and implementing bilateral or multilateral projects for sustainable bioenergy production. The GBEP has identified a set of sustainability categories for biofuel

\footnotetext{
169 Zarrilli, above n 92, 16. For examples see the "Report of the expert meeting on green and renewable technologies as energy solutions for rural development”, Geneva 2010; Conference on biofuels: An option for a less carbon-intensive economy: UNCTAD XII pre-event, Brazil 2007. Meeting papers are available on the UNCTAD website: www.unctad.org. Accessed October 2011.

${ }^{170}$ van Dam, above n 33, 761.
} 
production which covers the life cycle of production and use, and is working on establishing a methodological framework for calculating lifecycle greenhouse gas emissions from biofuels. ${ }^{171}$

\section{(c) The IEA Bioenergy Taskforce 40}

The IEA has established a taskforce to develop a platform for international assessment of existing bioenergy sustainability standards. The aim of this group is support the development of bioenergy markets, including international trade. The taskforce has published their review of certification schemes, including the limitations and difficulties in implementation. The group has suggested an international agreement on sustainability criteria, but acknowledges the time that would be needed to negotiate such an agreement. ${ }^{172}$

\section{(d) Roundtable Groups}

The rapid increase in biofuel production and use has triggered the establishment of Roundtable groups, which represent all stakeholders in the supply chain, as well as academics, environmentalists, NGOs and intergovernmental organisations. Roundtable initiatives include the Roundtable on Sustainable Biofuels (RSB), the Roundtable on Sustainable Palm Oil (RSPO), and the Roundtable on Responsible Soy (RTRS).

The RSB, established by the Ecole Polytechnique Fédérale de Lausanne in 2007, aims to gain global consensus on the criteria for sustainable biofuel production, building on national and commodity specific criteria, and to build a voluntary sustainable biofuels standard. ${ }^{173}$ Two drafts of the standard have been released, in 2008 and 2009, for public comment. The standard includes social and environmental sustainability principles, and in July 2011 it was recognised by the European Union as proof of compliance with the RED. ${ }^{174}$

The aims of the RSPO and RTRS are similar - establishing principles and criteria for sustainable production - but for the specific commodities involved. The RSPO has developed a set of 8 principles and 39 criteria for sustainable palm oil production, and has finalised a certification scheme. The RTRS aims to develop criteria for the economically viable, socially equitable and environmentally sustainable production of soy. The group has produced a draft

\footnotetext{
${ }^{171}$ Endres, above n 93, 111-12.

172 Ibid, 112-13.

${ }^{173}$ van Dam, above n 33, 763.

174 Roundtable on Sustainable Biofuels. "RSB Recognaized by the European Union as Proof of Compliance With the Renewable Energy Directive”. Press Release 19 July 2011.
} 
of principles, and is working to produce a set of criteria and indicators based on the principles. $^{175}$

\section{Summary}

Some of the certification schemes described above are well developed and on their way towards implementation; others are still in the negotiation or development stages. The focus of the above section is on government-developed certification schemes designed to encourage the use of sustainably produced biofuels. Although non-certified biofuels may be imported into these countries, it is still necessary for biofuels to meet a standard in order to qualify for benefits. ${ }^{176}$ One common feature of biofuel initiatives is a government requirement to mix a target level of biofuel with fossil fuel for transport, with only certified biofuel qualifying for the target. A supplier or importer of certified biofuel may additionally receive tax relief or favourable tariffs, the ability to sell to the government, or a positive label. Non-certified biofuels would be at a significant disadvantage in these markets.

The schemes that have been developed by other bodies are generally voluntary, but may still impact the market through other means such as marketing through labels and dissemination of information to the public. It is also possible that certification schemes developed by international organisations could be adopted by a national government.

The criteria to be met differ for each certification scheme, although the common criteria relate to the reduction of greenhouse gas emissions and the preservation of biodiversity and sensitive ecological areas. The reduction of greenhouse gas emissions is stated in a measurable manner, with emissions measured on a life-cycle basis and, for the European Union and UK, baseline levels are given for different feedstock. However, it should be noted that the methods used for life-cycle analysis are not necessarily the same for different schemes, and the most appropriate methodology is a subject of debate. Social criteria are not included in all schemes, and where they are included, it is unclear how social standards would be measured and verified.

The review of biofuels policies reveals numerous coordination problems. In many cases, governments have initiated programs to promote biofuel production, with little clarity on the policy goal or intended outcome. Some governments are attempting to address sustainability concerns of biofuel production, mostly through certification, but these efforts

\footnotetext{
${ }^{175}$ Zarrilli, above n 92, p 18-19.

176 The mandatory or voluntary nature of biofuels certification schemes is discussed further in Chapter IV.
} 
could be compromised if other biofuels policies, such as research and development support, tariffs and subsidies are encouraging the production of biofuels that are not energy efficient or that carry significant environmental or social risks. The large number of certification schemes under development by both governmental and non-governmental bodies lack consistency in their criteria, methodology and reporting requirements.

Although there have been some efforts at providing consistency between the various different certification schemes, the current lack of coordination raises a number of concerns. Firstly, producers and exporters of biofuels and biofuel feedstocks will face increasing costs associated with certification, and increasing bureaucratic complexity and regulatory burden. Potential solutions to the lack of international cooperation are beginning to emerge. For example, the RFTO scheme developed by the UK acknowledges the regulatory burden associated with numerous certification initiatives, and addresses this problem through the meta-standard approach. Additionally the European countries have made an effort to harmonise the criteria of the certification schemes, which is evident in the similarities between schemes developed by the UK, Germany and the Netherlands.

A second concern is that the increasing regulations associated with biofuel trade could result in a system that discriminates between domestically produced biofuels and imported biofuels; this is discussed in detail in Chapter IV. The certification initiatives developed by the European Union and Germany both explicitly acknowledge the need for fair trade and compliance with WTO rules; stating that sustainability criteria are to be applied to imported and domestically produced biofuels in a non-discriminatory way. Additionally, some aspects of the sustainable production of biofuels could be addressed through existing international agreements; this possibility is further explored in Chapter V. 


\section{WTO COMPATIBILITY OF BIOFUELS CERTIFICATION}

The previous chapter described biofuels certification schemes that have been developed by governments as a policy response to the sustainability concerns of biofuel production. Although biofuels certification schemes appear to be addressing real and important environmental and social issues, there is also a risk that certification could also be used as a trade barrier, put into place to protect a domestic industry. Policy makers need to ensure that biofuel certification schemes are designed in a way that does not create unnecessary barriers to trade. Biofuels certification schemes have the potential to impact trade, and are subject to WTO rules. This chapter will examine how the WTO agreement and principles contained within it apply to trade in certified biofuels.

The need to meet criteria to qualify for certification can involve significant costs to producers and exporters. Although non-certified biofuels may be traded, the certification schemes could be considered as mandatory for the market in question, in the sense that biofuels need to meet a standard in order to qualify for benefits. Non-certified biofuels would be at a disadvantage in these markets. ${ }^{177}$ If a certification scheme for an exported product results in differential market access conditions, care needs to be given to ensure it does not violate the WTO principle of non-discrimination and does not constitute an unnecessary obstacle to trade. WTO members cannot discriminate between trading partners when applying taxes and subsidies to imported products. Also, imported goods must not be treated less favourably than similar domestically produced goods. Regulations applied to imported products must not be more trade restrictive than necessary.

The criteria to be met differ for each certification scheme, although the common criteria relate to the reduction of greenhouse gas emissions and the preservation of biodiversity and sensitive ecological areas. The reduction of greenhouse gas emissions is stated in a measurable manner, with emissions measured on a life-cycle basis and, for some schemes, baseline levels are given for different feedstock. However, it should be noted that the methods used for life-cycle analysis are not necessarily the same for different schemes, and the most appropriate methodology is a subject of debate. Social criteria such as those relating to working conditions or land rights are not included in all schemes, and where they are included, it is unclear how social standards would be measured and verified.

\footnotetext{
${ }^{177}$ Marsha Echols, Biofuels Certification and the Law of the World Trade Organization. ICTSD Programme on Agricultural Trade and Sustainable Development, Geneva, 2009, pviii.
} 
This chapter focuses on government-developed certification schemes designed to encourage the use of sustainably produced biofuels. Biofuels certification schemes developed by governments are likely to distinguish between products (sustainably-produced and nonsustainably produced biofuels) in a way that would result in differential trade conditions such as market access, tariffs and taxes. The certification scheme could have an effect on trade if the government of the importing country directs compliance by either (1) denying or limiting market access to products that do not meet the certification standards, or (2) applying a different tax or tariff to products that do not meet the certification standards. In this situation, a certification scheme would need to comply with WTO trade regulations. The support mechanisms which would fall under WTO rules include: ${ }^{178}$

- Full or partial tax exemptions or rebates;

- Mandates for the production level of biofuels or a compulsory blending percentage of biofuels with fossil fuels;

- Specified level of biofuel use in government fleets;

- Other measures applied through policy that links support to compliance with technical regulations.

The schemes that have been developed by non-government bodies are generally voluntary, but may still impact the market through other means such as marketing through labels and dissemination of information to the public. ${ }^{179}$ A grey area is the question of whether biofuels certification schemes developed by non-governmental bodies are also covered by the WTO. If certification is considered to be a voluntary marketing scheme, then it would fall outside the scope of WTO rules. ${ }^{180}$ However even certification schemes that are being developed with the intention of being voluntary have the potential to influence market patterns. It is possible that a privately developed certification scheme could be subject to WTO rules if it becomes linked to government, for example if incentives are granted to certified biofuels where the certification relies on the scheme developed by a private body. ${ }^{181}$

\footnotetext{
${ }^{178}$ Jeremy Woods and Rocio Diaz-Chavez, The Environmental Certification of Biofuels International Transport Forum, Discussion paper No 2007-6, London, 2007, 12-13.

${ }^{179}$ Mol, above n 39, 72.

${ }^{180}$ Zarrilli, above n 92, pvi.

${ }^{181}$ Ibid, 32.
} 


\section{A Scope of WTO Agreements in governing biofuel certification schemes}

The WTO recognises the importance of technical regulations, standards and conformity assessment systems, and encourages their development. However, the WTO also recognises that rules must be applied to ensure that regulations conform to WTO principles and are not unnecessarily restrictive to trade.

The WTO agreement that relates to trade in goods is the General Agreement on Tariffs and Trade (GATT), ${ }^{182}$ which describes the broad trade principles. In addition to the GATT, there are extra agreements that deal with the requirements of specific issues.

The agreement that governs certification schemes is the Agreement on Technical Barriers to Trade (TBT). ${ }^{183}$ The TBT Agreement recognises that WTO Member governments have the right to set product specifications for legitimate objectives, including environmental protection; however, the measures must be non-discriminatory and must not present unnecessary obstacles to trade. ${ }^{184}$ The TBT Agreement makes a distinction between a "standard" and a "technical regulation". A technical regulation is defined as "a document which lays down product characteristics or their related processes and production methods, including the applicable administrative provisions, with which compliance is mandatory". ${ }^{185}$ Many of the biofuels certification schemes developed by national governments would meet this definition, including those of the European Union, Germany and the United Kingdom. A standard, as defined by the TBT Agreement, differs from a technical regulation in that compliance with a standard is not mandatory. Some biofuels certification schemes, for example voluntary labelling programmes designed by private companies, would fall under this definition rather than the definition of technical regulation. ${ }^{186}$ Biofuels certification is also likely to involve systems to verify that the criteria for sustainable production have been met, which could include procedures for sampling, inspection, audit, registration or approval. These systems are called “conformity assessment procedures”, which the TBT Agreement

\footnotetext{
182 General Agreement on Tariffs and Trade (15 April 1994).

183 TBT Agreement, above n 5.

184 Ibid., art 2.2.

185 Ibid, Annex 1.

${ }^{186}$ However, some voluntary labelling regulations are considered mandatory. For example, the Panel in the United States - Measures Concerning the Importation, Marketing and Sale of Tuna and Tuna Products considered that the "dolphin safe" labelling system of the United States constituted a mandatory technical regulation, although there was a dissenting opinion by one panellist. United States - Measures Concerning the Importation, Marketing and Sale of Tuna and Tuna Products (15 September 2011) WT/DS381/R, para 7.145 (Panel Report).
} 
defines as "any procedure used, directly or indirectly, to determine that relevant requirements in technical regulations or standards are fulfilled”. ${ }^{187}$

The requirements of the TBT Agreement and the GATT overlap in several areas and both contain requirements that would apply to biofuel certification schemes, with the TBT requirements being generally more specific than those of the GATT. When considering which agreements apply to certain measures, the Appellate Body has stated that the rights and obligations under the GATT and the more specific agreements (including the TBT Agreement) apply cumulatively and hold equal binding force. ${ }^{188}$ The TBT Agreement and the GATT can both be applicable to a specific measure, and Members must therefore comply with both agreements simultaneously. ${ }^{189}$ Where a dispute involves claims under both the GATT and the TBT Agreement, the claims under the TBT Agreement are usually examined first as it is the more specific agreement, but dispute panels are free to consider claims in the order they consider most appropriate. ${ }^{190}$ The requirements in the GATT and TBT Agreement that apply to biofuels certification are described and compared in this section.

Regulations imposed by an importing country must treat products originating in the territory of another WTO Member no less favourably than like products of national origin. This means that market access, taxes and other charges applied to biofuels must be done in a way that does not afford protection to the domestically produced biofuel over imported biofuel. ${ }^{191}$ This is referred to as the "National Treatment” principle, and is covered by Article III of the GATT. This article states, in the relevant part, that: ${ }^{192}$

internal taxes and other internal charges, and laws, regulations and requirements affecting the internal sale, offering for sale, purchase, transportation, distribution or use of products, and internal quantitative regulations requiring the mixture, processing or use of products in specified amounts or proportions, should not be applied to imported or domestic products so as to afford protection to domestic production.

\footnotetext{
187 TBT Agreement, above n 5, Annex 1.3

188 Gabrielle Marceau and Joel P. Trachtman "The Technical Barriers to Trade Agreement, the Sanitary and Phytosanitary Measures Agreement, and the General Agreement on Tariffs and Trade. A Map of the World Trade Organization Law of Domestic Regulation of Goods” (2002) 36(5) Journal of World Trade, 866. References the Appellate Body in EC - Bananas III and Canada Periodicals.

${ }^{189}$ Peter van den Bossche, The Law and Policy of the World Trade Organization: Text, Cases and Materials. Cambridge University Press, Cambridge, 2005, p459.

${ }^{190}$ United States - Measures concerning the importation, marketing and sale of tuna and tuna products above $\mathrm{n}$ 186, para $7.37-7.43$.

${ }^{191}$ Echols, above n 177, 3.

192 GATT, above n 182, Article III.
} 
Similarly, market access, taxes and other charges applied to imported products must not confer an advantage to one exporting country over another. This is referred to as the "Most Favoured Nation” principle (MFN) and is covered by Article I of the GATT. This article states that, in relation to customs duties and charges: ${ }^{193}$

any advantage, favour, privilege or immunity granted by any contracting party to any product originating in or destined for any other country shall be accorded immediately and unconditionally to the like product originating in or destined for the territories of all other contracting parties.

Article 2.1 of the TBT Agreement aligns with Articles I and III of GATT, requiring treatment no less favourable than that accorded to like products of national origin and to like products originating in any other country. It states that: ${ }^{194}$

Members shall ensure that in respect of technical regulations, products imported from the territory of any Member shall be accorded treatment no less favourable than that accorded to like products of national origin and to like products originating in any other country.

As the scope and meaning of Article 2.1 is similar to that of Articles I and III of the GATT, it is likely that a technical regulation that is inconsistent with Article 2.1 will also be found to be inconsistent with either Article I or III. ${ }^{195}$

There may be exceptions where discrimination is allowed. If a measure is inconsistent with Article I or III of the GATT, the violation may be justified under Article XX of the GATT. Article XX states that: ${ }^{196}$

Subject to the requirement that such measures are not applied in a manner which would constitute a means of arbitrary or unjustifiable discrimination between countries where the same conditions prevail, or a disguised restriction on international trade, nothing in this Agreement shall be construed to prevent the adoption or enforcement by any contracting party of measures:

... (b) necessary to protect human, animal or plant life or health;

\footnotetext{
193 GATT above n 182, Article 1.

194 TBT Agreement, above n 5, Article 2.1.

${ }^{195}$ Marceau, above n 188.

${ }^{196}$ GATT, above n 182, Article XX.
} 
... (g) relating to the conservation of exhaustible natural resources if such measures are made effective in conjunction with restrictions on domestic production or consumption...”

If a measure is inconsistent with Article 2.1 of the TBT Agreement, there is no list of general exceptions in the TBT Agreement under which the violation could be justified. While technical regulations by their nature are likely to be restrictive to trade, the TBT Agreement states that they cannot be any more trade restrictive than necessary to fulfil a "legitimate objective”. A list of legitimate objectives is contained in Article 2.2, which states that: ${ }^{197}$

Members shall ensure that technical regulations are not prepared, adopted or applied with a view to or with the effect of creating unnecessary obstacles to international trade. For this purpose, technical regulations shall not be more trade-restrictive than necessary to fulfil a legitimate objective, taking account of the risks non-fulfilment would create. Such legitimate objectives are, inter alia: national security requirements; the prevention of deceptive practices; protection of human health or safety, animal or plant life or health, or the environment. In assessing such risks, relevant elements of consideration are, inter alia: available scientific and technical information, related processing technology or intended end-uses of products.

Although the wording of Article 2.2 of the TBT Agreement and Article XX of the GATT is similar, an important difference is that Article 2.2 cannot be used as a defence. A technical regulation must comply with both Articles 2.1 and 2.2 of the TBT Agreement. An issue of debate is whether Article XX of the GATT can be used to justify a violation of Article 2.1 of the TBT Agreement. Although the list of exceptions in GATT Article XX is broader, it is also considered to be a closed list, whereas the list of legitimate objectives provided in TBT Article 2.2 is an open list. It is therefore possible that a technical regulation could be inconsistent with the GATT if it cannot be justified under any of the sub-paragraphs of Article XX, but at the same time it could be considered "necessary" to fulfil a legitimate objective under Article 2.2 of the TBT Agreement. ${ }^{198}$

Marceau and Trachtman ${ }^{199}$ argue that, due to the differing scope of Articles XX and 2.2, and the fact that they are contained in different agreements, it is doubtful that Article XX

\footnotetext{
197 TBT Agreement, above n 5, Article 2.2

198 Marceau, above n 188, 875.

199 Ibid., 823.
} 
would be available as a defence to a violation of the TBT Agreement. This raises a concern that a technical regulation could be inconsistent with Article III, but justified under Article XX of the GATT. That same regulation would also be inconsistent with Article 2.1 of the TBT Agreement, but cannot be justified under either agreement, ${ }^{200}$ resulting in contrasting findings for a similar analysis under the two Agreements. Condon ${ }^{201}$ supports the view that Article $\mathrm{XX}$ is unlikely to justify a violation of the TBT Agreement, given that the TBT Agreement incorporates specific language regarding "legitimate objectives" rather than incorporating the language of Article XX of the GATT.

The alternative argument is that, given that the GATT and TBT Agreement are cumulative and apply simultaneously, Article XX could be used to justify a violation of an article under the TBT Agreement. ${ }^{202}$ This argument is supported by the statement in the TBT Agreement preamble that it is intended to further the objectives of the GATT. The Appellate Body has stated the view that the relationship between the GATT and other agreements must be considered on a case-by-case basis. ${ }^{203}$ In cases that have involved claims under the GATT and the TBT Agreement (EC - Asbestos and US - Gasoline) the Appellate Body has examined claims under the GATT and not the TBT Agreement, despite the applicability of the TBT Agreement to the measures in question. ${ }^{204}$ This is also the case for appeals involving the GATT and the Antidumping Agreement (US-Shrimp (Thailand) and US - Customs Bond Directive). ${ }^{205}$

The points raised above highlight that, if a biofuels certification scheme were found to be compliant with the GATT, it would not necessarily be compliant with the TBT Agreement or vice versa. The following sections therefore examine the compliance of certification schemes with both Agreements. Article XX is included in the analysis for its role in providing a defence for measures inconsistent with other articles of GATT, and in recognition that it could possibly - but not necessarily - be available as a defence for a measure that is inconsistent with the TBT Agreement.

\footnotetext{
200 Ibid., 874.

${ }^{201}$ Bradly Condon, “Climate change and unresolved issues in WTO law” (2009) 12 J. Int'l Econ. L., 925-26.

${ }^{202}$ Marceau, above n 188, 874.

203 Condon, above n 201, 905-6; Brazil - Measures Affecting Desiccated Coconut (21 February 1997) WT/DS22/AB/R, para 13 (Appellate Body, WTO).

${ }^{204}$ European Communities - Measures Affecting Asbestos and Asbestos-Containing Products (12 March 2001) WT/DS135/AB/R, para 80-83 (Appellate Body, WTO). United States - Standards for Reformulated and Conventional Gasoline (29 January 1996). WT/DS2/AB/R, I.C.8 and II.C (Appellate Body, WTO).

${ }^{205}$ Condon, above n 201, 903.
} 


\section{B Consistency of biofuel certification with WTO Agreements}

Certification of biofuels on the basis of sustainability is a complex legal issue, particularly when the criteria for certification are wide-ranging and difficult to quantify (as is the case for assessing labour rights, rural development and food security). Analysis of the WTOconsistency of biofuels certification highlights two areas that could be problematic. These two areas relate to:

- Article 2.1 of the TBT Agreement and Articles I and III of the GATT; and

- Article 2.2 of the TBT Agreement and Article XX of the GATT.

Article 2.1 of the TBT Agreement and Articles I and III of the GATT place obligations on Members to ensure that imported products are accorded treatment no less favourable than that accorded to like products of national origin and to like products originating in any other country. This raises the question of whether biofuels that are certified as sustainably produced are considered to be "like" biofuels that are not certified. If they are determined to be "like" products, then incentives to certify, such as favourable taxes or tariffs, could be considered to apply favourable treatment to sustainably produced biofuels. As the end product characteristics of certified and uncertified biofuels would be the same (taking into account the different types of biofuel, i.e. bioethanol and biodiesel), the two products could only be considered "unlike" if the method of production is taken into account. There is considerable debate about whether production methods can be taken into account when determining the "likeness" of two products; if biofuels cannot be certified based on manufacturing processes, then all will be considered to be "like" goods. If this is the case, then governments aiming to promote sustainable biofuel use will not be able to apply tax or tariff concessions to biofuels produced in a manner that reduces greenhouse gas emissions. Since the link between certification and tax breaks may become increasingly important for meeting national or regional blending targets and renewable energy use obligations, the WTO determination of product "likeness" based on method of manufacture requires further attention, and is discussed in detail in the following section. ${ }^{206}$

Article 2.2 of the TBT Agreement states that technical regulations must not create unnecessary obstacles to international trade. For this purpose, technical regulations shall not be more trade-restrictive than necessary to fulfil a legitimate objective, such as protection of

206 United Nations Conference on Trade and Development, Making Certification Work for Sustainable Development: The Case of Biofuels, United Nations, New York and Geneva, 2008, 31 
human health or safety, animal or plant life or health, or the environment. The questions raised by Article 2.2 are whether biofuels certification is fulfilling a legitimate objective and, if so, whether certification could be more trade-restrictive than necessary to fulfil this objective. The objective of a biofuels certification scheme is likely to be presented as the protection of human health or safety, animal or plant life or health, or the environment. Although Members clearly have the right to impose trade measures to protect the environment within their own borders, it is not clear if they can impose measures with the purpose of protecting the environment in another country, or on a global scale. A similar question is whether measures that are inconsistent with other Articles of the GATT or TBT Agreement could be justified by Article XX of the GATT, if the purpose of the measure is the protection of the environment outside of national boundaries. This issue is discussed in detail in section B.2.

\section{Certification based on method of production}

Technical regulations and standards set out the specific characteristics of a product in a way that distinguishes between products and provides the consumer with information about the characteristics of the product. Sometimes, it is more appropriate to set the regulations and standards in terms of a product's manufacturing process and production methods, rather than its characteristics. This is the case with biofuel certification - products would be categorised based on the impact that their production has on the environment or on social conditions (i.e. produced in a sustainable manner or not), rather than on the characteristics of the endproduct. Some of the certification schemes developed by governments limit the feedstocks that can be used for biofuel production. For example, biofuels produced from palm oil, soya and grain do not qualify for tax exemption in Switzerland, despite the end product (biodiesel) being the same as that produced from qualifying feedstocks. ${ }^{207}$

Discrimination on the basis of non-product-related production methods is contentious, and there is a preconception that this type of distinction is protectionist, and could undermine the principle of non-discrimination according to which like products are to receive equal treatment. ${ }^{208}$ For example, if a technical regulation prescribes the way in which a product should be manufactured, this limits the freedom of the producers to manufacture according

\footnotetext{
${ }^{207}$ Echols, above n 177, 6.

${ }^{208}$ Ibid, 6; WTO Committee on Trade and Environment, Report of the Meeting Held on 10 July 2009 (World Trade Oganization WT/CTE/M/47 31 August 2009); WTO Committee on Trade and Environment, CTE Report of the Meeting Held on 3 November 2008 (World Trade Oganization WT/CTE/M/46 12 January 2009).
} 
local conditions and to the technology available to them. This could particularly limit the ability of developing countries to participate in international trade. There have been several WTO trade disputes that relate to discrimination based on production methods, and doubts exist that this form of differentiation will be well received. ${ }^{209}$

Members have questioned whether the TBT Agreement allows technical regulations to be based on process or production methods (PPMs). The text of the TBT agreement recommends that - where possible - regulations and standards should be set in terms of the performance of a product, rather than design or descriptive characteristics, as this will help avoid unnecessary obstacles to trade. ${ }^{210}$ However, in Annex 1.1 of the TBT Agreement the definition of technical regulation includes "product characteristics or their related processes and production methods..." and "may also include or deal exclusively with terminology, symbols, packaging, marking or labelling requirements as they apply to a product, process or production method"211. It would appear from this definition that the TBT agreement permits technical regulations to be based on PPMs. The definition of technical regulation might not be met if the only characteristic that the regulation lays down is not "related" to the product itself. The definition would suggest that the TBT Agreement does not apply to non-productrelated PPMs (i.e. those that do not leave any trace in the final product itself). However, the explanatory note states that "this agreement deals only with technical regulations, standards and conformity assessment procedures related to products, or processes and production methods" 212 - leaving out the word "related”. If non-product-related production methods were not covered by the TBT Agreement, then the other requirements of the TBT Agreement cannot apply to them. ${ }^{213}$ Given that the concern about PPMs regards the principle of nondiscrimination, it would be logical for all PPMs to be governed by the requirements of the TBT Agreement, not just those that are directly related to the product. The following section proceeds on the basis that non-product related PPMs are covered by the TBT Agreement.

An additional question is whether non-product-related PPMs can be taken into account when determining whether two products are "like", for the purpose of applying taxes

\footnotetext{
209 Zarrilli, above n 92, pvi and 31. WTO disputes include European Communities - Measures Affecting Asbestos and Asbestos-Containing Products, above n 204; Spain - Tariff Treatment of Unroasted Coffee (11 June 1981). L/5135 - 28S/102 (Panel Report); Japan - Taxes on Alcoholic Beverages (4 October 1996) WT/DS8/AB/R (Appellate Body, WTO).

${ }^{210}$ TBT Agreement, above n 5, Article 2.8 and Annex 3.

${ }^{211}$ Ibid., Annex 1.1

212 Ibid., Annex 1.2

${ }^{213}$ Condon, above n 201, 922.
} 
or incentives linked to the technical regulation. For example, if ethanol produced from sugarcane were accorded a different tariff from ethanol produced from corn. In this situation, the technical regulation must conform to the MFN principle by not according less favourable treatment to "like" products; differently-produced biofuels would need to be demonstrated to be not alike. The WTO definition of "like" products does not explicitly allow products to be differentiated based on their process or production methods. A more in depth analysis is required to determine if biofuels certified as sustainably produced would be "like" those that are not certified.

The GATT and TBT Agreement provide little guidance for assessing whether two products are "like". The concept of "like products" has not been defined in the GATT, nor described authoritatively by Members. Its meaning can best be interpreted through the findings of dispute panels and the Appellate Body.

The Appellate Body has developed a method of assessing likeness that involves examining four factors described in the GATT document Border Tax Adjustment. ${ }^{214}$ The approach outlined in the Report uses four general criteria in analyzing "likeness". These are: ${ }^{215}$

(i) the properties, nature and quality of the products;

(ii) the end-uses of the products;

(iii) consumers' tastes and habits in respect of the products; and

(iv) the tariff classification of the products.

The Appellate Body report on Japan - Taxes on Alcoholic Beverages further clarified the use of the four criteria, stating that: ${ }^{216}$

In applying the criteria cited in Border Tax Adjustments to the facts of any particular case, and in considering other criteria that may also be relevant in certain cases, panels can only apply their best judgement in determining whether in fact products are "like". This will always involve an unavoidable element of individual, discretionary judgement.

\footnotetext{
${ }^{214}$ GATT Report of the Working Party Border Tax Adjustment (2 December 1970) BISD 18S/97

${ }^{215}$ The final criteria was later added as a supplementary consideration; Zarrilli, above n 92, 33-35.

${ }^{216}$ Japan - Taxes on Alcoholic Beverages, above n 209, para H.1.a.
} 
The report continues to say that no one approach will be appropriate for all cases, and compares the concept of "likeness" to an accordion which stretches and squeezes according to the particular provision in which the term "like" is encountered as well as the context and circumstances of the case. The Appellate Body in EC - Asbestos also emphasised that the GATT Working Party Report on Border Tax Adjustments is not an all encompassing account of likeness, and certain criteria may be emphasised over others when analysing likeness for a given case. The four criteria should be examined both individually, and collectively as they are interrelated - for example, the physical properties of a product influence its possible end uses. $^{217}$

The development of methods for assessing the likeness of products does not provide guidance as to how different processes or production methods could be taken into account. The WTO website states that "when comparing two products, different processes or production methods used in the manufacture of such products do not per se render these products unlike". ${ }^{218}$ The website goes on to give the example of differentiating between wood products derived from sustainably grown forest, and where the production method of the wood is unknown. In this example, the determination of likeness may be "particularly challenging", and for this reason the analysis of likeness between two products should be carried out on a case-by-case basis. The section below analyses whether sustainably-produced biofuels would be considered "like" to those not sustainably produced, based on the four factors outlined by the GATT Working Party Report on Border Tax Adjustments.

\section{(a) Physical characteristics}

The first criterion outlined in the Working Party Report on Border Tax Adjustments is the product characteristics; or more specifically the "properties, nature and quality of the products”. The Appellate Body in EU - Asbestos, concerning a technical regulation, clarified that product characteristics includes any definable feature, quality attribute or distinguishing mark. ${ }^{219}$ Such characteristics could include product composition, size, colour, texture, flammability, conductivity and so on. For biofuels, the obvious physical qualities and characteristics would be the chemical composition, appearance, texture and smell. There would be a clear difference between biodiesel and bioethanol, and individual products may

\footnotetext{
${ }^{217}$ European Communities - Measures Affecting Asbestos and Asbestos-Containing Products, above n 204, para 102.

${ }^{218}$ World Trade Organization http://www.wto.org/english/tratop_e/envir_e/envt_rules_gatt_e.htm (Accessed 26 April 2010).

${ }^{219}$ EC - Asbestos, above n 204, para 67.
} 
have different characteristics due to a different chemical composition. However, the sustainability - or otherwise - of feedstock production, in itself, is unlikely to produce any obvious and consistent differences in the physical characteristics of each type of biofuel.

One possible approach would be to argue that the carbon footprint of a biofuel could be a distinguishing characteristic, if biofuels are labelled by their carbon footprint or greenhouse gas savings. ${ }^{220}$ One of the criteria used in certification schemes is the amount of greenhouse gas emissions saved by using a certain biofuel rather than fossil fuel, with only biofuels below a certain level of greenhouse gas emissions, calculated on a life-cycle basis, qualifying for tax exemptions or quotas. The problem with this approach is that the carbon footprint is not a part of the product itself, but rather a characteristic of the production process. If the likeness of product characteristics depends on the products themselves, then this approach would not be acceptable in differentiating between biofuels based on their sustainability.

In the EC - Asbestos dispute, the complainant, Canada, argued that asbestos and products containing asbestos were "like" the alternative fibres and products that would replace the asbestos. As the alternative fibres were manufactured in France, Canada argued that the EC ban on asbestos was incompatible with Article 2.1 of the TBT Agreement and Article III:4 of the GATT which state that imported products should not be treated less favourably than like products of national origin. Part of Canada's argument for likeness between asbestos and the alternative fibres and products was that the manufacturing processes were very similar. ${ }^{221}$ Although the Panel found that the products were "like", this was on the basis of their properties and end-uses, not on their method of manufacture, implying that method of manufacture should not be taken into account in the analysis. ${ }^{222}$

Interestingly, the EC argued that asbestos and its alternative products should not be considered to be "like" on the basis that asbestos poses a significant risk to human health, and that this is an aspect of the "quality" of a product. ${ }^{223}$ In its report, the Panel noted that the risk of a product for human or animal health has never been used as a factor in determining likeness within the meaning of Article III. Article XX of the GATT, however, authorises measures aimed at preserving these interests. The Panel determined that it was not

\footnotetext{
${ }^{220}$ Condon, above n 201, 910.

${ }^{221}$ European Communities - Measures Affecting Asbestos and Asbestos-Containing Products (18 September 2000) WT/DS135/R, para 8.129 (Panel Report).

${ }^{222}$ Ibid, paras 8.126 and 8.136. Note that the Appellate Body reversed the Panel finding that the products were "like".

${ }^{223}$ Ibid, para 3.431.
} 
appropriate to include risk in the analysis of likeness within the meaning of Article III, as this would largely nullify the effect of Article XX(b). ${ }^{224}$ However, the Appellate Body overruled this decision, stating that: ${ }^{225}$

in examining the "likeness" of products, panels must evaluate all of the relevant evidence. We are very much of the view that evidence relating to the health risks associated with a product may be pertinent in an examination of "likeness" under Article III:4 of the GATT 1994.

Furthermore, this would not nullify Article $\mathrm{XX}(\mathrm{b})$ of the GATT as the two articles are independent provisions, each to be interpreted on its own.

In a similar way, biofuels that are not produced in a sustainable manner could be posing a risk to the environment, to social conditions and to food security. This risk could be described as an aspect of the "quality" of the biofuel and be used as a way to distinguish between two otherwise "like" biofuels. The difference between biofuels and the asbestos case described is in demonstrating that the measure is necessary. The argument is easier for the asbestos measures, which were necessary to meet the goals of a domestic human health policy. The argument of whether biofuels certification is necessary to meet policy objectives of protecting global resources is a more complex issue and is discussed further in section 2.B.

\section{(b) End uses}

The Appellate Body has stated that an analysis of whether the end uses of two products overlap must be based on the complete picture of all possible end uses for the products in question. ${ }^{226}$ If the products overlap in only a small number of possible end uses, then the Appellate Body would consider the importance of the overlapping end uses in competitiveness of the products. ${ }^{227}$

The fact that two products have the same end use is likely to undermine any argument that they are not "like" due to differing methods of production. For example, in the Spain Tariff Treatment of Unroasted Coffee dispute, Brazil claimed that a new Spanish law to apply different tariff rates to unroasted or "unwashed" coffee (in contrast to "mild" coffee) was in violation of Article I:1 of the GATT (1947). Spain argued that mild and unwashed coffee

\footnotetext{
${ }^{224}$ Ibid, para 8.130, 8.131, 8.132.

${ }^{225}$ EC - Asbestos, above n 204, para 113.

${ }^{226}$ Ibid., para 106.

${ }^{227}$ Ibid, para 143.
} 
were not "like" products due to different cultivation and preparation methods, and therefore the differential tariff rate was not inconsistent with Article I:1. ${ }^{228}$ The Panel found that agricultural products would often differ in taste due to their cultivation methods, and this was not sufficient reason to allow for differential tariff rates. The Panel also pointed out that coffee in its end-use was universally regarded as a well-defined and single product intended for drinking; with different types of coffee being blended, the two types of beans were not available as distinct products. Therefore mild and unwashed coffee beans should be considered to be "like" products under the meaning of Article I:1. 229

There are similarities between the Spain - Tariff Treatment of Unroasted Coffee dispute and the Japan - Tariff on Imports of Spruce, Pine, Fir (SPF) Dimension Lumber dispute. Like the coffee dispute, the SPF Lumber dispute involved a differential tariff, applied by Japan, on dimension lumber from different coniferous species, all of which had the same end use. Canada complained that this constituted discrimination between "like products", in contravention of obligations under Article I of the GATT. However, in this case the Panel declined to rule on the "likeness" of the products, as the concept of "dimension lumber" was not sufficient to separate the lumber in question from planed lumber generally. As Canada did not contend that different lumber species should be considered like products, regardless of the end form of the product, the Panel stated that there was no basis for examining the issue raised in the context of the Japanese tariff classification. ${ }^{230}$

The end uses of sustainably produced biofuel are likely to be identical or mostly overlapping with biofuel that is not sustainably produced. In fact, one of the main reasons for national government to promote the use of biofuel is for blending with conventional fuel for use in transport. In order to meet the policy goal, biofuel needs to be similar enough to other fuels (including other biofuels) to allow the fuels to be mixed for the same end use. The regulation of biofuels may result in certified and uncertified biofuels having different end uses, if only certified biofuels can be used for some purposes, such as fuel for government fleets. If the consistency of the regulation with WTO trade agreements is being disputed, the

\footnotetext{
${ }^{228}$ Spain - Tariff Treatment of Unroasted Coffee, above n 209, para 3.7.

229 Ibid, paras 4.6, 4.7, 4.9.

${ }^{230}$ Japan - Tariff on Imports of Spruce, Pine, Fir (SPF) Dimension Lumber (19 July 1989). L/6470 - 36S/167, para 5.14 (Panel report).
} 
regulation could not be justified based on a difference between products that is a result of the regulatory distinction that is at the core of the dispute. ${ }^{231}$

\section{(c) Consumer habits}

It is possible to show that two, otherwise similar, products are not "like" due to differences in consumer preference. There is growing environmental awareness among consumers, and it is plausible that a consumer will want to know the origin of the goods being purchased and the effect that they have on the environment. This method for determining likeness was an important factor in the EC-Asbestos case described above. In this ruling, the Appellate Body found that the health risk associated with the product would affect consumer's tastes and habits (in addition to the differences in product characteristics), and would be likely to influence the competitive relationship between products in the marketplace. ${ }^{232}$ This ruling implies that other non-trade concerns, such as environmental protection, could be used in assessing "likeness” based on consumer habits. ${ }^{233}$

Consumers for biofuels include individuals (purchasing fuels at the pump) or a retailer (purchasing biofuels for blending and on-selling to individuals). Due to the blending of biofuels, individual consumers may not be aware of the source of the fuels being purchased even if the fuel is labelled as a biofuel blend, the consumer will not know if the biofuel is certified as sustainably produced unless the retailer markets the fuel as such. A retailer is more likely to know the source of the biofuel, and whether or not it is certified as sustainable; but the retailer is also likely to be influenced by other factors such as the cost and the physical properties. ${ }^{234}$ Also, if there is a blending requirement in place, it would be impossible to distinguish between the two possible motives for the retailer to purchase certified biofuel: the need to meet a quota and the concern of the environmental impact of biofuel production. The use of select methodology for determining sustainability may also distort consumer perception of what is acceptable. Where consumer opinion is based on questionable methodology, the consumer habits should not be used as a way to determine the likeness of two products. ${ }^{235}$ Market studies and other evidence would be needed in order to determine

\footnotetext{
231 This was the logic followed by the panel in the United States - Measures Concerning the Importation, Marketing and Sale of Tuna and Tuna Products dispute in relation to consumer preferences, above n 186, para 7.247.

${ }^{232}$ EC - Asbestos, above n 204, para 117.

233 Zarrilli, above n 92, 33-35.

${ }^{234}$ Woods, above n 178.

235 Switzer, above n 124, 16.
} 
the effect of consumer preference on the product differentiation and the competitive relationship between certified and uncertified biofuel.

\section{(d) Customs classification}

Customs classification under the Harmonized System is the fourth factor that has been considered by the Appellate Body in determining likeness of products. In Japan - Taxes on Alcoholic Beverages, the Appellate Body reported: ${ }^{236}$

Uniform classification in tariff nomenclatures based on the Harmonized System (the "HS") was recognized in GATT 1947 practice as providing a useful basis for confirming "likeness" in products. However, there is a major difference between tariff classification nomenclature and tariff bindings or concessions made by Members of the WTO under Article II of the GATT 1994. There are risks in using tariff bindings that are too broad as a measure of product "likeness".

The HS works by grouping products into categories, as it is not possible to have a classification for each different product. The categories can be broad, but Members are able to further define the product categories as needed (so long as the tariffs applied to subcategories do not exceed the tariff applied to the general HS category, and so long as the MFN obligation is not violated). As noted by the Appellate Body, problems arise with using tariff classification as a method of determining likeness when the HS is not sufficiently detailed, and this method would be more useful to support a decision regarding likeness, rather than used as the determining factor. ${ }^{237}$

The categorisation of biofuels under the HS is complicated; ethanol is classified under the Harmonized System as an agricultural good (HS 220720 for denatured ethanol and HS 220710 for undenatured ethanol), and biodiesel as an industrial good (HS 3824 90). Therefore, tariffs and subsidies for the two types of biofuels are governed by different WTO rules, and furthermore ethanol is on an uneven keel with fossil fuels, which is classified as an industrial good. ${ }^{238}$ Additionally, feedstocks for biofuels are classified differently to the biofuel end product. Although the different tariff classifications is likely to support any decision that different types of biofuels are not "like" products, the tariff classification is not aligned with whether or not biofuels are sustainably produced. A reclassification of biofuels

\footnotetext{
${ }^{236}$ Japan - Taxes on Alcoholic Beverages, above n 209, H.1.a.

${ }^{237}$ Condon, above n 201, 908; Japan - Taxes on Alcoholic Beverages, above n 209, 25.

${ }^{238}$ Motaal, above n 41, 77-78
} 
under the HS has been deemed appropriate by some experts, who also acknowledge that this would be a lengthy process. $^{239}$ However, even if the HS is revised to provide more consistency between the different types of biofuels, the HS is still unlikely to support a claim that certified and uncertified biofuels are not like products, unless sustainability is taken into account in the classification (as discussed further below).

The messy tariff classification of biofuels raises other trade concerns. Product classification is important in the negotiation of tariffs, subsidies and other domestic policies that affect trade. The classifications for biofuels are not necessarily aligned to their use, which undermines consistency, transparency and equality in the application of tariffs and subsidies, and could influence a determination of likeness. For example, in the Spain - Tariff Treatment of Unroasted Coffee dispute, the panel - in finding that different types of coffee were "like products" - took into consideration the fact that no Member had introduced subclassifications for the types of coffee in question. ${ }^{240}$ The panel in Japan - SPF Lumber also considered tariff classification, noting that the concept of “dimension lumber" did not belong to any internationally accepted customs classification. They therefore declined to consider if dimension lumber from different species were "like" products. ${ }^{241}$

There is also a debate as to whether biofuels should be classified as an "environmental good”. Several Members, including Brazil, India, Canada and New Zealand have suggested that biofuels be included on a list of "environmental goods" for accelerated trade liberalisation under the current Doha Round of negotiations. ${ }^{242}$ The aim of this classification is to achieve a greater tariff reduction than average for goods that have a potential to achieve environmental goals; however so far there has been little progress on developing the definition of an "environmental good". Although biofuels have many positive attributes which could qualify them as environmental goods, there is still significant debate about whether biofuels have an overall positive environmental benefit, and the risks associated with their production would need to be taken into consideration. ${ }^{243}$ If internationally-agreed criteria were developed for certifying the sustainable production of biofuels, this would be likely to assist in discussions on their classification as environmental goods. Additionally, if biofuels were classified as environmental goods, on the condition of their sustainability

\footnotetext{
${ }^{239}$ For discussion see Motaal, above n 41 and Howse, anove n 24.

${ }^{240}$ Spain - Tariff Treatment of Unroasted Coffee, above n 209, para 3.11.

241 Japan - SPF Lumber, above n 230, para 5.14 to 5.16.

${ }^{242}$ Motaal, above n 41, 80.

${ }^{243}$ Howse, above n 24, 12
} 
certification, this would also support any argument that the sustainability criteria are a legitimate point of differentiation between the biofuel products. The Doha Round has had particularly slow progress in the 10 years since its initiation, and progress has stalled for many of the negotiations. As with other trade issues, the lack of progress may mean that resolution on environmental goods will not be reached in the Doha Round.

\section{(e) Other relevant disputes}

The Appellate Body has stated that other factors than the four outlined in the Border Tax Adjustment Report, could be used to determine the likeness of products. There have been a few dispute cases which are well known for raising the issue of whether production methods may be used to distinguish between products, but which have not relied on the approach described in the Border Tax Adjustment Report.

The US - Restrictions on Imports of Tuna (Mexico) dispute involved a complaint by Mexico on the US standards imposed on imported tuna, which were based on the method by which the tuna was caught (methods which afforded protection to dolphins versus methods which did not). The Panel found that the method of harvesting tuna could not affect tuna as a product. Therefore the Panel directed the US to accord treatment to imported tuna no less favourable than that accorded to US tuna, regardless of whether the dolphin-protection methods used by Mexican vessels corresponds to that of US vessels. ${ }^{244}$ The Panel report was not adopted by the GATT, and therefore has no normative value, but nonetheless provides useful reasoning on the use of production methods to determine product "likeness". 245

The US - Import Prohibition of Certain Shrimp and Shrimp Products was a similar dispute involving a US requirement for imported shrimp to be harvested using a device that reduced the incidental killing of sea turtles. The complainants (India, Pakistan and Thailand) argued that the requirement was inconsistent with the MFN principle because physically identical shrimp imported from different nations were accorded different treatment by the US, based solely on the method of harvest. ${ }^{246}$ In this case the Panel did not complete an analysis of "likeness". The US regulation was found to be inconsistent with GATT Article XI, therefore the Panel did not examine the complaints raised in the context of GATT

\footnotetext{
${ }^{244}$ United States - Restrictions on Imports of Tuna (DS21/R - 39S/155, para 5.15 (Panel Report).

245 Japan - Taxes on Alcoholic Beverages, above n 209, 14-15.

${ }^{246}$ US - Import Prohibition of Certain Shrimp and Shrimp Products (15 May 1998) WT/DS58/R, section 3 (Panel Report).
} 
Articles I or III. ${ }^{247}$ Additionally, the Appellate Body found the US measure to be justified under Article XX(g); the implications of this finding for biofuel certification are discussed in section 2.

\section{(f) Discussion and summary}

There is little clear guidance on whether uncertified biofuels and biofuels certified as sustainably produced would be considered “like” products. If a biofuels certification scheme were challenged as being inconsistent with the TBT Agreement Article 2.1 and GATT Articles I and III, the history of dispute findings would suggest that the differentiation of biofuels based on the sustainability of their production would not be an acceptable defence. None of the four factors used by the Appellate Body to determine likeness could be relied on for demonstrating that certified and uncertified biofuels are not "like" products. The argument that certified and uncertified biofuels differ in their risk to the environment could provide an avenue, as a similar defence was successful in the EC-Asbestos dispute. However this raises the question of whether environmental risk is a factor that is better addressed under Article XX of the GATT which provides for Members to impose conditions with the purpose of protecting the environment.

If sustainably produced biofuels and non-sustainably produced biofuels are considered to be "like" products, regulatory distinctions could still be drawn between them based on production method. However, the measures imposed as a result of this distinction must not disadvantage imported products over domestic products, or imported products from one country over another. For example, the panel in the European Communities - Measures Affecting the Approval and Marketing of Biotech Products dispute found that, regardless of the likeness of GMO and non-GMO products, the EC could still make regulatory distinctions between the two as the regulations did not result in less favourable treatment of imported products. $^{248}$

The more advanced biofuels certification initiatives developed by governments, including the European RED, the German sustainability ordinance and the Swiss Mineral Oil Taxation Law have stated that the sustainability criteria will apply equally to both imported and domestically produced biofuels. Similarly, both imported and domestically produced biofuels will qualify for the same benefits. Nonetheless, consideration needs to be given to the ability

\footnotetext{
${ }^{247}$ Ibid, section 7.

${ }^{248}$ European Communities - Measures Affecting the Approval and Marketing of Biotech Products (29 September 2006) WT/DS291/R, para 7.2505 (Panel Report).
} 
of exporting countries to meet the criteria of sustainability schemes, and the cost of doing so. It is possible that a sustainability scheme could, either intentionally or inadvertently, burden certain exporting countries more than others, resulting in discrimination in favour of domestic production or in favour of imports from particular Members. ${ }^{249}$ The highly prescriptive nature of some of the standards and the lack of consistency between them could make their application to local conditions difficult, limiting the ability of some countries to meet such standards. The metastandard approach, such as is used in the UK RTFO, would minimise the effect of local conditions on the ability to meet certification requirements.

As an example, certification may be more difficult to achieve for producers of certain feedstocks. A clear instance of this is the Swiss Mineral Taxation Law, which excludes biofuels produced from palm oil, soybeans and cereals from qualifying for the tax exemption. This could be interpreted as discriminatory against Members such as Malaysia and Indonesia which produce biofuels predominantly from palm oil, and are looking to expand the industry. ${ }^{250}$ A less clear example is the regulation, set out in the European RED and the UK RTFO, which grants certification based on the greenhouse gas savings achieved for different biofuels. These schemes set "default factors" for greenhouse gas savings for types of feedstocks, countries and processes, which are used when insufficient information is supplied to determine greenhouse gas savings for a particular supplier. The default factor is more favourable to some feedstocks than others, for example the default value for biodiesel produced from rapeseed is 38 per cent, which is more favourable than the default value for biodiesel produced from palm oil which is only 19 per cent. ${ }^{251}$ Noting that the RED criterion is the achievement of 35 per cent greenhouse gas savings, producers of biodiesel from palm oil would need to provide additional detailed information about the production of their biofuels in order to receive the certification and associated benefits, where as producers of biodiesel from rapeseed would not. Another factor to consider is that European biodiesel is predominantly produced from rapeseed, sunflower seed and soybean, but not from palm oil.

The requirement to meet a criterion on greenhouse gas emission savings could discriminate based on the foreign origin of biofuel depending on the method of calculation. For example, if greenhouse gas emissions were calculated based on the entire life cycle of the biofuel, this would include the greenhouse gases produced during the transportation of biofuels or their feedstocks from the production location to the location in which they are

\footnotetext{
${ }^{249}$ Howse, above n 24, 24-25.

${ }^{250}$ Steenblick, above n 155, 36.

251 Switzer, above n 124, 16.
} 
sold and consumed - this factor could be particularly significant for imported bioethanol which requires specific transportation methods. The further the biofuels would have to travel, the lower the resulting greenhouse gas emission savings. The requirement for certification would therefore be more trade restrictive for biofuels imported from distant locations than for biofuels produced domestically. The impact that this would have on the competitive relationship between imported and domestic biofuels would need to be examined in more detail before drawing firm conclusions on less favourable treatment.

In summary, Article 2.1 of the TBT prohibits members from favouring domestic over imported "like" goods, or favouring imported products from one country over another. There are regulations contained in some certification schemes which could be interpreted as according imported biofuels less favourable treatment to domestically produced biofuels. If certified and uncertified biofuels are considered to be "like" products, an importing country's application of a sustainability standard for biofuels could violate the non-discrimination provisions of the GATT and/or the TBT Agreement.

There are some situations in which violation of non-discrimination provisions are accepted. For example, exceptions may be granted to regulations that are designed to fulfil certain objectives, including the protection of human health and safety and the protection of the environment. However, these exceptions must not be applied in an arbitrary or discriminatory manner, and must be necessary to fulfil the objective. ${ }^{252}$ The following section discusses if biofuels certification schemes could be justified under these provisions.

\section{$2 \quad$ Trade and environmental protection}

The WTO recognises as one of its goals the protection and preservation of the environment. ${ }^{253}$ A "Decision on Trade and Environment" was signed which stated that there should not be any contradiction between upholding the multilateral trading system, protecting the environment, and promoting sustainable development. The decision also called for the creation of the Committee on Trade and Environment. ${ }^{254}$

The Trade and Environment Committee was established following the Uruguay Round of negotiations in 1994. The Committee looks into circumstances where

\footnotetext{
${ }^{252}$ GATT above n 182, Article XX.

253 Marrakesh Protocol to the General Agreement on Tariffs and Trade 1994 (15 April 1994).

254 Decision on Trade and Environment. Adopted by ministers at the meeting of the Uruguay Round Table Negotiations Committee in Marrakesh, 14 April 1994.
} 
environmental agreements have an impact on trade. However the WTO does not set international standards and clearly states that it is not an environmental organisation, ${ }^{255}$ and the Committee states that the best way to deal with international environmental problems is through environmental agreements. The WTO encourages the use of international standards where they exist, and when countries use an international standard they are less likely to be challenged legally in a WTO dispute. Where a dispute arises it should be settled through provisions of the international environmental agreement, if all parties are signatories. In the event that a dispute cannot be resolved through the agreement in question, the WTO could provide a platform for Members to complain and request adjustments. As there is currently no international environmental agreement specifically addressing the sustainability of biofuels, any conflict arising between Members would be resolved through the WTO dispute settlement process. ${ }^{256}$

Although the WTO has no specific agreement for environmental protection, it permits governments to restrict trade when necessary to protect the environment. Two Articles relate to environmental and human health protection.

Article XX of the GATT allows members to justify measures if these are either necessary to protect human, animal or plant life or health $(\mathrm{XX}(\mathrm{b}))$, or if the measures relate to the conservation of exhaustible natural resources $(\mathrm{XX}(\mathrm{g}))$. According to the chapeau of Article XX, legality of this depends on the measures meeting the WTO principles; the measures must be "not applied in a manner which would constitute a means of arbitrary or unjustifiable discrimination between countries where the same conditions prevail, or a disguised restriction on international trade”.

Article 2.2 of the TBT Agreement states that technical regulations must fulfil a legitimate objective, and lists protection of human health or safety, animal or plant life or health, or the environment as legitimate objectives. ${ }^{257}$ Two issues arise when examining whether a biofuels certification scheme would be consistent with Article 2.2. The first issue is whether the certification scheme pursues a legitimate objective. The second issue under Article 2.2 is whether the certification scheme is "necessary" to fulfil the legitimate objective.

\footnotetext{
${ }^{255}$ WTO http://www.wto.org/english/news_e/news09_e/climate_21dec09_e.pdf (Accessed 30 January 2011)

${ }^{256}$ Ibid (Accessed 30 January 2011).

257 TBT Agreement, above n 5, Article 2.2.
} 


\section{(a) Does certification fulfil a legitimate objective?}

The objective of a biofuels certification scheme is likely to be presented as the protection of human health or safety, animal or plant life or health, or the environment. Climate change and environmental degradation pose significant risks to human, animal and plant life. Previous dispute cases suggest that measures aimed at halting climate change, protecting endangered species and preventing pollution are measures necessary to fulfil legitimate objectives of protecting animal and plant life or health or the environment. For example, in the Brazil - Retreaded Tyres dispute, the Panel found that the Brazilian import ban on retreaded tyres was necessary for the legitimate objective of protecting animal and plant life or health in Brazil, through the reduction of air, water and soil pollution. ${ }^{258}$ Similarly, the Panel of the US-Gasoline dispute found that the US policy aimed at reducing air pollution from gasoline consumption was "within the range of those [policies] concerning the protection of human, animal or plant life or health”. ${ }^{259}$ As climate change results from a form of air pollution, it too would fall within the range of policies fulfilling this objective.

The objective of a biofuels certification scheme could also be presented as the conservation of natural resources according to Article XX(g) of the GATT. An important distinction between Articles XX(g) and XX(b) (and Article 2.2 of TBT) is that Article (b) requires the measures to be "necessary" to fulfil the objective, whereas Article (g) only requires that the measures "relate to" the objective, but must be effective in conjunction with restrictions on domestic production or consumption. Although this provides a wider scope for measures to be justified under Article XX(g), the Appellate Body has stated that the measures must not be disproportionately wide in reach or scope, and the measures should have a "substantial relationship” with the conservation of natural resources, not merely "incidentally or inadvertently aimed at” it. ${ }^{260}$

According to the Appellate Body, “exhaustible natural resources” includes both living and non-living natural resources, and has included clean air, migratory seas turtles, salmon and herring, tuna and dolphins. ${ }^{261}$ It is likely that biofuel sustainability measures that specifically aim to reduce the level of greenhouse gas in the atmosphere, to reduce water or

\footnotetext{
${ }^{258}$ Brazil - Measures Affecting Imports of Retreaded Tyres (12 June 2007). WT/DS332/R, para 7.83 (Panel Report).

${ }^{259}$ United States - Standards for Reformulated and Conventional Gasoline (29 January 1996). WT/DS2/R, 6.21 (Panel Report).

${ }^{260}$ Zarrilli, above n 92, 38.

${ }^{261}$ Condon, above n 201, 912.
} 
soil pollution, or to protect biodiversity would fall under the scope of policies that relate to the conservation of exhaustible natural resources and may be justified under Article XX(g).

Any biofuel certification criteria that relate to social conditions or food security would be more difficult to justify. It could be argued that such criteria relate to human health and safety, but the link between the measures and this objective would need to be substantiated. ${ }^{262}$ Although it would be easy to demonstrate that there is a link between high food prices and public health, showing that there is a substantial relationship between food security and biofuel production, and demonstrating that certification is necessary to address the problem, may prove difficult. The risk to human health of biofuel production is not as easily recognisable as the risk of, for example, products that contain asbestos, and significant scientific research would be needed for the risk to be recognised in the same way. Measures that relate to social conditions, such a labour standards and rural income opportunities, are not covered in the list of general exceptions in Article XX of the GATT or in the list of legitimate objectives in Article 2.2 of the TBT Agreement and would not be justified by these articles. $^{263}$

(i) Trans-boundary environmental protection

The above analysis has demonstrated that objectives such as mitigating risk relating to air pollution and preserving biodiversity would fall under the scope of policies that may be covered by Article XX of the GATT or Article 2.2 of the TBT Agreement. Biofuels certification schemes differ from other environmental policies in the sense that many aspects of the various schemes are designed for the purpose of environmental protection on a global scale (for example, measures to mitigate climate change) or for the purpose of protecting the environment in areas outside of the national boundaries of the Member imposing the measures (for example, protection of natural habitat in another country). Although the WTO clearly gives each member the right to implement measures as needed to protect its domestic environment, it is questionable as to how far a member can go in imposing environmental protection standards outside its national borders.

Compelling arguments can be made both for and against trans-boundary environmental protection measures. On the affirmative, some environmental issues are global in nature, and cannot be defined by national boundaries, for example pollution of the air and water, climate change, protection of migratory endangered species and protection of global biodiversity.

\footnotetext{
${ }^{262}$ Echols, above n 177, 14.

263 Ibid, 14.
} 
These types of issues cannot be addressed by one country acting alone within its own boundaries - cooperation and global effort are needed, and in some cases placing restrictions on environmentally damaging trade would be one way to encourage global compliance to standards designed to protect the environment. International environmental law has a long history of trans-boundary obligations, starting with the Trail Smelter case between the United States and Canada in 1941 which found Canada liable for the negative impact on the environment in the United States due to sulphur dioxide pollution. ${ }^{264}$ More recently, the Kyoto Protocol, opened for signature in 1998, commits signatory countries to collectively reduce their greenhouse gas emissions in an attempt to combat global climate change. Obligations are increasingly being placed on countries to take all reasonable measures to minimise environmental damage that may occur beyond their borders. ${ }^{265}$

On the other side of the argument, almost all trade will have an environmental impact, either through production of goods or through their transportation, and applying transboundary environmental policies could result in trade being blocked. Guidance would be needed on where it is, and is not, appropriate for one Member to impose its environmental protection policies on imported goods, particularly where there is no direct environmental impact within the importing country. Certification schemes that have been based on environmental or social conditions in a supplying country have resulted in strong criticism in the past. Developing countries in particular are concerned that such certification schemes are counterproductive to environmental and social protection in a supplying country. ${ }^{266}$ The WTO does not provide guidance on this issue in any of the agreements. However, the rulings of past dispute cases are an indication the WTO stance on this issue. The two disputes most central to this issue are United States - Tuna (I and II) and United States - Shrimp and Shrimp Products. ${ }^{267}$

\footnotetext{
${ }^{264}$ Ketabi, above n 4, 1926.

265 Ibid, 1928.

${ }^{266}$ Echols, above n 177, 12.

267 The United States - Tuna and United States - Shrimp cases have been analysed extensively, for further discussion of these cases see: Thomas Schoenbaum, "International trade and protection of the environment: The continuing search for reconciliation” (1997) 91 Am. J. Int’l L. 268; Richard Parker, "Use and abuse of trade leverage to protect the global commons: What can we learn from the tuna-dolphin conflict?” (2000) 12 Geo. Int'l Envtl L. Rev. 1.; Arthur Appleton “Shrimp/Turtle: Untangling the Nets” (1999) 2 J. Int'l Econ. L., 477.; John Knox, "Judicial resolution of conflicts between trade and the environment" (2004) 28 Harv. Envtl L. Rev. 1; Dominic Gentille, “International trade and the environment: What is the role of the WTO?” (2009-2010) 20 Fordham Envt'l L. Rev., 197.
} 


\section{$\underline{\text { United States - Tuna }}$}

The US - Tuna (I) case was brought against the United States by Mexico and other countries, in complaint of US regulations on tuna fishing methods designed to minimise negative impacts on dolphins. Dolphin protection standards, found in the US Marine Mammal Protection Act, were in place for the domestic US fishing fleet. The US denied access to imported tuna unless the exporting country was able to prove that their fishing fleet was meeting the dolphin protection standards set out in the Marine Mammal Protection Act. Mexico claimed that the import ban was inconsistent with Articles III, XI and XIII of GATT. $^{268}$ The US argued that, even if the import ban were otherwise inconsistent with other GATT provisions, it was justified under Article XX. ${ }^{269}$

In relation to the application of Article XX, Mexico asserted that: ${ }^{270}$

Nothing in Article XX entitled any contracting party to impose measures in the implementation of which the jurisdiction of one contracting party would be subordinated to the legislation of another contracting party. It could be deduced from the letter and spirit of Article XX that it was confined to measures contracting parties could adopt or apply within or from their own territory. To accept that one contracting party might impose trade restrictions to conserve the resources of another contracting party would have the consequence of introducing the concept of extraterritoriality into the GATT, which would be extremely dangerous for all contracting parties.

The Panel agreed with Mexico's assertion and concluded that GATT rules did not allow one country to attempt to enforce its own domestic laws in another country. The Panel considered that if Article XX(b) or XX(g) were applied in a extra-territorial manner, then each Member could "unilaterally determine the life or health protection policies from which other contracting parties could not deviate without jeopardizing their rights under the General Agreement. The General Agreement would then no longer constitute a multilateral framework for trade among all contracting parties but would provide legal security only in respect of trade between a limited number of contracting parties with identical internal regulations". 271

\footnotetext{
${ }^{268}$ United States - Restrictions on Imports of Tuna above n 244, para 3.1

${ }^{269}$ Ibid, para 3.27

${ }^{270}$ Ibid, para 3.31

${ }^{271}$ Ibid, para 5.27
} 
The Panel suggested that the US policy could be made compatible with GATT rules if Members agreed on amendments or reached a decision to waive the rules especially for this issue. That way, Members could negotiate the specific issues, and could set limits that would prevent protectionist abuse. ${ }^{272}$ The Panel also concluded that the labelling of products as "dolphin-safe" would allow consumers to make informed decisions on the purchase of tuna, without violating GATT rules. ${ }^{273}$ Interestingly, Mexico has subsequently initiated a dispute, claiming that US measures have the effect of prohibiting the labelling of Mexican tuna and tuna products as "dolphin-safe”. The dispute Panel has ruled that the US labelling measures are more trade-restrictive than necessary to fulfill their legitimate objectives, and are consequently inconsistent with Article 2.2 of the TBT Agreement. ${ }^{274}$

A similar case was brought by the EU against the US on the restriction on tuna imports according to the Marine Mammal Protection Act. The Panel in this dispute reached the same conclusions as the panel of the previous dispute with Mexico, that the US regulations were not covered by the exceptions in Article XX. ${ }^{275}$ The Panel decisions in these cases do not support the application of Article XX in an extra-territorial manner. If biofuels certification schemes were disputed, it is likely that - on the basis of the United States-Tuna decisions - many of the criteria contained in them would be considered inconsistent with the GATT.

\section{$\underline{\text { United States - Shrimp and Shrimp Products }}$}

This case was brought against the US by India, Malaysia, Pakistan and Thailand. The dispute involved the import bans imposed by the United States on shrimp that was harvested using methods that would lead to the accidental death of sea turtles, which were protected in US law under the Endangered Species Act of 1973. This Act prohibited capturing or killing sea turtles within the US territorial sea and the high seas, and required US shrimp trawlers to use specific equipment (turtle exclusion devices) when fishing. Concurrently, the US Public Law enacted in 1989 prohibited imports of shrimp which were not harvested under the methods required in the Endangered Species Act. Exporters who wished to avoid the ban had to obtain certification to ensure that shrimp was caught using the "turtle exclusion devices". This again raised the general question of whether a Member can set a measure conditioning

\footnotetext{
272 Ibid, para 6.3

273 Ibid, para 5.42

${ }^{274}$ United States - Measures Concerning the Importation, Marketing and Sale of Tuna and Tuna Products, above n 186, para 7.620 .

${ }^{275}$ United States - Restrictions on Imports of Tuna above n 244, para 6.1.
} 
market access on the adoption of certain environmental conservation policy by the exporting country.

The Panel supported the finding of the US - Tuna case, concluding that: ${ }^{276}$

In our view, if an interpretation of the chapeau of Article XX were to be followed which would allow a Member to adopt measures conditioning access to its market for a given product upon the adoption by the exporting Members of certain policies, including conservation policies, GATT 1994 and the WTO Agreement could no longer serve as a multilateral framework for trade among Members as security and predictability of trade relations under those agreements would be threatened. This follows because, if one WTO Member were allowed to adopt such measures, then other Members would also have the right to adopt similar measures on the same subject but with differing, or even conflicting, requirements. If that happened, it would be impossible for exporting Members to comply at the same time with multiple conflicting policy requirements. Indeed, as each of these requirements would necessitate the adoption of a policy applicable not only to export production (such as specific standards applicable only to goods exported to the country requiring them) but also to domestic production, it would be impossible for a country to adopt one of those policies without running the risk of breaching other Members' conflicting policy requirements for the same product and being refused access to these other markets.

Accordingly, the Panel found that the US measure for imported shrimp constituted unjustifiable discrimination between countries where the same conditions prevail and thus is not within the scope of measures permitted under Article XX. ${ }^{277}$

The United States subsequently appealed the Panel's interpretation of Article XX, stating that the Article does not mention the "multilateral trading system", nor conditions a Member's right to adopt a trade-restricting measure on the basis of hypothetical effects on that system. ${ }^{278}$ The Appellate Body reversed the Panel's finding that the US measures were not within the scope of Article XX, and proceeded to find that the measures "related to" the conservation of an exhaustible natural resource within the meaning of Article XX(g). ${ }^{279}$

\footnotetext{
${ }^{276}$ US - Import Prohibition of Certain Shrimp and Shrimp Products, above n 246, para 7.45.

${ }^{277}$ Ibid, para 7.49.

${ }^{278}$ US - Import Prohibition of Certain Shrimp and Shrimp Products (12 October 1998) WT/DS58/AB/R, para 12. (Appellate Body Report).

${ }^{279}$ Ibid, para 122 and 142.
} 
However, the measures were found to be applied in a way that was arbitrary and discriminated unjustifiably between Members, and therefore contrary to the chapeau of Article XX . ${ }^{280}$

The Appellate Body found that there was a sufficient nexus between the migratory and endangered sea turtles and the United States for purposes of Article XX(g), but did not decide whether there was a jurisdictional limit implied in the language of Article XX(g). This ruling could be extended to imply that, as the effects of climate change are global, there could be sufficient jurisdictional nexus between Members and climate change to justify measures for the purpose of conserving exhaustible natural resources. ${ }^{281}$ The ruling also implies that, at least in principle, Article XX could be used to allow Members to set import measures based on the environmental policies of other Members. However, in fulfilling the chapeau of Article XX, such a measure could not be imposed without consideration of local conditions and consultation at the bilateral or multilateral level. ${ }^{282}$ In the US - Shrimp case, the US measures were supported by reference to an international agreement that allowed Members to take actions to protect animals, whether they are located within or outside their jurisdiction. Similarly, multilateral agreements on climate change could be referenced to support the view that the climate system is an exhaustible natural resource, and measures could be taken by Members outside their jurisdiction in order to protect it. If an international agreement were to exist specifically for biofuel production, this could support other biofuel certification measures that aim to protect the environment or human health, provided that there is a relationship between the design of the measure and the policy goal, and it is applied in a way that is not arbitrary or discriminatory.

\section{(b) Is certification necessary?}

If it is determined that biofuel certification is fulfilling a legitimate objective that is within the scope of Article 2.2 of the TBT Agreement or Article XX of the GATT, it must still be proven that certification is necessary to achieve that objective. The measures imposed must be no more trade restrictive than necessary and must not be applied in an arbitrary or discriminatory manner. Also, if an import measure is to be justified under Article XX(g), it must be applied "in conjunction with restrictions on domestic production or consumption". 283

\footnotetext{
${ }^{280}$ Ibid, para 184.

${ }^{281}$ Condon, above n 201, 913.

${ }^{282}$ Howse, above n 24, 29.

${ }^{283}$ GATT, above n 182, Article XX.
} 
The Appellate Body has suggested that the term "necessary" includes an assessment of whether there are other WTO-consistent measures that are available and effective in achieving the policy goal. ${ }^{284}$ Alternative measures may be available that achieve the objective in a less trade restrictive manner; identification of these measures is likely to require consultation or negotiation with other WTO Members. ${ }^{285}$ If a certification scheme is too rigid and inflexible in considering the different conditions in different countries, this could be interpreted as trade restrictive. This may become complicated if several countries implement unilateral biofuel certification schemes with differing measures. Some flexibility in adopting measures of alternative certification schemes would be beneficial, as has been done with the RTFO scheme developed by the UK.

The contribution of the measure to the achievement of the policy goal is also taken into consideration, which may require scientific evidence. ${ }^{286}$ In the case of wide reaching goals such as mitigation of climate change, it would be difficult to show that the measure is essential, particularly as it may contribute as one part of a package of policy initiatives. Additionally, the positive environmental effects of biofuels and their contribution towards environmental goals may be challenged by stakeholders. Nonetheless, the Appellate Body has shown some flexibility in demonstrating the "necessity" of environmental measures. For example, in the Brazil - Retreaded Tyres dispute, the Appellate Body recognized that the measure in question was part of a comprehensive policy aimed at achieving the objective (reducing air pollution). The contribution that the measure would make to achieving the objective could only be evaluated with the benefit of time. The Appellate Body nonetheless found that the measure would produce a material contribution to the achievement of the objective. $^{287}$ In determining whether or not a measure is necessary, the "risks of nonfulfilment” should be taken into account. If a measure is presented as part of a comprehensive strategy, the effect of removing it from the overall package needs to be taken into consideration. ${ }^{288}$ Although there are other methods of achieving policy goals relating to biofuels sustainability, the case could be made that certification is a central part of a policy strategy. However, this argument depends on other policies being in alignment with the overarching goal, which - as described in Chapter III - is not always the case.

\footnotetext{
${ }^{284}$ United States - Measures Affecting the Cross-Border Supply of Gambling and Betting Services (7 April 2005) WT/DS285/AB/R, para 315 (Appellate Body Report).

${ }^{285}$ Condon, above n 201, 924

${ }^{286}$ Ibid, 925.

${ }^{287}$ Brazil - Measures Affecting Imports of Retreaded Tyres, above n 258.

${ }^{288}$ Condon, above n 201, 915.
} 
There is some contention as to what aspect of a measure should be examined under the "necessity" requirement - should it be the measure itself (for example, a certification scheme), or the differential treatment of that measure (for example, a differential tax applied to certified and uncertified products). The Appellate Body in the Thailand - Cigarettes case recently stated (in relation to Article $\mathrm{XX}(\mathrm{d})$ ) that it is the differential treatment under the measure in question must be necessary to achieve the policy goal. ${ }^{289}$ This is in contradiction to previous findings, which have examined the measures themselves rather than the differential treatment. ${ }^{290}$ Appellate Body analysis of environmental measures, under Articles $\mathrm{XX}$ (b) and $\mathrm{XX}(\mathrm{g})$, is consistent in examining the measures themselves. The inconsistency arises in the analysis of Article $\mathrm{XX}(\mathrm{d})$, which relates to measures that are "necessary to secure compliance with laws or regulations which are not inconsistent with the provisions of this Agreement”. 291

\section{Conclusions}

This chapter has explored the key issues concerning the consistency of biofuels certification schemes with WTO agreements. The analysis has highlights two areas that could be problematic, and has come to the following conclusions:

- Consistency with article 2.1 of the TBT agreement and Articles I and III of the GATT relies on biofuels that are certified as sustainably produced being considered to be "unlike" biofuels that are not certified. The two types of products could only be considered "unlike" if the method of production is taken into account.

- None of the four factors historically used by the Appellate Body to determine "likeness” could be relied on for demonstrating that certified and uncertified biofuels are not like products.

o In terms of physical characteristics, the risk associated with uncertified biofuels could be described as an aspect of the "quality" of the biofuel could

\footnotetext{
289 Thailand - Customs and Fiscal Measures on Cigarettes from the Philippines (17 June 2011) WT/DS371/AB/R, para 179 (Appellate Body Report)

${ }^{290}$ For example United States - Standards for Reformulated and Conventional Gasoline, above n 204; Brazil Measures Affecting Imports of Retreaded Tyres, above n 258.

291 The "measures" versus "treatment" question appears to be a problem specific Article XX(d), where the measure being examined could be the same as the "law or regulation". For example, the measure in question for the Thailand - Cigarettes case was the application of Value-Added Tax (VAT) to cigarettes, and the differential treatment related to the different requirements for imported and domestic cigarettes. In this instance, it does not make sense to ask if the application of VAT to cigarettes is necessary to secure compliance with the relevant law or regulation (the VAT regime itself). An article XX(d) defence would only make sense if the "differential treatment" is examined, with the question of whether the differential treatment is necessary to secure compliance with the VAT regime.
} 
be used as a way to distinguish two otherwise "like" biofuels. However, environmental risks and other risks are generally addressed under Article XX of the GATT.

o The end uses of certified and uncertified biofuels are likely to be identical or mostly overlapping. The fact that two products have the same end uses is likely to undermine any argument that they are not "like".

o In terms of consumer habits, individual consumers are unlikely to know the source or method of production of the biofuel being used. Retail consumers may be influenced by certification, but are likely to also be influenced by cost, and - due to tax incentives and blending requirements - it would be impossible to distinguish between the two possible motives for a retailer to purchase certified biofuel.

o The categorisation of biofuels under the HS system is complicated, with ethanol and biodiesel being classified differently. Although the different classifications may support a decision that different types of biofuels are not "like" products, the classifications are not aligned with whether biofuels are sustainably produced.

o If biofuels were classified as environmental goods, on the condition of being certified as sustainably produced, this would support an argument that certified and uncertified biofuels are not "like" products. There is debate about whether biofuels should be classified in this way, and the development of internationally agreed criteria for certification would likely assist in discussions on their classification as environmental goods.

- If certified and uncertified biofuels are considered to be "like" products, Article XX of the GATT could provide justification for the discriminatory certification measures. This article permits governments to restrict trade when necessary to protect the environment.

- Consistency with Article XX of the GATT and Article 2.2 of the TBT Agreement relies on determining whether certification schemes pursue a legitimate objective, and whether the certification is "necessary" to fulfil the legitimate objective.

- Biofuel sustainability measures that specifically aim to reduce the level of greenhouse gas in the atmosphere, to reduce water or soil pollution, or to protect biodiversity would fall under the scope of policies that relate to the protection of human, animal or 
plant life or health, or the conservation of exhaustible natural resources. They would therefore be justified as pursuing a legitimate objective. Certification criteria that relate to social conditions or food security would be more difficult to justify.

- Certification could be shown to be "necessary" to fulfil the legitimate objective. Although certification would be only one part of a package of policy initiatives (and its contribution may be questioned by stakeholders), the Appellate Body has in the past shown considerable flexibility in demonstrating the necessity of environmental measures

- However, it is questionable whether a member has the right to impose environmental protection standards outside its national boundaries.

o The rulings of a previous dispute case (US - Shrimp) imply that, at least in principle, there could be sufficient jurisdictional nexus between members and climate change to justify measures for the purpose of conserving exhaustible natural resources.

o Measures could not be imposed without consideration of local conditions and consultation at the bilateral or multilateral level. In the US - Shrimp case, the measures were supported by reference to international agreements that allowed members to take actions to protect certain animals, whether they are located within or outside their jurisdiction.

An international agreement specifically relating to biofuel production, if one were to exist, could support biofuel certification measures that aim to protect the environment or human health, provided that there is a relationship between the design of the measure and the policy goal, and it is applied in a way that is not arbitrary or discriminatory. There are current international agreements that relate to some of the specific criteria used in biofuels certification - including reduction of greenhouse gases, protection of biodiversity, and labour conditions. An analysis of multilateral agreements relating to climate change would need to be done to determine if they could be referenced to support biofuel certification measures. The following chapter examines these agreements to determine their applicability or otherwise to biofuel certification. 
The issues outlined in the previous chapters demonstrate that there is a need to review and coordinate the policies relating to biofuel production and trade. Government measures taken to encourage the production of biofuel have resulted in industry growth, but with little initial consideration given to the associated environmental impacts. Additionally, the assumption that the use of biofuel will result in a reduction in greenhouse gas emissions is being challenged.

Biofuels certification schemes, although addressing some of the sustainability concerns, currently lack international coordination or regulation. This lack of coordination raises a number of concerns. Firstly, producers and exporters of biofuels and biofuel feedstocks will face increasing costs associated with certification, and increasing bureaucratic complexity and regulatory burden particularly if different certification schemes require different measures. A second concern is that the increasing regulations associated with biofuel trade could result in a system that is incompatible with the WTO agreement.

Potential solutions to the lack of international cooperation are beginning to emerge. For example, the European countries have made an effort to harmonise the criteria of the certification schemes, which is evident in the similarities between schemes developed by the UK, Germany and the Netherlands. The certification initiatives developed by the European Union and Germany both explicitly acknowledge the need for fair trade and compliance with WTO rules, stating that sustainability criteria are to be applied to imported and domestically produced biofuels in a non-discriminatory way. However, in the absence of an international standard for biofuels production, certification regulations may be challengeable as inconsistent with the TBT Agreement.

The previous chapter discussed dispute cases where international environmental agreements were cited to provide support for environmental measures. If the measures are widely accepted in the international community and have been developed through broad consultation, taking into account the variety of conditions in different countries, it should be easier for a respondent to establish that the measures are fulfilling a legitimate objective and are non-discriminatory. ${ }^{292}$ Without the backing of an international standard, some certification regulations may be challengeable as inconsistent with the MFN principle and National Treatment obligations. Although there is currently no international standard for

${ }^{292}$ Howse, above n 24, 27. 
biofuels, some certification schemes may reference more general international standards; for example, the Swiss Mineral Taxation Law cites the International Labour Organization in setting acceptable social conditions for biofuel production. ${ }^{293}$ Other international agreements, such as those relating to climate change, may additionally qualify as relevant to some certification schemes.

This chapter looks at what constitutes an international standard according to the TBT Agreement. Recent dispute cases have explored the use of international standards in setting technical regulations. The resulting jurisprudence has provided some guidance on the definition of an international standard, when an international standard is considered to be relevant to a particular regulation, and the circumstances where technical regulations should be reviewed to ensure international standards are taken into account. There is less guidance available on determining when an international standard has or hasn't been used as a basis for a regulation, and when a standard should or shouldn't be used as a basis for a technical regulation. The Appellate Body appears to use a case-by-case determination of when an international standard has been applied appropriately to a technical regulation. These issues are expanded in the first part of this chapter. The second part of the chapter examines existing international agreements for their potential relevancy to biofuels certification and discusses how these international agreements could influence the development of biofuels certification schemes. This chapter considers - if a new international agreement for biofuels should be developed - which of the sustainability criteria would need to be included, and which are already covered by existing agreements, or could be covered with amendments to existing agreements.

\section{A The TBT Agreement and international standards}

The WTO itself does not set international standards, but in some situations it has a role in ensuring fair implementation of internationally agreed standards. The WTO agreement encourages the development and application of international standards through the TBT Agreement, which recognises the important contribution that international standards can make in improving efficiency of production and facilitating the conduct of international trade. ${ }^{294}$ Although Members are entitled to introduce measures that are not based on a relevant international standard in some circumstances, the emphasis on international

\footnotetext{
293 Steenblick, above n 155, 35-36.

294 TBT Agreement, above n 5.
} 
standards in various TBT Articles raises the status of international standards, and the bodies that develop them. Article 2.4 of the TBT Agreement states that: ${ }^{295}$

"Where technical regulations are required and relevant international standards exist or their completion is imminent, Members shall use them, or the relevant parts of them, as a basis for their technical regulations except when such international standards or relevant parts would be an ineffective or inappropriate means for the fulfilment of the legitimate objectives pursued, for instance because of fundamental climatic or geographical factors or fundamental technological problems.”

Further, Article 2.5 of the TBT Agreement states that "whenever a technical regulation is prepared for one of the legitimate objectives and is in accordance with relevant international standards, it shall be rebuttably presumed not to create an obstacle to trade".296 This article effectively shifts the burden of proof onto the complainant if an international standard is used. Article 2.6 encourages Members to participate in the preparation by appropriate international standardising bodies of international standards, within the limits of their resources. ${ }^{297}$

There is some debate as to the conditions under which a standard would be recognised as an "international standard" under the TBT Agreement. Several questions arise from the TBT Articles outlined above. For example, when and how does a standard become an "international standard" and which bodies are qualified to develop an international standard? When is an international standard considered to be "relevant" to a particular measure, and how can it be determined if an international standard has been used "as a basis" for a domestic measure?

1 Recognition of a standard as an "international standard"

Annex 1 of the TBT Agreement does not provide a definition for "international standard”, but it does define an "international body or system" as a "body or system whose membership is open to the relevant bodies of at least all Members”. ${ }^{298}$ Unlike the Sanitary

\footnotetext{
295 Ibid., Article 2.4.

${ }^{296}$ Ibid, Article 2.5

${ }^{297}$ Ibid, Article 2.6

298 Ibid, Annex 1, 4.
} 
and Phytosanitary (SPS) Agreement, ${ }^{299}$ the TBT Agreement is not associated with a specific standard setting body. The SPS Agreement specifies the Codex Alimentarius Commission, the International Office of Epizootics, and the International Plant Protection Convention as international standard setting bodies, but other standard setting bodies may be recognised if their membership is open to all WTO Members, and the SPS Committee identifies them as relevant. ${ }^{300}$

The Code of Good Practice for the Preparation, Adoption and Application of Standards (Annex 3 to the TBT Agreement) provides guidelines for the development of standards at all levels of governance. Article 4.1 of the TBT Agreement requires central government standardising bodies to comply with the Code of Good Practice. Other standardising bodies are not required to comply, but they are encouraged to do so, and those bodies that do comply with the Code of Good Practice are acknowledged as complying with the principles of the TBT Agreement. ${ }^{301}$ Additionally, the TBT Committee has released principles for the development of international standards. ${ }^{302}$ Both the Code of Good Practice and the principles state that standardising bodies should adhere to principles such as transparency, consensus, harmonisation and inclusion of all relevant parties in the development of the standard. Neither document requires consensus, but both recommend that bodies make every effort to achieve consensus on the standards they develop. In the United States - Measures Concerning the Importation, Marketing and Sale of Tuna and Tuna Products dispute case, the Panel confirmed that consensus is not an element of the definition of an international standard. ${ }^{303}$

Determining the definition of "international standard" is important to ensure common understanding of TBT Articles 2.4 and 2.5, ${ }^{304}$ which encourage the adoption of international standards where relevant. ${ }^{305}$ Although the TBT Agreement does not provide definitive advice on what constitutes an international standard, we can deduce that to qualify, an international

\footnotetext{
299 Agreement on the Application of Sanitary and Phytosanitary Measures (15 April 1994), Article 12.4. International standards relating to the SPS Agreement are set by relevant bodies in the Food and Agriculture Organization of the UN.

${ }^{300}$ Ibid., Annex A. To date, no other standardising bodies have sought recognition, see Steven Bernstein and Erin Hannah, "Non-state global standard setting and the WTO: legitimacy and the need for regulatory space" (2008) 11(3) Journal of International Economic Law, 594.

301 TBT Agreement, above n 5, 4.2.

${ }^{302}$ Committee on Technical Barriers to Trade, above n 136.

${ }^{303}$ United States - Tuna, above n 186, para 7.676.

${ }^{304}$ Humberto Zuniga Schroder, "Definition of the concept "international standard" in the TBT Agreement" (2009) 43(6) Journal of World Trade.

${ }^{305}$ Bernstein, above n 300, 584.
} 
standard should be developed in accordance with the Code of Good Practice and principles released by the TBT Committee, and should be developed by a body that is open to all WTO Members. International standards for biofuels, if developed in this way and applied to certification schemes, would address many concerns about the consistency and international coordination of certification. The application of such standards should also shield the country implementing a certification scheme from dispute.

For reasons of practicality, a standard setting body needs to have the capability to both fulfil the principles outlined above, as well as develop international standards that appropriately reflect market realities and the status of existing technologies. A standard setting body would need to have systems in place to assess proposals for standards, prepare new standards, seek input from relevant parties, resolve any disagreements between parties, and seek approval from member bodies. ${ }^{306}$ Schroder identifies international organisations that are capable of developing international standards, as well as being recognised by the WTO. These organisations include, amongst others, the Food and Agriculture Organization (FAO), the International Organization of Legal Metrology, the International Organization for Standardization, the International Geographical Union, the International Atomic Energy Agency, the International Labour Organization, the World Meteorological Organization and the World Health Organization. ${ }^{307}$

An international environmental agreement may contain standards that would qualify as international standards, and in some cases, an international agreement itself may qualify as international standard, if it relates specifically to, and is used as a basis for a technical regulation or describes the fundamental principle behind a technical regulation. ${ }^{308}$ In other situations, an international agreement may set targets or objectives that lead to the development of standards by a specific body. The recognition by WTO Members of a range of international environmental agreements as international standards or standard setting bodies would assist in harmonization and help to ensure that domestic measures (if in line with international agreements) are consistent with TBT obligations. ${ }^{309}$

\footnotetext{
${ }^{306}$ Schroder, above n 304, 1232; Bernstein, above n 300, 598.

${ }^{307}$ Schroder, above n 304, 1226-1227.

${ }^{308}$ Condon, above n 201.

309 Jan McDonald, "Domestic regulation, international standards, and technical barriers to trade” (2005) 4(2) Journal of World Trade, 271.
} 
The TBT Agreement only requires members to use international standards as a basis for their technical regulations if the international standard is relevant to the technical regulation. The TBT Agreement itself does not provide advice as to when an international standard is "relevant", and the best guidance to date comes from WTO disputes. In the ECTrade Descriptions of Sardines dispute, both the Panel and the Appellate Body found that the EC violated Article 2.4 of the TBT Agreement for not using the relevant international standard - developed by the Codex Alimentarius Commission - for labeling canned sardines and sardine-like products. ${ }^{310}$ The Panel, for the purposes of Article 2.4, stated that an international standard is relevant to a domestic technical regulation if it bears upon, relates to, or is pertinent to the same subject matter. ${ }^{311}$ This approach was also followed by the Panel in the United States - Measures Concerning the Importation, Marketing and Sale of Tuna and Tuna Products dispute case. ${ }^{312}$ Determining whether an international standard is "relevant” to a particular technical regulation is likely to require evaluation on a case-by-case basis in the context of the TBT Agreement. ${ }^{313}$

The EC-Sardines case also clarified a few related issues. First, the Appellate Body and the Panel confirmed that an international standard does not have to be adopted by consensus to qualify as a relevant international standard. ${ }^{314}$ Second, the Appellate Body and the Panel asserted that Members have an obligation to reassess existing technical regulations as new international standards are developed. Also, Members are obliged to ensure that technical regulations predating the TBT Agreement are reviewed in light of relevant international standards. ${ }^{315}$ This is consistent with TBT Article 2.3 which requires Members to review existing product requirements on a regular basis to assess whether they are still necessary and whether a less trade restrictive measure might serve the same ends. Such reviews would sensibly evaluate any new international standards. ${ }^{316}$

\footnotetext{
310 European Communities - Trade Description of Sardines (26 September 2002) WT/DS231/AB/R, para 315 (Appellate Body Report).

${ }^{311}$ European Communities - Trade Description of Sardines (29 May 2002) WT/DS231/R, para 7.69 (Panel Report; European Communities - Trade Description of Sardines, above n 310, 230.

${ }^{312}$ United States - Measures Concerning the Importation, Marketing and Sale of Tuna and Tuna Products, above n 186, para 7.700 .

313 Bernstein, above n 300, 587.

${ }^{314}$ European Communities - Trade Description of Sardines, above n 310, 227.

315 Ibid., 205; McDonald, above n 309, 258.

${ }^{316}$ McDonald, above n 309, 260.
} 
Once an international standard has been developed and is determined to be relevant to a technical regulation, the TBT Agreement requires that the international standard be used "as a basis for” the technical regulation. The Appellate Body has stated that a technical regulation does not need to conform to the international standard. ${ }^{317}$ The EC-Sardines dispute clarified that if a technical regulation stands, is founded on, or built on, or supported by an international standard, this is sufficient to determine that the regulation is based on the international standard. This requires that a "strong and very close relationship" is formed between the two, and the international standard is the "principal constituent", "fundamental principle”, or "determining principle" of the national measure. ${ }^{318}$ The measure should not be inconsistent or contradictory to the international standard. ${ }^{319}$ Problems could arise when a dispute panel or the Appellate Body needs to determine the relationship between an international standard and a technical regulation, without necessarily having the technical knowledge to do so. According the WTO Dispute Settlement Understanding, Panels may seek additional information or consult with experts as needed. ${ }^{320}$ McDonald suggests that the Panel should consult the standard setting body when determining if a technical regulation is based on an international standard. ${ }^{321}$ This seems to be a sensible way to ensure that the meaning and purpose of the international standard is properly understood in the context of a dispute. McDonald also notes that the Panel in the EC-Sardines dispute did not consult with Codex on the meaning of the relevant standard, despite requests by the EC to do so. ${ }^{322}$

\section{$4 \quad$ Circumstances where a relevant international standard need not be used - burden of proof}

The TBT Agreement allows Members to decide not to base their technical regulations on relevant international standards in circumstances where the international standard would be "an ineffective or inappropriate means for the fulfillment of the legitimate objectives pursued, for instance because of fundamental climatic or geographical factors or fundamental technological problems”. ${ }^{323}$ The Appellate Body in the EC-Sardines dispute ruled that the burden of proof lies on the complainant to demonstrate that the international standard is

\footnotetext{
${ }^{317}$ European Communities - Trade Description of Sardines, above n 310, 242.

318 Ibid., 245.

${ }^{319}$ Ibid., 248.

${ }^{320}$ Understanding on Rules and Procedures Governing the Settlement of Disputes (15 April 1994), Article 13.

${ }^{321}$ McDonald, above n 309, 269.

322 Ibid., 269.

${ }^{323}$ TBT Agreement, above n 5, Article 2.4
} 
effective and appropriate to achieve the legitimate objective of the technical regulation. ${ }^{324}$ This may make it easier for Members to set measures that are more stringent than the international standard. ${ }^{325}$ The panel stated that "in the context of Article 2.4, an ineffective means is a means which does not have the function of accomplishing the legitimate objective pursued, whereas an inappropriate means is a means which is not specially suitable for the fulfilment of the legitimate objective pursued". ${ }^{326}$ As established by the Appellate Body in that case, the appropriateness of the standard and the effectiveness of the standard can be interrelated depending on the nature of the objectives of the regulation under examination. ${ }^{327}$ The Panel in the US - Certain Country of Origin Labelling (COOL) Requirements case followed this approach in examining if the complainant (Mexico) had established that the relevant international standard was an effective and appropriate means for the fulfillment of the legitimate objective pursued by the United States. ${ }^{328}$

The final part of Article 2.4 identifies that standards may be inappropriate or ineffective due to "fundamental geographical or climatic factors or fundamental technological problems”. Although the list is not exhaustive, it notably leaves out some important factors that may make an international standard inappropriate or ineffective, including cultural preferences or level of risk tolerance. ${ }^{329}$ This part of Article 2.4 was not examined in the ECSardines case or the US - Certain Country of Origin Labelling (COOL) Requirements case, so the possible range of reasons for rejecting an international standard remains largely unexplored.

\section{$5 \quad$ Summary}

The above analysis shows that the TBT Agreement requires Members to use international standards where they are accepted as international standards, where are relevant to a technical regulation, and where they will be effective and appropriate in achieving the legitimate objective pursued. An international standard is likely to be accepted by the TBT Committee if it has been developed in accordance with the Code of Good Practice and TBT principles, and if it is open to all WTO Members. The standard will be considered relevant if it bears upon, relates to, or is pertinent to the subject matter. An international standard must

\footnotetext{
${ }^{324}$ European Communities - Trade Description of Sardines, above n 310, 282.

${ }^{325}$ McDonald, above n 309, 263.

${ }^{326}$ European Communities - Trade Description of Sardines, above n 311, 7.116.

${ }^{327}$ European Communities - Trade Description of Sardines, above n 310, 289.

328 United States - Certain Country of Origin Labelling (COOL) Requirements (18 November 2011) WT/DS384/R and WT/DS286/R, para 7.724 (Panel Report).

${ }^{329}$ McDonald, above n 309, 264.
} 
be demonstrated to be not ineffective or inappropriate to the regulation in question. The following section examines international agreements and standards that may qualify as "relevant international standards" to the technical regulations of biofuels certification schemes.

\section{B Analysis of certification schemes and relevant international agreements}

Biofuels certification schemes contain various criteria which may relate to different international agreements and standards. The certification schemes referred to in this chapter are those developed by national or regional governments, and those schemes that are most developed and ready for implementation. The analysis focuses of the sustainability criteria that are most commonly included in these certification schemes. The criteria examined relate to greenhouse gas savings, protection of biodiversity, other environmental concerns, food security and human rights and labour conditions. The general characteristics of these schemes were covered in Chapter III. Further detail is also provided in Appendix one.

The international agreements examined include UN Framework Convention on Climate Change, the Kyoto Protocol, the Ramsar Convention on Wetlands of International Importance, the Convention on Biological Diversity, the Declaration of the United Nations Conference on the Human Environment the Rio Declaration and the International Labour Organization Conventions.

For each criterion identified, possible relevant international agreements were identified and examined and the regulations of each compared to the certification schemes. The following sections include commentary on the relevancy of the agreements in terms of addressing biofuels sustainability criteria, including suggestions on how an agreement could be changed or extended to incorporate the concerns about biofuel production.

\section{Relevant international agreements relating to greenhouse gas emissions}

International agreements relevant to greenhouse gas emission savings are the UN Framework Convention on Climate Change, the Kyoto Protocol and the Ramsar Convention.

\section{(a) UN Framework Convention on Climate Change and Kyoto Protocol}

The aim of the UN Framework Convention on Climate Change (UNFCCC) is to ensure that ecosystems, food production systems and economic development are not threatened by climate change. In order to achieve this, greenhouse gases in the atmosphere 
need to be stabilised at a level that would prevent dangerous anthropogenic interference with the climate system. ${ }^{330}$ The UNFCCC was signed in 1992, currently lists 192 countries as signatories, and membership is open to all WTO Members. ${ }^{331}$ Given its openness and large number of signatories, it is likely that the UNFCCC would be considered an international body by the TBT Committee. It has appropriate mechanisms for standard setting, including technical advisory bodies and consultation processes. As stated in the previous section, a standard developed by a technical body of the UNFCCC would need to follow the Code of Good Practice and the TBT principles to be considered an international standard for TBT purposes.

The UNFCCC does not mention the use of renewable fuels as a method for reducing greenhouse gas emissions, but sets high level principles and commitments for the parties to prevent or minimise the effects of climate change. The Parties are required to formulate and implement programmes containing measures to reduce greenhouse gas emissions, and to report on their anthropogenic emissions. This includes promoting the development and use of technologies that control, prevent or reduce anthropogenic emissions. ${ }^{332}$ The Kyoto Protocol to the United Nations Framework Convention on Climate Change (Kyoto Protocol, signed in 1998) quantifies the emission reduction commitments of each Party.

The UNFCCC establishes a conference of the Parties, the scope of which includes facilitating the coordination of measures adopted by Parties to address climate change and its effects. This covers the development and refinement of comparable methodologies for preparing inventories of greenhouse gas emissions by sources, and evaluating the effectiveness of measures to limit emissions and evaluating the environmental, economic and social impacts of measures. ${ }^{333}$ A Subsidiary Body for Scientific and Technical Advice is established under Article 9 to provide scientific assessments on the effects of measures, amongst other things.

The Kyoto Protocol further elaborates on the commitments of the Parties to implement policies and measures to limit greenhouse gas emissions, ${ }^{334}$ and the Parties should strive to do so in such a way as to minimise adverse effects on international trade and social,

\footnotetext{
${ }^{330}$ United Nations Framework Convention on Climate Change (hereafter UNFCCC) (1992), Article 2.

331 UNFCCC. http://unfccc.int/essential_background/feeling the heat/items/2913.php. Accessed 2 October 2011.

${ }^{332}$ UNFCCC, above n 330, Article 4.1.

${ }^{333}$ Ibid, Article 7.2

${ }^{334}$ Kyoto Protocol to the United Nations Framework Convention on Climate Change (1998), Article 2.1.
} 
environmental and economic impacts on other Parties. ${ }^{335}$ The scope of the policies and measures includes promoting research, development and use of new and renewable forms of energy and environmentally sound technologies. The Protocol states that Parties should cooperate to exchange information on such policies and measures, including developing ways of improving their comparability, transparency and effectiveness. ${ }^{336}$ Article 5.2 states that methodologies for estimating emissions - for the purpose of ensuring that Parties do not exceed their assigned amounts - should be those that are accepted by the Intergovernmental Panel on Climate Change.

\section{(b) Ramsar Convention}

The Ramsar Convention on Wetlands of International Importance Especially as Waterfowl Habitat was originally signed in 1971 and amended in 1982 and 1987. It aims to protect wetlands, in recognition of their importance in regulating water regimes, as habitat for waterfowl and other wildlife, and their irreplaceable economic, cultural, scientific, and recreational value. It currently has 160 Contracting Parties and is open to all WTO Members. The Convention defines wetlands as: ${ }^{337}$

Areas of marsh, fen, peatland or water, whether natural or artificial, permanent or temporary, with water that is static or flowing, fresh, brackish or salt, including areas of marine water the depth of which at low tide does not exceed six metres.

Under the Convention, each Party designates suitable wetlands within its territory for inclusion in a List of Wetlands of International Importance. ${ }^{338}$ Almost 2000 sites have been included on this list. ${ }^{339}$ Subsequent articles of the Convention relate to the conservation and management of the listed wetlands.

Although the text of the Convention does not refer to the value of wetlands in storing carbon, the relationship between wetlands and climate change is recognised, and the Ramsar Convention secretariat has prepared a paper on this issue for the fifth UNFCCC Conference of the Parties. ${ }^{340}$ The usefulness of the Convention in the context of biofuels certification is in

\footnotetext{
335 Ibid, Article 2.3

${ }^{336}$ Ibid, Article 2.1.

337 Ramsar Convention on Wetlands on International Importance Especially as Waterfowl Habitat (1987), Article 1.

${ }^{338}$ Ibid, Article 2.

${ }^{339}$ Ramsar Convention website. http://www.ramsar.org/cda/en/ramsar-may40thkeymessage/main/ramsar/1 per cent5E25116_4000_0 _ Accessed 2 October 2011.

${ }^{340}$ Ramsar Convention website, above n 339.
} 
providing an internationally agreed definition of wetlands (which includes peatlands), and a list of areas that are considered wetlands, in particular for certification schemes that prohibit the use of wetlands and peatlands for biofuel production (the RED and German Biofuel Ordinance).

\section{(c) Applicability to biofuels certification criteria}

A common goal of many certification schemes is assurance that the biofuels produced and used will result in a reduction in greenhouse gas emissions, compared to the emissions that would result if fossil fuels had been used in the place of biofuels. Certification schemes may list the level of greenhouse gas savings to be achieved, methods of measuring greenhouse gas savings or a set level assumed for each feedstock and/or production method. Additionally, some certification schemes exclude certain feedstocks or methods of production for qualifying for certification, on the assumption that the level of greenhouse gas savings is unlikely to be sufficient. Examples of certification schemes that contain greenhouse gas savings criteria are:

- The European Renewable Energy Directive (RED) lists one of its goals as reducing greenhouse gas emissions and complying with the Kyoto Protocol to the UN Framework Convention on Climate Change, through the increased use of energy from renewable sources, together with energy savings and increased energy efficiency. ${ }^{341}$ The RED acknowledges that, if greenhouse gas savings are to be achieved through biofuel production, there must be clear rules for the calculation of the greenhouse gas emissions associated with them. It proposes that initially a list of default values should be used and the list updated as more reliable data becomes available. Nonetheless, individual operators can claim a level of greenhouse gas saving below the level shown on the list if they can adequately demonstrate this. ${ }^{342}$ The RED also specifies that changes in land use must be taken into consideration in calculating the greenhouse gas emission savings of biofuels. For example, biofuels should not be produced from wetlands, peatlands or continuously forested areas. The RED states that the work of the Intergovernmental Panel on Climate Change is the appropriate body to set such

\footnotetext{
${ }^{341}$ Renewable Energy Directive, above n 128, paragraph 1.

${ }^{342}$ Ibid, paragraphs 80-82.
} 
standard values. $^{343}$ The regulations for wetlands in the European RED are built on and supported by the definition of wetlands provided by the Ramsar Convention.

- The German Sustainability Ordinance for Biofuels is consistent with the European Directive, outlined above, in its requirements for greenhouse gas emission savings, calculation of greenhouse gas emissions and specifications regarding changes in land use. ${ }^{344}$

- A key objective of the UK Renewable Transport Fuel Obligation (RTFO) is to drive carbon reductions in the transport fuels supplied into the UK. The RTFO contains a requirement for suppliers to report on the greenhouse gas savings of biofuels purchased. ${ }^{345}$ It is not yet mandatory for suppliers to meet a standard, but only to report against it and failure to report makes the supplier ineligible for RTFO certificates. The Renewable Fuels Agency (RFA) has released technical guidance for carbon reporting, including default values for greenhouse gas emission savings. ${ }^{346}$ For those who don't wish to rely on the default values (which the RFA admits are set at a high level), the RFA provides a Carbon Calculator tool to determine the carbon intensity of biofuels. ${ }^{347}$ The RTFO takes a meta-standard approach in which existing standards and certification schemes can be used to demonstrate that that the requirements set out by the RTFO have been met.

- With the aim of meeting requirements (under the Kyoto protocol) to reduce CO2 emissions, the Swiss Mineral Oil Taxation Law was amended in 2008 to give tax benefits to biofuels, both imported and domestically produced. The tax exemption however, only applies to biofuels which meet certain environmental and social criteria. $^{348}$ Specifically, the amended Law states that biofuels must generate 40 per cent less greenhouse gas than gasoline, calculated on a life-cycle basis. It is considered that fuels from palm oil, soybeans and grains do not meet the required level of greenhouse gas savings. ${ }^{349}$

\footnotetext{
${ }^{343}$ Ibid, paragraphs 70-71.

${ }^{344}$ Bioliquids Ordinance, above n 137, Article 8. An English translation of the Biofuels Quota Act is not available, therefore information in this section is drawn from the bioliquids ordinance as the requirements are the same.

${ }^{345}$ RTFO, above n 147, Article 13.4

346 Renewable Fuels Agency. Carbon and sustainability reporting within the Renewable Transport Fuel Obligation - Technical Guidance (2011), Part one.

${ }^{347}$ Ibid, Part two.

348 Zarrilli, above n 92, 9.

${ }^{349}$ Mineral Oil Taxation Law , above n 154, Steenblick, above n 155, 35-36.
} 
- The use of renewable fuels in the United States is governed by the Energy Independence and Security Act 2007 (EISA), which was created with the purpose of increasing energy efficiency and independence, but also addresses greenhouse gas emissions and sustainability issues. ${ }^{350}$ The EISA requires a minimum annual level of renewable fuels use in transportation fuel. The definition of "renewable fuel” in the EISA includes factors on reduction of greenhouse gas emissions, and different types of biofuels are categorised according to their greenhouse gas emission savings. ${ }^{351}$

The aims of the UNFCCC strongly relate to the aim of biofuels certification schemes to reduce greenhouse gas emissions, and it can be considered as relevant to these schemes. Given that the UNFCCC is referenced in some certification schemes, we can say that the regulations in these certification schemes are founded on and supported by the UNFCCC.

There is no international agreement relating to the calculation of greenhouse gas emission savings from biofuel production and use, and no internationally agreed methodology for the calculation. However, the scope of the UNFCCC and Kyoto Protocol would cover the development, and agreement by Parties, of such methodology. The Subsidiary Body for Scientific and Technological Advice (SBSTA) undertakes work on methodological and scientific matters relating to the UNFCCC and the Kyoto Protocol, and would be a competent body to develop international standards for calculating greenhouse gas emissions from biofuels. Some of the work of the SBSTA has included the calculation of emissions from international aviation and maritime transport and methodological issues relating to policy approaches to reducing emissions from deforestation and forest degradation in developing countries. ${ }^{352}$ The use of consistent and internationally agreed methodology for calculating greenhouse gas emission savings would go a long way in ensuring that the related criteria of certification schemes do not discriminate between WTO Members. In the event of a dispute, the use of such methodology would provide a defence against claims that the criteria violate the GATT.

The Ramsar Convention provides an internationally agreed definition of wetlands and peatlands, an international list of areas designated as such, and a commitment for the Parties to conserve these areas. Certification schemes that wish to prohibit the conversion of

\footnotetext{
${ }^{350}$ Zarrilli, above n 92. 10-12.

${ }^{351}$ Sissine, above n $165,5$.

${ }^{352}$ UNFCCC. http://unfccc.int/methods_and science/items/2722.php. Accessed 23 June 2011.
} 
wetlands and peatlands for biofuel production can reference this Convention. There is no such internationally agreed definition of “continuously forested areas” (as per RED), nor any international agreement relating to their conservation. This is a potential gap; if a WTO Member wishes to include this criterion in a certification scheme, they should seek international agreement on the definition and commitment by other Members to the protection of such areas.

\section{International agreements relating to conservation of biodiversity}

\section{(a) Convention on Biological Diversity (CBD)}

The UN Convention on Biological Diversity was signed in 1992; it currently has 193 Parties and is open to all WTO Members. ${ }^{353}$ The Convention states as its objective the "conservation of biological diversity, the sustainable use of its components and the fair and equitable sharing of the benefits arising out of the utilization of genetic resources". 354 The Convention recognises the right of States to exploit their own resources, but also identifies the responsibility to ensure that activities do not damage the environment outside of their jurisdiction. ${ }^{355}$ None of the biofuel certification schemes examined refer to the CBD, but the aims align and the CBD is pertinent to biofuels criteria relating to biodiversity, and could be regarded as a relevant international agreement.

The Convention commits Parties to develop strategies, plans and programs for the conservation and sustainable use of biological diversity. ${ }^{356}$ Each Party must identify and monitor components of biological diversity important for conservation, using certain categories, and establish a system of protected areas for the conservation of biological diversity. ${ }^{357}$ Articles 8 and 9 set down the regulations for managing these protected areas. The Convention also commits members to consider the conservation and sustainable use of

\footnotetext{
353 CBD website: http://www.cbd.int/convention/parties/list/. Accessed 20 July 2011.

${ }^{354}$ CBD, above n 60, Article 1. The Convention defines biological diversity as the variability among living organisms from all sources including, inter alia, terrestrial, marine and other aquatic ecosystems and the ecological complexes of which they are part: this includes diversity within species, between species and of ecosystems (Article 2).

${ }^{355}$ Ibid, Article 3.

${ }^{356}$ Ibid, Article 6.

357 Ibid, Articles 7 and 8. The categories are (1) ecosystems and habitats containing high diversity, large numbers of endemic or threatened species, or wilderness; required by migratory species; of social, economic, cultural or scientific importance; or which are representative, unique or associated with key evolutionary or other biological processes; and (2) species and communities which are threatened; wild relatives of domesticated or cultivated species; of medicinal, agricultural or other economic value; or social, scientific or cultural importance; or important for research into the conservation and sustainable use of biological diversity, such as indicator species; and (3) described genomes and genes of social, scientific or economic importance.
} 
biological diversity in national decision making, and to conduct environmental impact assessments where possible on projects that are likely to have an adverse effect on biological diversity, with a view to minimising such effects. ${ }^{358}$ Article 25 establishes a Subsidiary Body for the provision of scientific and technical advice on the status of biological diversity and the effects of measures taken in accordance with the Convention. As with the UNFCCC, the CBD has appropriate mechanisms and expertise for setting standards, and given its openness to all WTO Members, it is likely to be considered an international body by the TBT Committee.

The development of strategies, plans and programs (as per Article 6) are implemented through National Biodiversity Strategies and Action Plans (NBSAPs), which have been developed by 173 Parties. ${ }^{359}$ The Parties have additionally developed a Strategic Plan for Biodiversity, which takes a strategic approach to implementing the Convention. The Plan sets “Aichi Biodiversity Targets” which are to be used as a framework for developing national and regional targets and the NBSAPs. ${ }^{360}$ The Plan recognises that production and consumption patterns, including in the agricultural, forestry and energy sectors, are one of the underlying causes of biodiversity loss, and the need to ensure that biodiversity concerns are mainstreamed throughout government and society, and one of the goals of the plan is to halt such loss of biodiversity. The Aichi Targets that address this goal include: 361

- By 2020, at the latest, incentives, including subsidies, harmful to biodiversity are eliminated, phased out or reformed in order to minimize or avoid negative impacts, and positive incentives for the conservation and sustainable use of biodiversity are developed and applied, consistent and in harmony with the Convention and other relevant international obligations, taking into account national socio economic conditions (Target 3).

- By 2020, at the latest, Governments, business and stakeholders at all levels have taken steps to achieve or have implemented plans for sustainable production and consumption and have kept the impacts of use of natural resources well within safe ecological limits (Target 4).

\footnotetext{
${ }^{358}$ Ibid, Articles 10 and 14.

${ }^{359}$ CBD website: http://www.cbd.int/nbsap/. Accessed 20 July 2011.

360 agreed by the 193 signatories to the CBD at the COP10 in Nagoya, Aichi Prefecture, Japan in October 2010

361 The Conference of the Parties 10, Decision X/2 Strategic Plan for Biodiversity 2011-2020. UNEP/CBD/COP/10/27/Add.1
} 
- By 2020, the rate of loss of all natural habitats, including forests, is at least halved and where feasible brought close to zero, and degradation and fragmentation is significantly reduced (Target 5).

- By 2020, at least 17 per cent of terrestrial and inland water areas, and 10 per cent of coastal and marine areas, especially areas of particular importance for biodiversity and ecosystem services, are conserved through effectively and equitably managed, ecologically representative and well connected systems of protected areas and other effective area-based conservation measures, and integrated into the wider landscapes and seascapes (Target 11).

\section{(b) Other sources of international guidance on biodiversity preservation}

As noted in section 1(b), the Ramsar Convention outlines the value of wetlands in maintaining biodiversity and habitat for endangered species. It provides a definition of wetlands and a List of Wetlands of International Importance for which Parties are required to protect.

The Global Forest Resources Assessment (GFRA), coordinated by the UN Food and Agriculture Organization (FAO), monitors the world's forests and recognises forest biological diversity as one of the thematic elements of sustainable forest management. ${ }^{362}$ As noted earlier in this chapter, the FAO is recognised as an international standard setting body by the WTO. The definition of primary forest used by the GFRA is "forest of native species where there are no clearly visible indications of human activities and the ecological processes have not been significantly disturbed", 363 and this definition is referenced by the RED in its criterion prohibiting the use of highly biodiverse land for biofuel production. Although the GFRA is useful in providing definitions of primary forests and other forested land, and in outlining the forested areas designated for the conservation of biological diversity, it does not confer any obligation on countries to protect areas of high biodiversity. Similarly, the International Union for the Conservation of Nature also provides lists of protected areas or species, and is referenced in the RED.

\footnotetext{
${ }^{362}$ GFRA website: http://www.fao.org/forestry/fra/en/. Accessed 20 July 2011.

${ }^{363}$ Food and Agriculture Organization of the UN. Global Forest Resources Assessment 2010. FAO Forestry Paper 163, 50.
} 
(c) Applicability to biofuels certification criteria

Several schemes cite the protection of biodiversity as one of the requirements for gaining certification for biofuels.

- The RED recognises that the increasing demand for biofuels could have the effect of encouraging destruction of biodiverse lands, and therefore criteria to ensure the preservation of such lands is needed to ensure the protection of rare, threatened or endangered species. It specifies that biofuels should not be made from feedstocks obtained from land with high biodiversity value. It references the definition of primary forest used by the Food and Agriculture Organisation of the United Nations (FAO) in its Global Forest Resource Assessment, and also recognises the value of biodiverse grasslands. ${ }^{364}$

- The German Biofuel Ordinance aims to ensure that biofuels are produced in a way that does not have undesirable impacts on natural systems or biodiversity. ${ }^{365}$ The requirements relating to the preservation of biodiverse land are the same as those set out in the RED and outlined in the section above. ${ }^{366}$

- The UK RTFO takes into consideration the sustainability risk of biofuels, including the risks to the conservation of biodiversity. Suppliers of biofuels into the UK must report on the area in which the feedstock was produced, and the biodiversity values and environmental sensitivities associated with that area are assessed by the RFA. ${ }^{367}$

- The amended Swiss Mineral Oil Taxation Law specifically states that biofuels must not damage the environment in ways that are greater than the environmental damage caused by gasoline, they must not damage tropical forest or endanger biodiversity. ${ }^{368}$ Biofuels produced from palm oil, soybeans and grains are considered not to meet the requirements. ${ }^{369}$

- The definition of "renewable fuel" in the Energy Independence and Security Act 2007 (EISA) includes factors, not just on the types of feedstock used but also the

\footnotetext{
${ }^{364}$ RED, above n 128, paragraph 69.

365 TBT Committee, above n 136.

${ }^{366}$ Bioliquids Ordinance, above n 137, Article 4.

${ }^{367}$ RFA, above n 346, 19-20.

${ }^{368}$ Mineral Oil Taxation Law, above n 154, Article 19b; Steenblick, above n 155, 35-38.

${ }^{369}$ Mineral Oil Taxation Law, above n 154, Article 19b; Steenblick, above n 155, 36.
} 
land that renewable fuel feedstocks come from. ${ }^{370}$ Although the EISA - unlike other certification schemes - does not contain regulations regarding land of high biodiversity value, one of the purposes of the land use restrictions is to prevent the loss of biodiversity. ${ }^{371}$

Currently, biofuel certification schemes contain criteria that land of high biodiversity value should not be used for biofuel feedstock production, but not all schemes provide a definition of high biodiversity. Although the Convention on Biological Diversity does not contain requirements regarding biofuel production, it does provide an internationally agreed way of identifying areas of high biodiversity and places an obligation on Parties to protect them. Certification criteria relating to biodiversity conservation should reference the CBD, as this is the most relevant international agreement. The Convention and its implementation strategies provide a way to define and categorise areas of high biodiversity, set targets for their conservation and place responsibility on Parties to develop national plans to meet the targets. The Subsidiary Body could be tasked with developing a standard for assessing the status of biological diversity of an area. A biofuels certification criteria that aims to protect biodiversity from expanding production could adopt this standard reference the Convention and include a specification that biofuels are only to be eligible for tax relief or a quota if the country of production has developed a national plan for the protection of biodiversity, is on track to meet the Aichi targets, and that the production of feedstock for biofuels does not compromise the ability of the country to meet the targets. In addition, future revisions of the Aichi Targets could include a target specifically relating to identifying areas of high biodiversity value that are not to be used for biofuel feedstock (or other agricultural) production.

An internationally agreed methodology, possibly developed by the Subsidiary Body, for assessing the biodiversity value of land would support the biodiversity-related criteria of certification schemes and would ensure that these criteria do not discriminate between WTO Members.

\footnotetext{
${ }^{370}$ Environmental Protection Agency. Regulation of Fuels and Fuel Additives: Changes to Renewable Fuels Standard Program; Final Rule (2010) 75(58) Federal Register, 14691.

${ }^{371}$ Ibid, 14692.
} 
Potential environmental problems associated with biofuel production fall into two categories. Some environmental concerns, for example those relating to soil quality and erosion, are likely to be confined within the national boundaries of the country in which they occur. Other environmental concerns, for example those relating to pollution of water and air could be transboundary in nature.

For the first type of environmental concern, the certification schemes described above cite compliance with national or regional environmental laws and regulations. There is no international agreement to regulate such environmental concerns, and it is appropriate that they are addressed domestically. International guidance is available in some situations. For example, the Millennium Ecosystem Assessment (MEA) monitors the consequences of ecosystem change for human well-being, and assesses the scientific basis for action needed to enhance the conservation and sustainable use of those systems and their contribution to human well-being. ${ }^{372}$ Although the MEA is a good source of advice on determining how a change in land use may affect the ecosystem services and environment of an area, it does not constitute an agreement between countries to ensure environmental sustainability.

Environmental concerns relating to the pollution of water and air could be transboundary in nature. In the context of biofuel production, this type of pollution is most likely to result from the use of chemicals such as pesticides and herbicides in the production of the feedstock (although not specifically mentioned by certification schemes), or increased pollution as the result of land clearing through burning. Transboundary pollution is referenced in the Declaration of the United Nations Conference on the Human Environment and the Rio declaration on Environment and Development, and also addressed by the Stockholm Convention on Persistent Organic Pollutants.

(a) Declaration of the United Nations Conference on the Human Environment

This document is a principles-based declaration, and does not place obligations on Parties other than recognition of the importance of preservation of the human environment. It does not set international standards, but provides some guidance on the environmental principles that are broadly accepted internationally.

${ }^{372}$ MEA website: http://www.maweb.org/en/About.aspx. Accessed 20 July 2011. 
Principle 2 states that: ${ }^{373}$

The natural resources of the earth, including the air, water, land, flora and fauna and especially representative samples of natural ecosystems, must be safeguarded for the benefit of present and future generations through careful planning or management, as appropriate.

The declaration asserts that States have the right to exploit their own resources and set their own environmental policies, but also have a responsibility to ensure that activities within their jurisdiction do not cause environmental damage beyond the limits of their national jurisdiction. ${ }^{374}$

\section{(b) Rio Declaration on Environment and Development}

The Rio Declaration is also a principles-based declaration, not an international agreement or international standard. As with the UN Declaration, it conveys the same right for States to exploit their own resources, and the same responsibility to ensure that activities do not cause environmental damage beyond their national jurisdiction. ${ }^{375}$ Principle 12 deals with trade policy measures, stating measures to address transboundary environmental problems should not constitute arbitrary or unjustifiable discrimination or a disguised restriction on international trade, and should be based on international consensus as far as possible. It also states that unilateral actions to deal with environmental challenges outside the jurisdiction of the importing country should be avoided.

Other aspects of the Rio Declaration include the principle that States should reduce and eliminate unsustainable patterns of production, the promotion of international cooperation in protecting and restoring ecosystems and addressing environmental problems, while recognising differentiated responsibilities of developed and developing countries. ${ }^{376}$ It advocates the use of environmental impact assessments for proposed activities that are likely to have a significant adverse affect on the environment. ${ }^{377}$

\section{(c) Stockholm Convention}

The Stockholm Convention entered into force in 2004 and was amended in 2009, and it is open to all States. Its stated objective is to protect human health and the environment from

\footnotetext{
${ }^{373}$ Declaration of the United Nations Conference on the Human Environment (1972), Principle 2.

${ }^{374}$ Ibid, Principle 21.

${ }^{375}$ Rio Declaration on Environment and Development (1992), Principle 2.

${ }^{376}$ Ibid, Principles 7, 8 and 12.

${ }^{377}$ Ibid, Principle 17.
} 
persistent organic pollutants. ${ }^{378}$ The persistent organic pollutants are chemicals that are likely, from long-range transport, to have significant adverse effects on human health and environment. The pollutants include some pesticides and insecticides used in agricultural production, and that also could be used in biofuel feedstock production. The Convention recognises that such pollutants can be transported, through air, water and migratory species, across international boundaries and be deposited far from their place of release. The Convention contains lists of chemicals that are to be prohibited (Annex A), or restricted to certain purposes or uses (Annex B). It places responsibility on Parties to reduce the unintentional release, from anthropogenic sources, of listed chemicals into the environment.

\section{(d) Applicability to biofuels certification criteria}

Some certification schemes include criteria relating to environmental concerns such as water quality, soil degradation and pollution.

- The European RED states that, where biofuels are made from feedstocks produced from within the European Union (EU), their production must comply with environmental requirements for agriculture including those concerning the protection of groundwater and surface water quality. ${ }^{379}$ Similarly, the German Biofuel Ordinance specifies the regulations with which farmers from within the EU must comply. ${ }^{380}$ There is no similar requirement for biofuels made from feedstocks produced outside the EU; however the RED encourages the development of multilateral and bilateral agreements that cover environmental concerns. In the absence of such agreements, the RED requires reporting on environmental issues. The RED references the Millennium Ecosystem Assessment for data on the conservation of ecosystem services such as watershed protection and erosion control. ${ }^{381}$

- The RTFO takes into consideration the environmental sustainability of biofuel production, including soil conservation, sustainable water use and air quality. Suppliers of biofuels must report on the area in which the feedstock was produced, and the environmental sensitivities associated with that area are assessed by the RFA. $^{382}$

\footnotetext{
${ }^{378}$ Stockholm Convention on Persistent Organic Pollutants (2009), Article 1.

${ }^{379}$ RED, above n 128, paragraph 74.

${ }^{380}$ Bioliquids Ordinance, above n 137, Article 7.

${ }^{381}$ RED, above n 128, paragraphs 74 and 77.

${ }^{382}$ RFA, above n 346, 19-20.
} 
Environmental concerns that have only a local impact can be addressed domestically, rather than through international environmental agreements. Some certification schemes require compliance with domestic environmental laws, and this would be an appropriate way to address such concerns. Certification schemes that contain more specific criteria relating to local environmental concerns are not likely to be WTO compliant.

Environmental concerns arising from the transboundary movement of chemicals are covered in the Stockholm Convention. The Annexes of the Stockholm Convention should be examined to ensure that all chemicals of concern in biofuel production are covered. Certification criteria could cite the need to comply with this Convention, and also reference the principles in the Rio Declaration and the Declaration of the UN Conference on the Human Environment.

\section{$4 \quad$ Food security}

The only certification scheme, of those examined in detail, which attempts to regulate the impact of biofuel production on food security is the European RED. This scheme does not contain particular criteria related to food security, but rather requires monitoring and reporting on the impact of biofuel production on food production and food prices, particularly in developing countries. ${ }^{383}$

Food security is a broad issue, and many factors in addition to biofuel production contribute to food availability and affordability. Although the impact of biofuel production on food security is a clear public concern, it would be difficult for any one government or organization to effectively address the issue through certification criteria. This may be the reason for the lack of criteria in certification schemes relating to food security.

One possible criterion could be to restrict biofuels (qualifying for financial or other incentives) to those produced from non-food feedstocks, or produced on land that is not suitable for food production. However, this does not consider that some biofuels produced from food crops, or in certain locations, may not have any impact on food security, and such a criterion could be considered to be trade restrictive. A highly prescriptive criterion such as this may also stifle innovation in both the biofuel and food sectors, and unnecessarily disadvantage developing countries.

\footnotetext{
${ }^{383}$ RED, above n 128 , Article 17.7
} 
Certification schemes could address the issue by citing the need to monitor and report on the impact of policy on food security, and encourage international collaboration on the issue. If an international agreement relating to food security is developed, this is likely to reference biofuel production and could be picked up by individual certification schemes.

\section{$5 \quad$ International agreements relating to labour and social conditions}

\section{(a) International Labour Organization (ILO)}

The ILO is the organisation responsible for developing international labour standards. It is a tripartite organisation that brings together governments, employers and workers to ensure policies and programs promote decent work standards.

\section{(b) General issues}

One of the concerns regarding increased biofuel production is that producers of feedstock or manufacturers may employ people under unacceptable working conditions or may not respect land-use rights or other human rights. Some certification schemes, for example the RED and the Swiss Mineral Oil Taxation Law, contain criteria to ensure acceptable working conditions and respect of human rights.

The amended Swiss Mineral Oil Taxation Law states that biofuels must be produced under socially acceptable conditions, citing the ILO and requiring compliance with domestic social legislation in the country of production.

Although the Conventions of the ILO may be applicable to working conditions associated with biofuel production, there is some doubt as to whether reference to labour or social conditions should be included in certification schemes at all. The WTO has actively discouraged linkages between trade conditions and social standards. For example, at the WTO Ministerial Conference in Singapore in 1996, Members agreed that market access should not be linked with labour standards. ${ }^{384}$ Unlike environmental or human health concerns, social concerns are not mentioned in WTO Agreements, as discussed in Chapter IV.

Certification schemes could encourage compliance with ILO standards or other internationally agreed standards, and could require reporting on labour and social conditions. However, any criterion that specifies that a standard must be met is unlikely to be compliant with the relevant WTO Agreements, even if that standard is internationally accepted.

${ }^{384}$ Zarrilli, above n 92, 35. 


\section{Conclusions}

This chapter has explored the relevancy of international agreements to biofuel certification schemes. The analysis has highlighted that some international agreements could be used to develop relevant international standards on which certification could be based, and has come to the following conclusions:

- For criteria relating to greenhouse gas savings, the UNFCCC and Kyoto Protocol are relevant overarching international agreements, although they do not specifically cover biofuel production. The Subsidiary Body for Scientific and Technological Advice could be tasked with the development of internationally agreed methodology for calculating the greenhouse gas emission saving from biofuel production and use, which could then form an international standard. The Ramsar Convention provides an internationally agreed definition of wetlands and peatlands, an international list of areas designated as such, and a commitment for the Parties to conserve these areas. It could be referenced by certification schemes aiming to protect wetlands and peatlands from biofuel feedstock production. There is no such international standard for protecting continuously forested areas.

- For criteria relating to biodiversity, the Convention on Biological Diversity could provide an internationally agreed way of identifying areas of high biodiversity and place an obligation on Parties to protect them. An international standard to describe areas of high biodiversity value could be developed by the Subsidiary Body. Certification criteria relating to biodiversity conservation could reference the CBD, as this is the most relevant international agreement.

- Environmental concerns that have only a local impact can be addressed domestically, rather than through international environmental agreements. Environmental concerns arising from the transboundary movement of chemicals is covered in the Stockholm Convention. Certification criteria could cite the need to comply with this Convention, and also reference the principles in the Rio Declaration and the Declaration of the UN Conference on the Human Environment.

- Food security is a difficult issue to address through certification. It is a broad issue that needs to be addressed on a global scale through international coordination and agreement. Certification schemes could address the issue by citing the need to 
monitor and report on the impact of biofuels policies on food security, and encourage international collaboration on the issue.

- The ILO has drafted international standards that relate to labour and social conditions. However, the WTO has actively discouraged linkages between trade conditions and social standards. Certification schemes could encourage compliance with ILO standards, but criteria specifying that a standard must be met is unlikely to be compliant with the relevant WTO Agreements.

Previous chapters have identified a lack of consistency and international coordination between the various biofuels certification schemes, and have argued that better international coordination, especially through the development and use of international standards, is needed to ensure the WTO compliance of certification schemes. Any effort towards greater harmonisation and the development of international standards relating to the sustainable development of biofuels would assist in negotiations within the WTO to have biofuels classified as an "environmental good". Traded biofuels, so long as their environmental benefits are assured through certification, could then benefit from greater tariff reduction than average, further promoting their production and use. If certified biofuels were classified as environmental goods, this would encourage the uptake of certification schemes also support any argument that certification provides a legitimate point of differentiation between the biofuel products.

This chapter has identified some existing international agreements that could be relevant, and international bodies that are appropriate and capable of developing specific international standards that would support biofuels certification. In particular, standards relating to the calculation of greenhouse gas emissions from biofuels production and standards relating to the assessment of biological diversity could be developed by technical bodies under the UNFCCC and the CBD. There are some biofuels certification criteria for which international standards could not be developed under the umbrella of existing agreements. For example, food security concerns are not addressed by any existing agreement. If this issue is to be addressed, a new international agreement would need to be developed, either specifically for biofuel production more generally for factors influencing global food security. Given the time that would be needed to negotiate a new agreement, biofuels certification schemes - as an interim step - could encourage monitoring and reporting of the impact of biofuel production on food security. 


\section{CONCLUSIONS}

The use of biofuels as a renewable energy source has been promoted as a promising tool for combating climate change, as it could result in a significant reduction of greenhouse gas emissions. Biofuels have the potential to be used to service the major energy sectors of heat, electricity and transport fuels, and therefore are a good way to diversify energy supply and reduce the traditional reliance on oil for energy. This increased emphasis on protecting the environment together with price rises of fossil fuels has stimulated many countries to promote the use of alternative fuels. As a result, production and trade volumes are growing rapidly, with little initial consideration of whether biofuels are delivering the intended benefits in terms of greenhouse gas emission savings, or consideration of the impacts that biofuels have on the environment, food production or social conditions. In particular, there is uncertainty as to which feedstocks and growing areas will have the greatest impact on greenhouse gas emissions. Some first generation biofuels are inefficient to produce and their production and use may result in greater emissions than if fossil fuel had been used.

Certification is a key tool that has been developed by governments and nongovernment organisations as a way to ensure that biofuels provide the desired benefits, with minimal environmental or social impact/damage. The schemes have mostly been developed independently, with different criteria put in place by various national governments and organisations. Better international coordination is needed to avoid the proliferation of standards and to provide a clearer direction in the approach to be taken, particularly with the methodology used to measure greenhouse gas emissions. ${ }^{385}$ Developing countries may have limited capacity to comply with a large and growing number of sustainability criteria which are country-specific. ${ }^{386}$ Certification schemes are just one part of biofuel policies that have been developed by governments. Other policies, such as research and development or other support measures, may be integral to meeting the goal of reducing greenhouse gas emissions through the use of biofuels. Although this dissertation has not examined other policies in detail, it is clear that in some cases consistency between policies is lacking. Experts have suggested that policy support packages should take an integrated approach. Subsidies and support of inefficient biofuels should be removed, and research and development for second

\footnotetext{
${ }^{385}$ For example see Mol, above n 39, 71; Dufey, above n 6, 52; van Dam, above n 33, 749.

${ }^{386}$ Zarrilli, above n 92, 29-30.
} 
generation biofuels should be part of a comprehensive strategy. It is encouraging that many governments are beginning to invest in second generation technologies, however the value of some first generation biofuels should not be discounted, as some feedstocks and production methods are very efficient. A consistent and robust methodology for measuring the greenhouse gas savings associated with different biofuel feedstocks and production areas could ensure that both certification schemes and other policy measures are effective in encouraging the most beneficial biofuels.

There are several concerns regarding the consistency of certification schemes with WTO Agreements., These concerns need to be addressed, particularly as certifications schemes will come under increasing scrutiny as biofuel production and trade grows. Certification schemes developed to address the sustainability of biofuels production could constitute an artificial barrier to international trade. Analysis of the WTO-consistency of biofuels certification has highlighted two areas that could be problematic.

A member country may apply tariffs or border taxes that discriminate between different biofuels based on whether their methods of production are harmful to people or to the environment. There is considerable debate about whether production methods can be taken into account when differentiating between two products for the purpose of market access or the application of taxes and tariffs. If biofuels cannot be certified based on manufacturing processes, then governments aiming to promote sustainable biofuel use would not be able to apply tax or tariff concessions to biofuels produced in a manner that reduces greenhouse gas emissions. There is little clear guidance from the WTO on this matter; however the history of dispute findings would suggest that the differentiation of biofuels based on the sustainability of their production would not necessarily be consistent with WTO rules.

Certification could be seen as more trade restrictive than necessary to fulfil the legitimate objective. The objective of a biofuels certification scheme - for the purpose of the TBT Agreement - is likely to be presented as the protection of human health or safety, animal or plant life or health, or the environment. Although Members clearly have the right to impose trade measures to protect the environment within their own borders, it is not clear if they can impose measures with the purpose of protecting the environment in another country, or on a global scale. Transboundary environmental measures have been upheld in one 
previous dispute case. ${ }^{387}$ However, the measures were supported by reference to international agreements that allowed Members to take actions to protect animals, whether they are located within or outside their jurisdiction. In the absence of an international standard for biofuels production, certification regulations may be challengeable as inconsistent with the TBT Agreement or the GATT. There is a clear need for the countries and organisations involved in biofuel production to determine ways to encourage the harmonisation of biofuel certification schemes and support policies to form a legally founded and globally accepted arrangement.

One way to ensure that a certification scheme is compliant is to align the criteria with internationally agreed standards. For some of the common criteria used in certification schemes, such as those relating to protection of biodiversity, there are international agreements or standards that can be used as a basis for the criteria. International bodies that have been established to develop international standards or agreements could also be tasked with developing appropriate and internationally agreed methodologies against which certification criteria could be measured. The use of these international standards and bodies would be a good short-term step to improve international coordination of biofuels certification, and to improve their consistency with the WTO agreement.

Of most importance in this area is the development of an internationally agreed methodology for measuring the greenhouse gas savings associated with different types of biofuel production. Not only would standard methodology help to ensure that the policy goal is being met, it would also ensure that trade measures relating to greenhouse gas emissions are not discriminatory. Currently, some certification schemes favour the use of certain biofuel types or feedstocks over others, due to the methods used to determine greenhouse gas savings. However, without international discussion on the most appropriate methodology, there is a risk that the biofuels that are most efficient to produce in a given region may be disadvantaged. The methodology may also not take into account any new technologies that are developed for different - and most likely more efficient - feedstocks, and may inadvertently discriminate against second generation biofuels.

There is scope under the UNFCCC and Kyoto Protocol to develop, and gain agreement by Parties, of consistent methodology. The Subsidiary Body for Scientific and Technological Advice could be tasked with its development, possibly with advice from the Intergovernmental Panel on Climate Change. Some countries have suggested that biofuels be

${ }^{387}$ US - Import Prohibition of Certain Shrimp and Shrimp Products, above n 246, para 7.45. 
classified as “environmental goods" under the Harmonized System. The development of methodology to calculate greenhouse gas savings would assist in determining which biofuels would be environmentally beneficial, and in gaining agreement that these biofuels be classified as environmental goods. This classification would help in demonstrating that certified and uncertified biofuels are not "like" products, and therefore assist certification schemes in being compliant with WTO Agreements.

A similar short-term solution could be employed to standardise the criteria relating to the conservation of biodiversity. Existing international agreements, such as the Convention on Biological Diversity, provide a way to define and categorise areas of high biodiversity, set targets for their conservation and place responsibility on Parties to develop national plans to meet the targets. The CBD has a Subsidiary Body that could develop a standard for assessing the status of biological diversity of an area. A biofuels certification scheme that bases its criteria for biodiversity conservation on this standard would ensure that these criteria do not discriminate between WTO Members.

In the longer term, international coordination of biofuels policies could be achieved through the development of a new international standard for sustainable biofuel production. A biofuel standard could cover the sustainability criteria that are not currently addressed by any international agreement. Biofuel certification measures that aim to protect the environment or human health in the area of production would be supported by a new standard, if there were a relationship between the design of the measure and the policy goal, and it is applied in a way that is not arbitrary or discriminatory. A new agreement could also address the broader issues associated with biofuel production, such as the risk to food security. However, the issue of food security is affected by many factors in addition to biofuel production, and the broader context needs to be acknowledged and addressed. Given the time that would be needed to negotiate a new agreement, biofuels certification schemes as an interim step - could encourage monitoring and reporting of the impact of biofuel production on food security, human health and the environment, while also requiring compliance with existing international environmental agreements and standards relating to greenhouse gas emissions and biodiversity, as they are developed. 


\section{BIBLIOGRAPHY}

\section{Agreements and treaties}

Agreement on Technical Barriers to Trade (15 April 1994).

Agreement on the Application of Sanitary and Phytosanitary Measures (15 April 1994).

Convention on Biological Diversity (1992).

Declaration of the United Nations Conference on the Human Environment (1972).

General Agreement on Tariffs and Trade (15 April 1994).

Kyoto Protocol to the United Nations Framework Convention on Climate Change (1998).

Marrakesh Protocol to the General Agreement on Tariffs and Trade 1994 (15 April 1994).

Ramsar Convention on Wetlands on International Importance Especially as Waterfowl Habitat (1987).

Rio Declaration on Environment and Development (1992).

Stockholm Convention on Persistent Organic Pollutants (2009).

United Nations Framework Convention on Climate Change (1992).

\section{Dispute resolution}

Brazil - Measures Affecting Desiccated Coconut (21 February 1997) WT/DS22/AB/R (Appellate Body, WTO).

Brazil - Measures Affecting Imports of Retreaded Tyres (12 June 2007). WT/DS332/R (Panel Report, WTO).

European Communities - Measures Affecting Asbestos and Asbestos-Containing Products (12 March 2001) WT/DS135/AB/R (Appellate Body, WTO).

European Communities - Measures Affecting Asbestos and Asbestos-Containing Products (18 September 2000) WT/DS135/R (Panel Report, WTO).

European Communities - Measures Affecting the Approval and Marketing of Biotech Products (29 September 2006) WT/DS291/R (Panel Report, WTO).

Japan - Tariff on Imports of Spruce, Pine, Fir (SPF) Dimension Lumber (19 July 1989). L/6470 - 36S/167 (Panel Report, WTO).

Japan - Taxes on Alcoholic Beverages (4 October 1996) WT/DS8/AB/R (Appellate Body, WTO).

Spain - Tariff Treatment of Unroasted Coffee (11 June 1981). L/5135 - 28S/102 (Panel Report, WTO). 
Thailand - Customs and Fiscal Measures on Cigarettes from the Philippines (17 June 2011) WT/DS371/AB/R (Appellate Body, WTO)

United States - Measures Affecting the Cross-Border Supply of Gambling and Betting Services (7 April 2005) WT/DS285/AB/R (Appellate Body, WTO).

United States - Restrictions on Imports of Tuna (3 September 1991). DS21/R - 39S/155 (Panel Report, WTO).

United States - Standards for Reformulated and Conventional Gasoline (29 January 1996). WT/DS2/AB/R (Appellate Body, WTO).

United States - Standards for Reformulated and Conventional Gasoline (29 January 1996). WT/DS2/R (Panel Report, WTO).

US - Import Prohibition of Certain Shrimp and Shrimp Products (12 October 1998) WT/DS58/AB/R (Appellate Body, WTO).

US - Import Prohibition of Certain Shrimp and Shrimp Products (15 May 1998) WT/DS58/R (Panel Report, WTO).

\section{Legislation}

Directive 2003/30/EC of the European Parliament and of the Council on the promotion of the use of biofuels or other renewable fuels for transport, 8 May 2003.

Directive 2003/96/EC of the European Parliament and of the Council restructuring the Community framework for the taxation of energy products and electricity, 27 October 2003.

Directive 2009/30/EC of the European Parliament and of the Council amending Directive 98/70/EC as regards the specification of petrol, diesel and gas-oil and introducing a mechanism to monitor and reduce greenhouse gas emissions and amending Council Directive 1999/32/EC as regards the specification of fuel used by inland waterway vessels and repealing Directive 93/12/EEC, 23 April 2009.

Directive 2009/28/EC of the European Parliament and of the Council on the promotion of the use of energy from renewable sources and amending and subsequently repealing Directives 2001/77/EC and 2003/30/EC, 23 April 2009.

Ordinance on requirements pertaining to sustainable production of bioliquids for electricity productions (Germany; Biomassestrom-Nachhaltigkeitsverordnung (BioSt-NachV)), 15 December 2008.

Ordinance on requirements pertaining to sustainable production of biofuels (Germany; Biokraftstoff-Nachhaltigkeitsverordnung - BiokraftNachV), December 2009.

The Renewable Transport Fuels Obligations Order 2007 (UK). Transport Energy Sustainable and Renewable Fuels 2007. 


\section{WTO material}

Decision on Trade and Environment (WTO). Adopted by ministers at the meeting of the Uruguay Round Table Negotiations Committee in Marrakesh, 14 April 1994.

GATT Report of the Working Party Border Tax Adjustment (World Trade Organization BISD 18S/97, 2 December 1970).

Germany - Notification to the Committee on Technical Barriers to Trade (World Trade Organization G/TBT/N/DEU/10, 30 October 2009).

Germany - Notification to the Committee on Technical Barriers to Trade (World Trade Organization G/TBT/N/DEU/9, 15 July 2009).

WTO Committee on Trade and Environment, CTE Report of the Meeting Held on 3 November 2008 (World Trade Oganization WT/CTE/M/46 12 January 2009).

WTO Committee on Trade and Environment, Report of the Meeting Held on 10 July 2009 (World Trade Oganization WT/CTE/M/47 31 August 2009).

\section{Journal articles}

Ansari, Abdul Haseeb, “GATT/WTO and MEAs: Resolving the competing paradigm” (2007) 6(2) Journal of International Trade Law \& Policy 2-13.

Banse, Martin, Hans van Meijl, Andrezej Tabeau and Geert Woltjer, "Will EU biofuel policies affect global agricultural markets?” (2008) 35(2) European Review of Agricultural Economics 117-141.

Bernstein, Steven, and Erin Hannah, "Non-state global standard setting and the WTO: Legitimacy and the need for regulatory space" (2008) 11(3) Journal of International Economic Law 575-608.

Bluemel, Erik, "Biomass energy: ensuring sustainability through conditioned economic incentives” (2007) 19 Geo. Int'l Envtl. L. Rev. 673-697.

Condon, Bradly, “Climate change and unresolved issues in WTO law” (2009) 12 J. Int'l Econ. L., 895-926.

Burleson, Elizabeth, “A Climate of extremes: Transboundary conflict resolution” (2008) 32 Vt. L. Rev. 477-523

Cai, Phoenix X.F., "Think big and ignore the law: U.S corn and ethanol subsidies and WTO law” (2009) 40 Geo. J. Int'l L. 865-917.

Christian, Kelly, “Worth keeping around? The United States' biofuel policies and compliance with the World Trade Organization” (2009) 38 Ga. J. Int'l \& Comp. L. 165-204. 
de Lima Mantilla, Yuri, "The survival of the United States ethanol subsidies and tariff: Are there further reasons to keep them on the books?” (2008) 15 ILSA J. Int'l \& Comp. L. 203225.

Endres, Jody M., "Clearing the air: The meta-standard approach to ensuring biofuels environmental and social sustainability” (2010) 28 Va Envtl.L. J. 73-120.

Faaij, Andre, "Developments in international bio-energy markets and trade” (2008) 32 Biomass and Bioenergy 657-659.

Frow, Emma, David Ingram, Wayne Powell, Deryck Steer, Johannes Vogel and Steven Yearly, "The politics of plants.” (2009) 1 Food Sec., 17-23.

Government of the United Kingdom, “The Government's response to the house of commons Environmental Audit Committee’s report 'Are biofuels sustainable?’” (2008) 1 J. P. L. 1268.

Hoogwijk, M., A. Faaij, R. van den Broek, G. Berndes, D. Gielen, and W. Turkenburg, "Exploration of the ranges of the global potential of biomass for energy" (2003) 25 Biomass and Bioenergy 119.

Junginger, Martin, Torjus Borkesjo, Douglas Bradley, Paulo Dolzan, Andre Faaij, Jussi Heinimo, Bo Hektor, Oyvind Leistad, Erik Ling, Miles Perry, Erik Piacente, Frank RosilloCalle, Yves Ryckmans, Peter-Paul Schouwenberg, Birger Solberg, Erik Tromborg, Arnaldo da Silva Walter and Marc de Wit, "Developments in international bioenergy trade” (2008) 32 Biomass and Bioenergy 717-729.

Kapoor, Abhinay "Product and process methods (PPMs): 'a losing battle for developing countries’” (2011) 17(4) International Trade Law \& Regulation.

Ketabi, Noushin, "The blood of going green: using environmental initiatives to account for the human rights violations of the green movement” (2009) 32 Fordham Int'l L.J. 1911-1946.

Koning, Niek and Arthur Mol, "Wanted: institutions for balancing global food and energy markets (2009) 1 Food Sec. 291-303.

Kurz, Natalie Jean, “Corn ethanol: setting straight a misguided attempt to free the United States from foreign oil” (2009) 31 Hous. J. Int'l L. 377-417.

Loppacher, Laura, “The conflicting international trade law governing products of biotechnology: the case of biofuels” (2005) 2 J.I.B.L. 54-61.

Marceau, Gabrielle, and Joel P. Trachtman "The Technical Barriers to Trade Agreement, the Sanitary and Phytosanitary Measures Agreement, and the General Agreement on Tariffs and Trade. A Map of the World Trade Organization Law of Domestic Regulation of Goods" (2002) 36(5) Journal of World Trade, 811-881. 
McCarl, Bruce, and Fred Boadu, "Bioenergy and U.S. renewable fuels standards: law, economic, policy/climate change and implementation concerns.” (2009) 14 Drake J. Agric. L., 43-73.

McDonald, Jan, "Domestic regulation, international standards, and technical barriers to trade" (2005) 4(2) Journal of World Trade 249-274.

Mol, Arthur, "Boundless Biofuels? Between Environmental Sustainability and Vulnerability" (2007) 47(4) UK Sociologia Ruralis, 297-315.

Mol, Arthur, “Environmental authorities and biofuel controversies” (2010) 19(1) Envt'l Pol., 61-79.

Motaal, Doaa Abdel, “The Biofuels Landscape: Is There a Role for the WTO?” (2008) 42(1) Journal of World Trade, 61-86.

Msangi, Siwa and Mark Rosegrant "Agriculture and the environment: linkages, trade-offs and opportunities” (2007) 19 Geo. Int'l Envtl L. Rev. 709.

Schroder, Humberto Zuniga, "Definition of the concept "international standard" in the TBT Agreement” (2009) 43(6) Journal of World Trade 1223-1254.

Seminerio, Frank, “A tale of two subsidies: how federal support programs for ethanol and biodiesel can be created in order to circumvent fair trade challenges under World Trade Organization rulings” (2008) 26 Penn St. Int'l L. Rev. 963-995.

Smeets, Edward, Martin Junginger, Andre Faaij, Arnaldo Walter, Paulo Dolzan and Wim Turkenburg, "The sustainability of Brazilian ethanol - An assessment of the possibilities of certified production” (2008) 23 Biomass and Bioenergy 781-813.

Switzer, Stephanie, and Joseph McMahon, "EU biofuels policy - raising the question of WTO compatibility” (2010) 26 UCD Working Papers in Law, Criminology and Socio-legal Studies, 1-22.

Thornley, Patricia and Deborah Cooper, "The effectiveness of policy instruments in promoting bioenergy” (2008) 32 Biomass and Bioenergy 903-913.

Turgeon, Evan, "Federal forests, biomass, and ethanol: Energy security sabotaged” (2009) 39 Envtl. L. Rep. News \& Analysis 10140-10151.

van Dam, Jinke, Martin Junginger, Andre’ Faaij, Ingmar Jurgens, Gustavo Best, Uwe Fritsche, "Overview of recent developments in sustainable biomass certification” (2008) 32 Biomass and Bioenergy, 749-780.

Verdonk, M., C. Dieperink and A.P.C. Faaij “Governance of the emerging bio-energy markets” (2007) 35 Energy Policy, 3909-3924. 
Verhaegen, Karolien, Leonardo Meeus and Ronnie Belmans, "Towards an international tradable green certificate system - The challenging example of Belgium” (2009) 13 Renewable and Sustainable Energy Reviews 208-215.

Verhaegen, K, Leonardo Meeus and Ronnie Belmans, “Towards an international tradable green certificate system - The challenging example of Belgium” (2009) 13 Renewable and Sustainable Energy Reviews 208-215.

von Braun, Joachim, “Addressing the food crisis: governance, market functioning, and investment in public goods” (2009) Food Sec. 9-15.

\section{Reports}

Al-Riffai, Perrihan, Betina Dimaranan and David Laborde, Global Trade and Environmental Impact Study of the EU Biofuels Mandate. International Food Policy Research Institute, Washington, 2010.

Bringezu, Stefan, Helmut Schutz, Meghan O’Brien, Lea Kauppi, Robert Howart, Jeff McNealy, Towards Sustainable Production and Use of Resources: Assessing Biofuels. United Nations Environment Programme, 2009.

Commission of the European Communities, Proposal for a Directive of the European Parliament and of the Council amending Directive 98/70/EC as regards the specification of petrol, diesel and gas-oil and introducing a mechanism to monitor and the introduction of a mechanism to monitor and reduce greenhouse gas emissions from the use of road transport fuels and amending Council Directive 1999/32/EC, as regards the specification of fuel used by inland waterway vessels and repealing Directive 93/12/EEC. Brussels, 31.1.2007 $\operatorname{COM}(2007) 18$.

Doornbosch, Richard and Ronald Steenblick, Biofuels: Is the Cure Worse than the Disease? Organisation for Economic Co-operation and Development SG/SD/RT(2007)3/REV1, Paris, 2007.

Dufey, Annie, Biofuels Production, Trade and Sustainable Development: Emerging Issues. International Institute for Environment and Development, Sustainable Markets Discussion Paper Number 2. London, 2006.

Echols, Marsha, Biofuels Certification and the Law of the World Trade Organization. ICTSD Programme on Agricultural Trade and Sustainable Development, Geneva, 2009.

Food and Agriculture Organization of the United Nations, Global Forest Resources Assessment 2010. FAO Forestry Paper 163.

Food and Agriculture Organization of the United Nations, The State of Food and Agriculture FAO, Rome, 2008.

Fritsche, Uwe, Katja Hunecke, Andreas Hermann, Falk Schulze and Kirsten Wiegmann Sustainability Standards for Bioenergy. WWF, Frankfurt, 2006. 
Goldemberg, J. and T. Johansson, World Energy Assessment-Overview 2004 Update United Nations Development Programme, New York, 2004.

Howse, Robert, Petrus van Bork and Charlotte Hebebrand, WTO Disciplines and Biofuels: Opportunities and Constraints in the Creation of a Global Marketplace. IPC Discussion Paper, International Food and Trade Policy Council, Washington USA, 2006.

International Energy Agency, From $1^{\text {st }}$ to $2^{\text {nd }}$ Generation Biofuel Technologies: An Overview of Current Industry and R\&D Activities OECD/IEA, Paris, 2008.

International Energy Agency, Biofuels for Transport: An International Perspective International Energy Agency, Paris, 2004.

International Panel for Sustainable Resource Management, Towards Sustainable Production and Use of Resources: Accessing Biofuels United Nations Environment Programme, Paris, 2009.

Jank, Marcos, Geraldine Kutas, Luiz Fernando do Amaral and Andre Nassar, EU and U.S. Policies on Biofuels: Potential Impacts on Developing Countries. The German Marshall Fund of the United States, Washington, 2007.

Jull, Charlotta, Patricia Carmona Redondo, Victor Mosoti and Jessica Vapnek, Recent Trends in the Law and Policy of Bioenergy Production, Promotion and Use. FAO Legal Papers Online \#68, 2007.

Lewandowski, Iris and Andre Faaij, Steps Towards the Development of a Certification System for Sustainable Bio-energy Trade. Copernicus Institute of Sustainable Development and Innovation, The Netherlands, 2004.

Project Group Sustainable Production of Biomass, Criteria for Sustainable Biomass Production Energy Transition Taskforce, The Netherlands, 2006.

Rosegrant, Mark, Biofuels and Grain Prices: Impacts and Policy Responses International Food Policy Research Institute, Washington, 2008.

Schmidhubner, Josef, Biofuels: An Emerging Threat to Europe's Food Security? Impact of an Increased Biomass Use on Agricultural Markets, Prices and Food Security: A Longer-term Perspective. Notre Europe, Paris, 2007.

Sissine, Fred, Energy Independence and Security Act of 2007: A Summary of Major Provisions. Congressional Research Service, 2007.

Steenblick, Ronald, Christopher Beaton and Juan Simon, Biofuels - At What Cost? Government Support for Ethanol and Biodiesel in Switzerland: 2008 Update. International Institute for Sustainable Development, Geneva, 2008.

UFOP-Information. Germany's Biodiesel Sector Has Now to Document Its Sustainability. Union zur Förderung von Oel- und Proteinpflanzen e. V., Berlin, 2010. 
United Nations Conference on Trade and Development, Making Certification Work for Sustainable Development: The Case of Biofuels, United Nations, New York and Geneva, 2008.

Woods, Jeremy and Rocio Diaz-Chavez, The Environmental Certification of Biofuels International Transport Forum, Discussion paper No 2007-6, London, 2007.

Zarrilli, Simonetta and Jennifer Burnett, Making Certification Work for Sustainable Development: The Case of Biofuels. United Nations, New York and Geneva, 2008.

\section{Books and book chapters}

van den Bossche, Peter, The Law and Policy of the World Trade Organization: Text, Cases and Materials. Cambridge University Press, Cambridge, 2005.

\section{Newspapers and non-academic periodicals}

Harrabin, Roger "EU rethinks biofuels guidelines” BBC News 14 January 2008.

Rutz, Dominic, and Rainer Janssen "Launch of the Global-Bio-Pact project” (2010) 1 GlobalBio-Pact Newsletter 1-4.

Stearns, Jonathan EU Warns Brazil on Environmental Impact of Biofuels (Update 3). Bloomberg, 5 July 2007.

\section{Press releases}

Commission of the European Communities, Communication from the Commission: An Energy Policy for Europe. Brussels, 10.1.2007 COM(2007) 1.

Ferguson, Martin "Second Generation Biofuels Funding Announced” Australian Government Media Release 5 August 2009.

Roundtable on Sustainable Biofuels. "RSB Recognaized by the European Union as Proof of Compliance With the Renewable Energy Directive”. Press Release 19 July 2011.

\section{Conference papers}

Howard, Geoffery "Risks of invasion from biofuel feedstocks: terrestrial, freshwater and marine” Workshop on biofuel production and invasive species, Nairobi, 20-22 March 2009 


\section{APPENDIX ONE}

\section{European Renewable Energy Directive (RED)}

(a) Regulations relating to greenhouse gas savings.

The RED Article 17 states that the greenhouse gas emission saving from the use of biofuels should be at least 35 per cent, this will rise to at least 50 per cent from 2017 and 60 per cent from 2018. Article 19 sets down the method for calculating greenhouse gas emissions. This includes the use of the list of default values, the process for adding a new biofuel production pathway to the default list, and the factors to be taken into consideration in the calculations. Annex C explains the methodology used in the calculations.

The RED also specifies that changes in land use must be taken into consideration in calculating the greenhouse gas emission savings of biofuels. For example, the conversion of land with high carbon stocks in the soil or vegetation to land that is used for biofuel feedstock conversion could result in stored carbon being released into the atmosphere. In calculating the impact of land conversion on greenhouse gas emission, standard or actual values can be used. The RED states that the work of the Intergovernmental Panel on Climate Changes is the appropriate body to set such standard values (paragraphs 70-71). Further, articles 17.4 and 17.5 specifically state that biofuels should not be produced from wetlands, peatlands or continuously forested areas (of more than one hectare with trees higher than five meters and a canopy cover of more than 30 per cent, or trees able to reach those thresholds) unless evidence can be provided of greenhouse gas savings as a result of the conversion. The reference to wetlands takes into account the definition laid down in the Convention on Wetlands of International Importance, especially as Waterfowl Habitat (Ramsar Convention).

(b) Regulations relating to biodiversity

Article 17.3 specifies that biofuels should not be made from feedstocks obtained from land with high biodiversity value, namely:

- primary forest or other wooded land where there is no clearly visible indication of human activity or disturbance;

- $\quad$ areas designated by a competent authority for nature protection purposes; or areas designated by international agreements or intergovernmental organisations for the protection of rare, threatened or endangered ecosystems or species, unless there is evidence that biofuel production did not interfere with the nature protection purposes; 
- Highly biodiverse grasslands, both natural and non-natural, unless there is evidence that biofuel feedstock harvesting is necessary to preserve the grassland.

(c) Regulations relating to other environmental concerns

The European RED states that, where biofuels are made from feedstocks produced from within the European Union (EU), their production must comply with environmental requirements for agriculture including those concerning the protection of groundwater and surface water quality (paragraph 74).

There is no similar requirement for biofuels made from feedstocks produced outside the EU; however the RED encourages the development of multilateral and bilateral agreements that cover environmental concerns. In the absence of such agreements, the RED requires reporting on environmental issues. The RED references the Millennium Ecosystem Assessment for data on the conservation of ecosystem services such as watershed protection and erosion control (paragraphs 74 and 77).

(d) Regulations relating to labour and social conditions

The RED contains criteria to ensure acceptable working conditions and respect of human rights. Article 17.7 requires the EC to report on the impact of increased biofuel demand on social sustainability and land-use rights. The report must also state if each producing country has ratified and implemented the Cartagena Protocol on Biosafety and the Conventions of the International Labour Organisation, including:

- Convention concerning Forced or Compulsory Labour (No 29)

- Convention concerning Freedom of Association and Protection of the Right to Organise (No 87)

- Convention concerning the Application of the Principles of the Right to Organise and to Bargain Collectively (No 98)

- Convention concerning Equal Remuneration of Men and Women Workers for Work of Equal Value (No 100)

- Convention concerning the Abolition of Forced Labour (No 105)

- Convention concerning Discrimination in Respect of Employment and Occupation (No 111)

- Convention concerning Minimum Age for Admission to Employment (No 138) 
- Convention concerning the Prohibition and Immediate Action for the Elimination of the Worst Forms of Child Labour (No 182).

\section{German Biofuel Ordinance}

(a) Regulations relating to greenhouse gas savings.

The German Sustainability Ordinance for Biofuels is consistent with the European Directive, outlined above, in its requirements for greenhouse gas emission savings. Biofuels are only eligible for tax relief and the quota if the greenhouse gas emission savings are at least 35 per cent (rising to 50 per cent in 2017 and 60 per cent in 2018; Article 8). The method used to calculate greenhouse gas emissions is the same as that set out in the RED. The Biofuel Ordinance also sets down the same specifications regarding changes in land use as the RED, stating that biofuels should not be produced from wetlands, peatlands or continuously forested areas.

(b) Regulations relating to biodiversity

The requirements relating to the preservation of biodiverse land are the same as those set out in the RED and outlined in the section above.

(c) Regulations relating to other environmental concerns

Article 7 of the German Biofuel Ordinance specifies the domestic environmental regulations with which farmers from within the EU must comply.

\section{UK RTFO}

(a) Regulations relating to greenhouse gas savings.

The RTFO contains a requirement for suppliers to report on the greenhouse gas savings of biofuels purchased (Article 13.4). It is not yet mandatory for suppliers to meet a standard, but only to report against it and failure to report makes the supplier ineligible for RTFO certificates.

The RTFO takes a meta-standard approach in which existing standards and certification schemes can be used to demonstrate that that the requirements set out by the RTFO have been met. The RFA has set benchmarks to assess existing sustainability standards. The benchmark relating to greenhouse gas emission savings is " $\mathrm{C} 1.1$ - preservation of above and below ground carbon stocks”. 
(b) Regulations relating to biodiversity

The RTFO takes into consideration the sustainability risk of biofuels, including the risks to the conservation of biodiversity. Suppliers of biofuels into the UK must report on the area in which the feedstock was produced, and the biodiversity values and environmental sensitivities associated with that area are assessed by the RFA.

The meta-standard approach includes benchmarks in relation to biodiversity conservations, for assessing existing sustainability standards. The benchmarks are:

- C 2.1 Compliance with national laws and regulations relevant to biomass production and the area where biomass production takes place;

- C 2.2 No conversion of high biodiversity areas after 1 January 2008;

- C 2.3 Identification and conservation of important biodiversity on and around the production unit;

- 2.4 Preservation and/or improvement of surrounding landscape.

(c) Regulations relating to other environmental concerns

The RTFO takes into consideration the environmental sustainability of biofuel production, including soil conservation, sustainable water use and air quality. Suppliers of biofuels must report on the area in which the feedstock was produced, and the environmental sensitivities associated with that area are assessed by the RFA.

The meta-standard approach includes a number of benchmarks that relate to environmental concerns, for assessing existing sustainability standards.

The benchmarks that relate to soil conservation are:

- C 3.1 Compliance with national laws and regulations relevant to soil degradation and soil management

- C 3.2 Application of best practices to maintain and improve soil quality, including:
o Erosion control
o Soil nutrient balance
o Soil organic matter
o Prevention of salinisation
o Soil structure 
- C 3.3 The use of agricultural byproducts does not jeopardize the function of local uses of the byproducts, soil organic matter or soil nutrients balance.

The benchmarks that relate to sustainable water use are:

- C 4.1 Compliance with national laws and regulations relevant to contamination and depletion of water sources

- C 4.2 Application of best practices to reduce water usage and to maintain and improve water quality

The benchmarks that relate to air quality are:

- C 5.1 Compliance with national laws and regulations relevant to air emissions and burning practices

- C 5.2 No burning as part of land clearing or waste disposal.

(d) Regulations relating to labour and social conditions

The RTFO includes a number of benchmarks that relate to workers rights and working conditions, for assessing existing sustainability standards. The benchmarks that relate to working conditions are:

- C 6.1 Compliance with national laws concerning working conditions and workers rights

- C 6.2 Contracts (clear equitable and comprehensive contracts)

- C 6.3 Provision of information (workers are aware of their rights)

- C 6.4 Subcontracting

- C 6.5 Freedom to associate and Bargain

- C 6.6 Child labour

- C 6.7 Young workers (15-17)

- C 6.8 Health and Safety

- $\quad$ C 6.9 Wages

- C 6.10 Discrimination

- C 6.11 Forced labour

- C 6.12 Working hours

Additional benchmarks relating to land rights and community relations are:

- C 7.1 Land right issues

- C 7.2 Consultation and communication local stakeholders. 


\section{Swiss Mineral Oil Taxation Law}

(a) Regulations relating to greenhouse gas savings.

The Mineral Oil Taxation Law was amended in 2008 to give tax benefits to biofuels, both imported and domestically produced. The tax exemption however, only applies to biofuels which meet certain environmental and social criteria. Specifically, the amended Law states that biofuels must generate 40 per cent less greenhouse gas than gasoline, calculated on a lifecycle basis. It is considered that fuels from palm oil, soybeans and grains do not meet the required level of greenhouse gas savings (Article 19b).

(b) Regulations relating to biodiversity

The amended Swiss Mineral Oil Taxation Law specifically states that biofuels must not damage the environment in ways that are greater than the environmental damage caused by gasoline, they must not damage tropical forest or endanger biodiversity.

Article 19b also states that the requirements in relation to environmental damage and biodiversity are considered to have been met for fuels that are manufactured from waste or biogenic residues from the production or processing of agricultural and forestry products. Biofuels produced from palm oil, soybeans and grains are considered to not meet the requirements.

(c) Regulations relating to labour and social conditions

The amended Swiss Mineral Oil Taxation Law states that biofuels must be produced under socially acceptable conditions, citing the International Labour Organisation. Article 19d states that the minimum requirements for socially acceptable conditions are fulfilled if, in the feedstock cultivation and fuel production, domestic social legislation in the country of production has been met, or the fundamental conventions of the ILO have been met.

\section{USA EISA}

(a) Regulations relating to greenhouse gas savings

The definition of "renewable fuel" in the EISA includes factors on reduction of greenhouse gas emissions, and different types of biofuels are categorised according to their greenhouse gas emission savings. The categories include "conventional biofuels" which reduce greenhouse gas emissions by at least 20 per cent, "advanced biofuels and biodiesel" 
which reduce greenhouse gas emissions by at least 50 per cent, and “cellulosic biofuels" which reduce greenhouse gas emissions by at least 60 per cent.

The Environmental Protection Agency (EPA) is responsible for developing regulations for the sustainable production of renewable fuel, including regulations relating to greenhouse gas emissions. The Renewable Fuel Standard program (RFS2) sets the greenhouse gas emission thresholds, and provides the methodology for assessing greenhouse gas emissions and provides the results of assessments for feedstocks and production pathways. The RFS2 recognises that assessing the greenhouse gas emissions associated with biofuels is an evolving discipline, and the assessments will be revisited as new information becomes available.

(b) Regulations relating to biodiversity

The definition of "renewable fuel" in the EISA includes factors, not just on the types of feedstock used but also the land that renewable fuel feedstocks come from. Specifically, feedstock for renewable fuels must be grown on agricultural, non-forested land that was cleared or cultivated prior to December 2007. Although the EISA - unlike other certification schemes - does not contain regulations regarding land of high biodiversity value, one of the purposes of the land use restrictions is to prevent the loss of biodiversity. 